\author{
UNIVERSIDADE DE SÃO PAULO \\ FACULDADE DE FILOSOFIA, LETRAS E CIENCIAS HUMANAS \\ DEPARTAMENTO DE LÍNGUAS ORIENTAIS \\ PROGRAMA DE PÓS - GRADUAÇÃO EM LÍNGUA HEBRAICA, LITERATURA E \\ CULTURA JUDAICAS
}

\title{
ESTHER SZUCHMAN
}

Língua e identidade: Função da língua hebraica (segunda língua) no ensino-aprendizagem das escolas judaicas de São Paulo 
UNIVERSIDADE DE SÃO PAULO

FACULDADE DE FILOSOFIA, LETRAS E CIENCIAS HUMANAS

DEPARTAMENTO DE LÍNGUAS ORIENTAIS

PROGRAMA DE PÓS-GRADUAÇÃO EM LÍNGUA HEBRAICA, LITERATURA E

CULTURA JUDAICAS

ESTHER SZUCHMAN

Língua e identidade: Função da língua hebraica (segunda língua) no ensino-aprendizagem nas escolas judaicas de São Paulo

Tese de doutorado apresentada como requisito parcial para obtenção do grau de Doutor em Língua Hebraica, Literatura e Cultura judaica da Faculdade de Filosofia, Letras e Ciências Humanas da Universidade de São Paulo.

Versão corrigida - o exemplar original se encontra disponivel no CAPH da FFLCH

Orientadora: Prof. ${ }^{\text {a }}$ Dr. ELIANA ROSA LANGER.

São Paulo

2011 
SZUCHMAN, Esther. Língua e identidade: Função da língua hebraica (segunda língua) no ensino-aprendizagem nas escolas judaicas de São Paulo. Tese apresentada ao programa de Pós-Graduação em Língua Hebraica, Literatura e Cultura judaicas, Faculdade de Filosofia, Letras e Ciencias Humanas da Universidade de São Paulo, como parte dos requisitos necessários a obtenção do titulo de Doutor em Letras.

Aprovado em: São Paulo, de de

\section{Banca Examinadora}

Profa. Dra.Ana Zandwais Instituição: UFRGS

Profa. Dra.Mariza Eizirik Instituição: UFRGS

Profa. Dra.Marisa Grigoletto Instituição: FFLCH - USP

Profa. Dra. Ana Szpitskovski Instituição: USP 


\section{AGRADECIMENTOS}

Agradeço à Universidade de São Paulo por ter sido o meu lugar de crescimento acadêmico, incentivando-me na buca do conhecimento e no fomento do espírito crítico.

Ao Departamento de Lingua Hebraica Cultura e Literatura Judaicas da USP, pela acolhida e recepção na figura das professoras Berta Waldman, Nancy Rosenchan, Marta Topel, Suzana Schwartz, Saul Kirchbaum e Gabriel Steinberg.

À minha orientadora, Professora $\operatorname{Dr}^{\mathrm{a}}$ Eliana Rosa Langer, que desde o primeiro momento me possibilitou, com sua solidária orientação, diálogo e carinho, um aprofundamento e reflexão nesse trabalho.

À Prof ${ }^{\mathrm{a}}$. Dr ${ }^{\mathrm{a}}$. Ana Zandwais, mentora que semeou este projeto ainda na UFRGS com o meu trabalho de Mestrado sobre a condição judaica, e que ao longo do meu percurso, mesmo que de longe, me incentivou a mergulhar na rede de olhares e tramas na busca do conhecimento.

Aos meus colegas, amigos, e funcionários e aos demais que se fizeram presentes, com o apoio e ajuda quando mais me sentia fragilizada.

Aos meus alunos, que ao longo de tantos anos sempre foram fonte de estímulo, inspiração e de aprendizagem, sem eles esse trabalho não teria sido realizado.

Ao Ruben Szuchman (in memoriam), meu esposo, que com sua ausência, tem em mim mais presença, e as minhas filhas Vivian e Karine pelo amor, pela compreensão, apoio e incentivo ao longo dessa caminhada. 
A meus pais Menashe e Shulamit (in memoriam) pelo essencial de uma vida inteira.

À memória do Ruben, pelo seu amor incondicional ao longo de sua vida.

Às nossas filhas, Vivian e Karine promessa de uma vida. 


\section{EPÍGRAFE}

Langue perdue, langue méconnue, langue inconnue, langue en lieu et place d'une autre, troisième langue pure, langue fondamentale, langue de fond, langue autre, nous le savons à présent; il n'y a pas de langue maternelle, simplement quelque chose des "lointains fabuleux" qui s'inscrit dans l'oeuvre, dans un travail d'écriture toujours à côté de, pas tout à fait sur le trait, décalé, décentré.

\section{Regine Robin}

Língua perdida, língua não reconhecida, língua desconhecida, língua em um lugar e no lugar de outra, terceira língua pura, língua fundamental, língua de fundo, outra língua, agora sabemos; não existe uma língua maternal, simplesmente alguma coisa do "distante fabuloso" que se registra na obra, dentro da arte de escrever sempre ao lado, não totalmente dentro da linha, defasada, descentralizada. 


\section{RESUMO}

Este trabalho propõe-se a investigar e refletir, de uma perspectiva discursiva, a função da língua hebraica/segunda língua no processo de ensino-aprendizagem e os principais fatores que incidem neste processo de identificação/identidade, no atual contexto social-histórico da coletividade judaica de São Paulo, representada em sua heterogeneidade pelas escolas judaicas comunitárias: secular/laica e religiosa.

A partir do discurso didático-pedagógico que permeia as escolas judaicas comunitárias sobre a língua hebraica, instituída como matéria regular obrigatória na grade escolar na atualidade, visamos a analisar, através dos recortes de falas de exalunos, professores e diretores, filiações simbólicas imaginárias que constituem seus processos de identificação com a língua hebraica em sua estreita relação com a história, a memória e a linguagem.

Para tanto, em nosso gesto de análise recortamos as sequências discursivas obtidas no nosso questionário sobre identificação/identidade linguístico-cultural, a partir de posições-sujeito e da representação imaginária dos ex-alunos, professores e diretores da escola religiosa e secular/laica desdobradas em suas relações contraditórias em torno de saberes sobre língua hebraica no processo de ensino-aprendizagem.

Neste recorte específico de saberes buscamos analisar a relação do sujeito com a língua do "outro" na sociedade e na história. Colocamos em causa nessas análises a concepção de sujeito, de identificação/identidade e o ensino-aprendizagem de segundas línguas/língua estrangeira. Por fim, propomos um olhar sobre o ensino-aprendizagem da língua hebraica, evidenciando a complexidade da relação do sujeito consigo mesmo, com a língua do outro enquanto ser/estar entre línguas. Trata-se do sujeito compreendido em sua heterogeneidade e na sua contradição inerente, como também em determinações histórico-sociais e culturais permeadas pelo inconsciente e pela ideologia que lhe são próprios. Nessa perspectiva a subjetividade contemporânea se produz como um movimento na história com seus deslocamentos e determinações entre o dentro e o fora, o mesmo e o diferente, entre o outro das línguas, espaço de necessárias (re) acomodações na impossibilidade de tudo dizer.

Palavras Chave: Língua hebraica - segunda língua; identificação - identidade; ensino - aprendizagem. 


\begin{abstract}
This study aims to investigate and reflect, from a discursive perspective, upon the role of the Hebrew language as a second language on the teaching-learning process and the main factors that influence this process of identification / identity in the current socialhistorical context of the Jewish community of Sao Paulo represented in its heterogeneity by both secular and religious Jewish Community schools. We aim, from the didactic-pedagogical discourse that permeates the Jewish community schools Hebrew language teaching, which is mandatory as a regular subject in grade school today, to analyse from interviews of former students, teachers and principals, imaginary symbolic affiliations which constitute their identification processes with the Hebrew language in its close relationship to history, memory and language. To do so, in our analysis, we study the discursive sequences obtained in our questionnaire about the linguistic - cultural identity / identification, from subjectpositions and the imaginary representation of former students, teachers and principals from secular and religious schools developed in their contradictory relations around knowledge of the Hebrew language in the teaching - learning process. In this specific study of this knowledge we seek to analyze the subject's relationship to the language of the "other" in society and history. We question in these analyses the conception of subject, identification / identity and the teaching - learning of second / foreign languages. Finally, we propose to look at the teaching-learning of a second language, highlighting the complexity of the subject's relationship with themselves and with the other's language, as the act of being between languages. We view the subjects in their heterogeneity and in their inherent contradiction, as well as historical/social and cultural determinations permeated by their unconsciousness and their ideology. From this perspective, the contemporary subjectivity is produced as a movement in history with its dislocations, and determinations between the in and out, the same and the different, between the other in the languages, a space of necessary re-accommodations in the impossibility to say everything.
\end{abstract}

Keywords: Hebrew language - second language; identification - identity; teaching learning 


\section{SUMÁRIO}

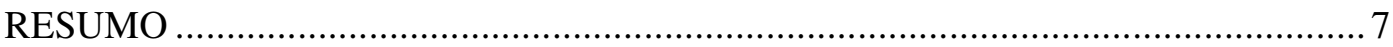

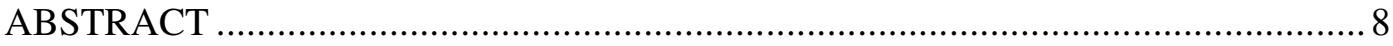

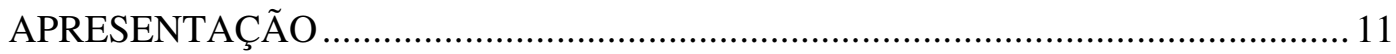

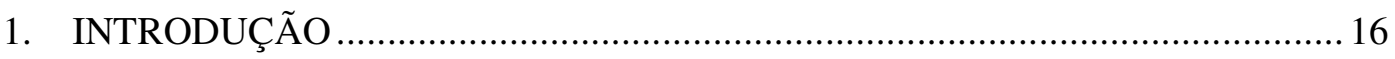

1.1. Objetivos...................................................................................................................23

1.2. Metodologia e Procedimentos de Pesquisa................................................... 24

2. DOS PRESSUPOSTOS TEÓRICOS........................................................... 27

2.1. Formação Discursiva e Formação Ideológica................................................. 28

2.2. Interdiscurso e Intradiscurso ................................................................32

2.3. O Sujeito e Subjetividade ................................................................................... 35

2.4. O Sentido ..........................................................................................43

2.5. Identidade e Alteridade........................................................................46

2.6. Memória Discursiva ..................................................................................48

2.7. Aquisição de Segunda Língua / Língua Estrangeira.....................................51

3. A LÍNGUA HEBRAICA E SEU RENASCIMENTO .......................................... 53

3.1. Percurso Histórico........................................................................................55

3.2. O Renascimento Nacional Judaico e o Idioma Nacional............................59

3.3. Entre Israel e a Diáspora .................................................................................. 64

4. CONTEXTO HISTÓRICO DA EDUCAÇÃO JUDAICA NO BRASIL ................69

4.1. Das Escolas Comunitárias de São Paulo e Suas Condições de Produção.. 84

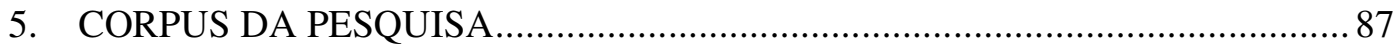

5.1. Investigando a função da língua Hebraica no processo de ensinoaprendizagem na diáspora (retomando nossos procedimentos e objetivos) 87

5.2. Primeira Seção: Professores .....................................................................90

5.3. Segunda Seção: Alunos ............................................................................998

5.3.1. Segunda Língua e a Constituição das Subjetividades .........................98 
5.3.2. O encontro-confronto de segunda língua/ língua estrangeira no processo de ensino-aprendizagem. $O$ caso do hebraico. ............................. 107

5.4. Terceira Seção: Diretores de escola ........................................................ 123

5.4.1. O estatuto da língua hebraica no processo de ensino-aprendizagem: um olhar sobre posições de sujeito: homogeneidade e heterogeneidade. 123

5.5. Da relação do político com a educação ................................................. 133

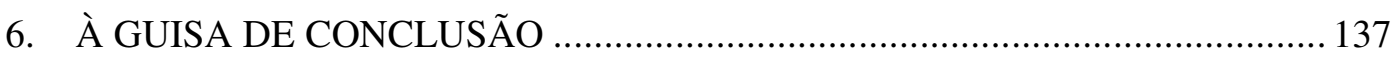

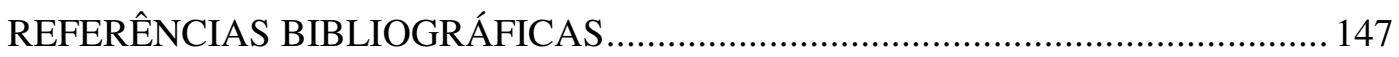

ANEXO 1 - Questionário para Professores ............................................................ 160

ANEXO 2 - Questionário para Ex-Alunos ................................................................. 161

ANEXO 3 - Questionário para Diretores ................................................................. 162

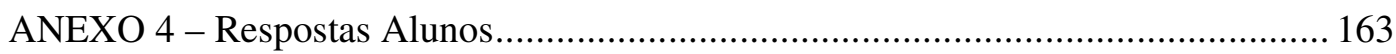

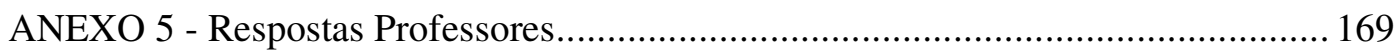




\section{APRESENTAÇÃO}

Nasci em uma família que falava a língua hebraica, assim ela se tornou a minha primeira língua, e por ter sido alfabetizada nessa língua passei a ter um íntimo contato com ela desde a infância. Meu pai, nascido em Jerusalém na Palestina sob o Império Turco Otomano cuja língua de comunicação era o árabe, desde cedo teve contato com o hebraico (língua cultural-religiosa), estudando e se aprofundando nos estudos da Torah - Bíblia Hebraica. Foi alfabetizado numa Yeshiva - academia religiosa nesta cidade, apesar de não ter sido o hebraico a língua materna de seu pai ou de sua mãe. Sua família fazia parte do velho Ishuv, antiga comunidade de judeus, que cultivavam uma ligação com a Terra de Israel calcada no desejo ancestral do povo judeu em retornar às suas raízes históricas através da volta para sua terra de origem.

Mais tarde, meu pai, sob o mandato britânico cuja língua oficial para emissão de documentos legais e de comunicação na Palestina era o Inglês, passou a integrar grupos de judeus seculares idealistas identificados com o sentimento nacional judaico (perpetrado pelo movimento sionista político) e adotou a língua hebraica como língua de uso diário. Minha mãe, de uma familia tradicional judaica, imigrou para Israel antes da criação do Estado em 1948 devido à onda de antissemitismo que varrera os países árabes do Império Otomano. A língua materna de minha mãe era o judeu-árabe, e o ladino era a língua que falava com seus avós nascidos na Turquia. Pertencentes a uma geração que nasceu sob a égide do empreendimento sionista, em casa falávamos hebraico.

\section{Acerca do nosso gesto de interpretação}

No Brasil, como professora de língua hebraica e após anos de experiência na prática de ensino em vários segmentos com adultos, adolescentes e crianças, venho-me debruçando sobre questões relativas à identificação/identidade na condição judaica, o que resultou na minha tese de Mestrado. O presente trabalho de Doutorado, na continuação deste percurso, visa aprofundar-se na relação lingua(gem) identidade e analisar a função da língua hebraica na constituição do sujeito e sentido no ensinoaprendizagem das escolas judaicas comunitárias, no atual contexto social histórico da comunidade judaica de São Paulo. 
A língua hebraica, por ter sido a minha primeira língua, permaneceu como objeto de inquietação e tem-me levado a refletir sobre os processos de identificação/ identidade em seus diferentes modos de subjetivação, de forma que encontrei na Análise de Discurso e em conceitos da psicanálise um campo profícuo para melhor entender a questão do sentido, do sujeito e do discurso em sua estreita relação com a linguagem, a memória e a identidade.

Assim, os processos discursivos em suas filiações identitárias ao ensinoaprendizagem da língua hebraica serão aqui analisados em sua relação com fatos históricos como processos simbólicos, não puramente da ordem da razão, mas da ideologia e do inconsciente. Pensamos a história, a cultura, a religião, as tradições e os costumes judaicos em sua relação com a linguagem e com os sentidos que aí se movimentam e se transformam, "escapando a qualquer norma estabelecida a priori, de um trabalho do sentido sobre o sentido, tomados no relançar indefinido das interpretações” (Pêcheux, 2002, p.51). A memória histórica não se faz pelo recurso à inflexão e as intenções, mas pelas filiações que não são produto de uma aprendizagem. (Ibidem, p. 55).

Em nossa introdução ao tema do ensino-aprendizagem nas escolas judaicas comunitárias, marcamos o lugar que ocupa atualmente a língua hebraica na área judaica, como matéria regular na grade escolar, desde a educação infantil passando pelo ensino fundamental e médio, juntamente com a história, a cultura, a filosofia e as tradições judaicas. Apontamos as dificuldades que ora se apresentam aos estudantes no ensinoaprendizagem da língua hebraica colocando em causa a denominada "crise da identidade", e o "estranhamento" da língua e cultura hebraica após anos de estudos na escola judaica. Buscamos compreender a complexidade que envolve o ensino de línguas; a designada língua materna, segunda língua/língua estrangeira e como nos relacionamos com essa alteridade; com o mundo do "outro". Buscamos, sobretudo, compreender como esses modos de subjetivação nos constituem historicamente como agentes nesse processo enquanto alunos, professores e diretores num mundo onde é cada vez mais presente a "crise da identidade" na contemporaneidade .

Para melhor nos situarmos teorica e metodologicamente, no que tange aos processos de subjetivação, abordamos noções fundamentais tais como formação 
discursiva/formação ideológica, memória discursiva, sujeito e sentido, bem como a própria alteridade na perspectiva da Análise de Discurso. Para tanto, ancoramos nossa busca em teóricos como Michel Pêcheux e J.J. Courtine e em desdobramentos que a referida teoria tem para o ensino-aprendizagem de línguas através das leituras e produções que dela têm sido feitas no Brasil (Silvana Serrani, Marisa Grigoletto e Coracini, M.J).

Em nossos pressupostos teóricos sobre a alteridade abordamos e dialogamos com escritores que analisaram o ser/estar entre línguas (característica permanente na condição judaica) dadas as determinações histórico-sociais e culturais do povo judeu face a sua trajetória de rupturas, descontinuidades e avanços (Regine Robin, Jacques Derrida e Revuz.C., entre outros).

Em nosso gesto de interpretação consideramos a formação discursiva didáticopedagógica do ensino-aprendizagem da língua hebraica enquanto uma unidade heterogênea no que tange aos diferentes modos de subjetivação que nela incidem (lugares de enunciação que constituirão os saberes específicos sobre a língua hebraica), atestada pela escola laico-secular e religiosa. Mobilizamos conceitos teóricos metodológicos da Teoria do Discurso e de identificação da psicanálise, mantendo como pressuposto básico a recusa de qualquer metalíngua universal inscrita de modo inato na mente humana e a rejeição de um sujeito intencional como origem enunciativa de seu discurso (PÊCHEUX, 1997-a, p. 311).

Para se chegar à atual realidade do ensino-aprendizagem da língua hebraica, ou seja, para analisarmos como os saberes sobre a língua se linearizaram na rede de discursos no processo de ensino-aprendizagem no atual contexto histórico, traçamos no terceiro capítulo o percurso histórico sobre a língua hebraica desde os tempos bíblicos e talmúdicos (caracterizado como o período da literatura clássica do judaismo), passando pelo renascimento nacional judaico e pela revitalização da língua hebraica no Estado de Israel e sua transformação em "low language", língua em uso em todos os setores da comunicação diária. Tecemos, sobretudo, considerações sobre as relações paradoxais que se desenvolveram entre Israel e a diáspora no atual contexto histórico-social, após o Holocausto, a criação do Estado de Israel e a situação da língua hebraica na chamada era da "Globalização".

Nessa perspectiva ainda, no quarto capítulo, rastreamos pela imprensa em ídiche e em português as condições de formação da educação judaica no Brasil, uma vez que o 
nosso corpus discursivo trata de netos de imigrantes judeus que aqui aportaram no século XX após a II Guerra Mundial. O grande surto imigratório ao Brasil começaria em 1880 e 1890 com o deslocamento de milhões de judeus da Europa Oriental ( ashkenazitas) para a Ocidental. Em consequência das ondas de pogroms ${ }^{1}$ contra os judeus na Europa Oriental e com a eclosão da I e II Guerra Mundial centenas de milhares de judeus foram deslocados, desarraigados de sua permanência centenária, tradicional dos Shetetels (aldeias) e de sua língua, o Ídiche ${ }^{2}$ (cf. Falbel, 1998, p. 15). Já a chamada imigração sefaradita, de fala espanhola ou de dialetos ladinos ibéricos, da África do Norte, da Turquia chegou ao Brasil em menor escala. A comunidade de judeus expulsos da Espanha, melhor estruturada e de nível cultural mais elevado, exerceu uma infuência dominante sobre os judeus de outras origens em várias áreas. No entanto, apesar da determinação sefaradi em manter a identidade ibérica, especialmente pela preservação do Ladino $^{3}$, houve três processos distintos de interação nos domínios otomanos: a) assimilação total dos exilados com os autóctones; b) preservação completa ou parcial da cultura dos exilados; c) infuência direta e recíproca entre os dois grupos (Cf. Harris, 1994, p. 197-199). Desde a primeira guerra mundial aos dias de hoje, o Ladino foi marcado por uma gradual modificação.

Essa massa heterogênea de imigrantes vinda ao Brasil e que tomou uma participação ativa na rede escolar judaica produziu práticas político-pedagógicas e, acima de tudo, sentidos, destinados à educação judaica a partir de 1908, data de fundação da primeira escola judaica estabelecida em Philippson, no Rio Grande do Sul, projeto da $\mathrm{JCA}^{4}$. Visto que o nosso corpus de análise se concentrou nas escolas judaicas comunitárias de São Paulo, traçamos um histórico das condições de produção de cada uma delas: as escolas de orientação secular/laica - o Colégio Renascença, a Escola Bialik, o Colégio I. L. Peretz e, o Colégio Iavne de orientação religiosa.

\footnotetext{
1 Ataque violento maciço a pessoas, com a destruição simultânea do seu ambiente (casas, negócios, centros religiosos). Historicamente, o termo tem sido usado para denominar atos em massa de violência, espontânea ou premeditada, contra judeus, protestantes, eslavos e outras minorias étnicas da Europa.

2 Segundo Weinreich (1980, p.34), o ídiche, historicamente considerada a língua dos ashkenazitas, é definido como uma língua híbrida que contém elementos do Germânico, Eslavo, Semítico e outras línguas.

3 Segundo Penny (1992), o Ladino, língua atribuída aos judeus originários da Espanha, floresceu no Império Otomano, após a expulsão dos judeus da Espanha. Os judeus acrescentaram ao romance ibérico da Espanha cristã medieval palavras portuguesas, árabes, turcas e hebraicas, além de neologismos, usando para a escrita o alfabeto hebraico.

${ }^{4}$ Jewish Colonization Association (JCA), responsável pela primeira imigração judaica organizada no Rio Grande do Sul, Brasil, em 1904: a Colônia Philippson.
} 
O último capítulo dedicado à análise do nosso corpus discursivo compreende indagações concernentes às filiações identitárias no processo de ensino-aprendizagem da língua hebraica/segunda língua, que nos constitui historicamente como sujeitos na/pela língua.

Nosso corpus discursivo autorizado pela própria postura da Análise de Discurso foi extraído de recortes produzidos a partir de depoimentos e respostas ao nosso questionário sobre subjetividade dos agentes participantes nesse processo: alunos, professores e diretores (conforme anexos no final do trabalho). Privilegiamos questões relacionadas à subjetividade dos alunos, professores e diretores em sua prática escolar acerca da relação com a língua hebraica e demais línguas estrangeiras, em suas heterogeneidades (escola secular/laica e religiosa) à formação discursiva didáticopedagógica, posto que concebemos tais questões como lugar privilegiado para configurar suas filiações à língua hebraica no atual contexto social histórico na contemporaneidade.

Em nossa análise abordamos a relação de encontro-confronto necessário na aprendizagem de segunda língua/língua estrangeira, evidenciando a complexidade da língua hebraica insepáravel do judaísmo e de suas peculiaridades. Por fim, nesse contexto em que predominam relações de saber - poder, encontram-se a educação e, portanto, o ensino-aprendizagem de línguas como um processo político mais amplo.

A fim de apreendermos relações de heterogeneidades, de aproximação e de distanciamento da língua hebraica no ensino-aprendizagem, trabalhamos na perspectiva teórica em que a identidade e identificação se processam em práticas sociais, mediante marcações simbólicas que deixam entrever posições-sujeito em movimento de identificações, produzidas discursivamente na história, enquanto fragmentos de discursos heterogêneos atravessados pela memória do dizer, marcados pela falta, pelo não-todo.

É nesse contexto que nos interessa analisar através do recorte dessas falas as filiações simbólicas imaginárias sobre a língua hebraica que se imprimem no e pelo olhar do outro, em seus processos de subjetivação, tomados enquanto redes de memória, dando lugar a uma pluralidade contraditória de filiações históricas. 


\section{INTRODUÇÃO}

As escolas israelitas comunitárias no Brasil constituem um universo de escolas judaicas geridas e mantidas pela comunidade ${ }^{5}$. Estas instituições buscam, segundo seu marco referencial predominantemente secular/laico ou religioso, viver, pensar e perpetuar os valores altos do humanismo judaico. Procuram também preparar alunos para o mundo de hoje e de amanhã, com base em um conjunto significativo de valores éticos e morais, todos fortemente alicerçados na larga tradição do judaísmo.

$\mathrm{Na}$ escola religiosa, a ênfase está pautada nos moldes da Jurisprudência judaica Halachá ${ }^{6}$, norteada pelos preceitos milenares do judaísmo, segundo as normas do Talmud $^{7}$ e de seus decodificadores. O Talmud, prática filosófica do campo teórico da $\operatorname{Torah}^{8}$, foi editado sob a forma de um longo comentário sobre a Mishna ${ }^{9}$ e tem sido objeto regular de estudo nas instituições religiosas.

Nas escolas seculares, a ênfase está pautada na pluralidade/diversidade do judaísmo pela compreensão, conhecimento e vivência das tradições, da cultura, e da liturgia judaica, evidenciando a sua atualidade e resignificação na prática de valores ético-morais que possibilitam uma integração crítica e responsável com a diversidade humana.

\footnotetext{
${ }^{5}$ As escolas comunitárias são geridas por uma mantenedora constituída, em sua maioria, por ativistas da coletividade judaica e pais que tem seus alunos matriculados nessa instituição.

6 Em hebraico, significa “caminho" ou "trilha”. Tradição legalística do judaísmo, que se confronta geralmente com a teologia, a ética, e o folclore. Decisões halachicas determinam a prática normativa, e onde há divergência, seguem a opinião da maioria dos rabinos.

${ }^{7}$ Em hebraico significa "estudo". A obra mais importante da Torá Oral (vide nota abaixo), editada sob a forma de um longo comentário em aramaico sobre seções da Mishná (vide nota abaixo). O Talmud também é conhecido pelo seu nome aramaico Guemara, que veio a ser amplamente usado para evitar críticas dos sensores cristãos do Talmud, que o apontavam como uma insensata e revoltante obra anticristã. O Talmud foi redigido numa versão palestina (Ierushalmi, literalmente "de Jerusalém” em 400 D. C., e uma versão babilônia mais autorizada (Bavli) cerca de 100 anos depois).

${ }^{8}$ Torah em hebraico significa "ensinamento". Um dos conceitos centrais do judaísmo, que pode se referir ao ensinamento judaico do Pentateuco, ou da Bíblia Hebraica, ou em seu sentido mais amplo, a toda a tradição judaica. O Pentateuco é chamado em hebraico de Chumash e conhecido como os cinco livros de Moisés. Esses livros são Bereshit (Gênese), Shemot (Êxodo), Vaikrá (Levítico) Bamidbar (Números) e Devarim (Deuteronômio)

${ }^{9}$ A Mishná trata de um conjunto de leis e decisões transmitidas oralmente de geração a geração. Em 200 D.E.C., foram coligidas, redigidas e canonizadas por Ieuda Ha - Nassi e seus discípulos. A Mishná está

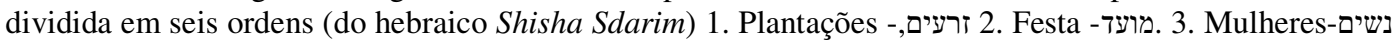
4. Danos- נזשים- 5הרות- 6. Consagrações, As ordens tratam principalmente da tradição legalística do judaísmo - Halachá - e incluem elementos de compilações da Torah Oral coligidos pelos predecessores de Judá.
} 
Nas escolas comunitárias, a educação judaica engloba estudos sobre a história judaica, língua hebraica, tradição e Torah. Nessas instituições pedagógicas, a tradição judaica, a cultura e a língua hebraica constituem o alicerce para a manutenção e continuação da identidade própria, possibilitando uma integração crítica e responsável com a sociedade.

Frequentemente é atribuído à língua hebraica um valor único e, sobretudo, próprio da identidade judaica, não se reduzindo a mesma tão somente a uma língua de alteridade $^{10}$ "Separar o judaísmo de sua vida profunda e real bem como de sua rima precisa e de suas letras quadradas é reduzi-lo ao catecismo teórico”. (LÉVINAS, 1976, p. 369).

Nessas instituições comunitárias, a língua hebraica é estudada de forma sistemática, ministrada como matéria regular no currículo escolar, sendo objeto de estudo desde a educação infantil e passando pelo ensino básico e fundamental. Vale lembrar que na escola religiosa é introduzido o ensino da filosofia judaica e da cultura judaica: Torah, Mishna e Guemara como matéria regular no ensino Fundamental e Médio.

A importância linguística do hebraico - sua coexistência com línguas vernáculas em várias épocas da história judaica e em vários lugares da diáspora - se deve a determinações histórico-sociais e culturais do povo judeu, em sua trajetória plena de rupturas, contradições, avanços, transformações e à sua continuidade como língua oficial do atual Estado de Israel. A língua hebraica esteve no "exílio" assim como o povo judeu. "A língua como a nação, não pode ter uma vida normal; entretanto, apesar de suas difíceis condições de vida, ela manteve a sua força e a sua vitalidade". (RABIN, 1973, p. 63).

Após ter sido usada por mais de 1700 anos, essencialmente como veículo de expressão literária e de orações, a língua hebraica sagrada foi laicizada e revitalizada. Como observa Agnon, (1970) As mesmas letras que foram dadas a aqueles que temiam e honravam Seu Nome, foram utilizadas para profanar tópicos igualmente sagrados. Daí em diante, os livros não mais debatiam exclusivamente normas, leis e comentários

\footnotetext{
${ }^{10}$ Referimo-nos às reflexões sobre a educação judaica apresentada por Lévinas em seu livro "Dificile Liberté". Permanecendo no plano estritamente pedagógico, Lévinas afirma ser impossível reduzir a educação judaica à instrução religiosa no sentido que é entendida pelo catolicismo ou protestantismo. A mais antiga das religiões modernas não pode ser desvinculada do conhecimento de uma língua antiga - o hebraico. E o conhecimento da língua hebraica não se adquire sem um custo. O judaísmo é inseparável do conhecimento do hebraico pelo fato de os judeus, em todas as partes, constituírem uma minoria religiosa.
} 
religiosos e éticos, e não se apresentavam mais repletos de louvores a Deus e de lamentos pelas aflições de Israel. Essas obras eram agora dedicadas também à poesia, contos, dramas ou simplesmente dedicados ao gozo mundano ${ }^{11}$. (AGNON 1970, p. 20).

A partir do século passado, com o despertar das nacionalidades, foi concedida dignidade literária às línguas vernáculas anteriormente desprezadas. "Entretanto, para o hebraico, trata-se, ao contrário, de vestir ao gosto moderno uma princesa muito altiva e adormecida há muito mais tempo que a Bela adormecida" (cf. Mirelle, H.1992:10). Cabe lembrar que a língua "sagrada hebraica" tornou-se "secular laica" já na Europa, com o movimento de Emancipação da Europa do século XIX (Haskalá - ilustração judaica) antes mesmo do empreendimento sionista, cuja representação simbólica era torná-la uma língua viva e em uso. O projeto da Haskalá iniciado por Moisés Mendelssohn, em Berlim na Alemanha, sustentava que a emancipação dos judeus, seu ajustamento intelectual e social para a população não judia deveria ser alcançado pela modernização e ocidentalização da religião e dos costumes judaicos e, sobretudo, pelo uso literário ativo da língua hebraica como expressão cultural. Em 1783, Medelssohn publicou em caracteres hebraicos sua tradução alemã do Pentateuco acompanhada de esclarecimento de cunho racionalista (biur), obra produzida por um grupo que incluía jovens intelectuais da Europa Oriental. Esse movimento "visava alinhar os judeus alemães ao standart culto da Bildung, muito embora, no inicio seu alemão fosse escrito em transliteração hebraica". (ASLANOV, 2006, p. 80).

Segundo Rabin Chaim (1997), a idéia de falar hebraico em todas as situações da vida diária, como preconizava Ben Yehuda $^{12}$, servindo de alavanca para a revitalização nacional política, foi abraçada somente por aqueles setores da comunidade judaica intelectual que adotaram a idéia de nacionalismo (assim como fizeram vários países da Europa do fim do século XIX). O sucesso da revitalização linguística em Israel deve ser atribuído principalmente aos Biluim $^{13}$ e à segunda onda migratória, composta

\footnotetext{
${ }^{11}$ Cabe aqui lembrar a recente pesquisa desenvolvida pelo prof. Saul Kirschbaum (2008) sobre a poesia secular e o idioma hebraico na Idade Média Ibérica. Segundo este pesquisador, as linhas gerais de abrangência do fenômeno da "poesia secular em hebraico" em terras árabes perdurou por dois séculos e meio (de meados do século X até o final do XII) e ainda teve fôlego para continuar produtivo por outros três séculos na Espanha cristã culminando com a expulsão em 1492. "Não apenas laico, mas muitas vezes erótico, satírico, de celebração a vida, enfim, tudo que não se esperaria de um povo tão convicto de sua sacralidade de seu idioma e tão cioso de sua vida espiritual" (Kirschbaum, 2008, p. 15)

${ }^{12}$ Expoente principal do renascimento da língua Hebraica em Israel.

13 Biluim do hebraico- Beit Yaacov lechu venelecha - "O casa de Jacó, ides e caminhemos". Nome atribuído à primeira aliyá- onda migratória a terra de Israel (1882-1903) composta principalmente por
} 
principalmente de intelectuais socialistas do Leste Europeu, que falavam a língua hebraica por razões ideológicas (ibidem 1997:366). Cabe aqui mencionar que o movimento Sionista político foi iniciado pelos judeus ashkenazitas, aqueles que se estabeleceram no norte da Europa, especialmente os da Rússia e da Polônia. Esses pioneiros que chegaram à Palestina o fizeram por uma vontade própria, por um ato de escolha moral, deliberado e sem coação, sem nenhuma necessidade econômica e sem pressão política evidente. Eram judeus ashkenazitas provenientes principalmente da Rússia e da Polônia.

Já os judeus sefaraditas (aqueles que se estabeleceram na região do Mediterrâneo, incluindo os judeus de fala Árabe), tiveram uma pequena participação no movimento Sionista político antes da Segunda Guerra Mundial. Durante os primeiros anos do Sionismo, poucos judeus falantes do árabe apoiaram de forma ativa $\mathrm{o}$ movimento Sionista (um número reduzido emigrou para a pátria judaica), enquanto outros se opuseram por alguma razão. Para a grande maioria era útil ignorar o movimento uma vez que naquela ocasião não havia nenhum conflito aparente em ser Judeu e Árabe (MYHILL, J., 2004, p. 182).

Dentre os judeus ashkenazitas, a comunidade mais importante na fundação do Estado de Israel é, sem dúvida, a dos judeus da Rússia e Polônia, que superavam os judeus da Europa ocidental tanto em número como em influência. Por circunstancias político - históricas possuíam um modo de vida independente e próprio, criando um Estado dentro do Estado, com seus ideais humanistas, sociais políticos e religiosos. Suas raízes não eram territoriais, nem geográficas e estavam embasadas em valores remanescentes da ampla tradição sobre rodas dos rolos da Torah. Com as perseguições do regime czarista e encurraladas numa espécie de gueto singular, chamado "Zona de Residência”, desenvolveram sua própria estrutura interna cultivando suas raízes religiosas e suas tradições e mantendo-se mais coesos do que as comunidades judaicas dispersas do ocidente.

As suas difíceis condições de sobrevivência, a miséria comum e o sofrimento fizeram, por um lado, com que esses judeus desenvolvessem um sentimento de fraternidade, igualdade e solidariedade entre pobres e abastados, entre os homens

judeus do Leste Europeu, influenciados pelo sionismo da Rússia. Esses pioneiros acreditavam e encorajavam a imigração e a colonização da terra através de colônias agrícolas de base cooperativa social. 
simples e influentes. Por outro lado, em resposta a forma áspera e estúpida de opressão e do despotismo mantido pelo regime czarista, na Rússia e na Polônia, os judeus assimilaram as tradições humanistas, liberais radicais e sociais - democratas da revolta intelectual perpetrada pelos elementos naqueles países. Esses judeus, antigos habitantes da "Zona de Residência", ao mesmo tempo em que preservaram seus valores tradicionais, adquiriram o credo da intelligentsia liberal (BERLIN, I. 2005:212). Acreditavam nos mesmos ideais dos revolucionários ocidentais do século XIX, na virtude humana, no conhecimento e na razão. Esses ideais fundamentados em princípios de igualdade, nas liberdades civis e nos direitos humanos, foram absorvidos pelos socialistas russos e posteriormente levados à Palestina pelos primeiros colonos, criados nos mais puros princípios do liberalismo agrário.

Com a criação do Estado de Israel, em 1948, há cerca de sessenta e quatro anos, a língua hebraica adquiriu o "status" de língua oficial do país juntamente com a língua árabe. O hebraico se tornou a língua nacional de um estado soberano, língua de produção literária filosófica, das ciências e da tecnologia de ponta. (cf. Mirelle Hadas Lebel, 1992). De todos os fatores que contribuíram para a criação de uma nação democrática e liberal em Israel na atualidade, talvez seja a língua hebraica a mais influente e comovente.

As transformações, entretanto, sofridas pela língua em Israel desde sua adoção como língua nacional e oficial do Estado, inicialmente absorvendo influências do Ídiche, Russo e do Inglês e atualmente sendo esta última "língua franca" e hegemônica no mundo, tem contribuído de forma singular no ensino-aprendizagem da língua hebraica como língua adicional na diáspora.

O conjunto de processos que ocorre atualmente em diversas esferas da vida tornou o mundo no qual vivemos uma "aldeia global" expandindo-se a uma ampla rede de atividades: na economia, política, cultura, comunicações e na linguagem (NEVO. N \& OLSHTAIN, E. 2007:8). Distâncias geográficas, antes consideradas intransponíveis, foram superadas por meio da tecnologia, possibilitando uma maior aproximação entre diversos grupos culturais. Essas transformações produziram reflexos em diversas áreas do conhecimento e, sobretudo, na linguagem. A predominante expansão do Inglês, instituída atualmente como língua franca e hegemônica, juntamente com a importância a ela atribuída para o funcionamento no mundo moderno, contribuíram para os empréstimos linguísticos de palavras e frases em ambas as modalidades escritas e 
faladas, até mesmo por línguas antes consideradas por seu isolamento, tal como o Francês (BEN-RAFAEL, 2006).

A globalização parece ser um fenômeno irreversível, um processo que nos afeta em todas as áreas do conhecimento. Para Zygmund Bauman (1999), embora as ações humanas agora se dêem em escala global, não somos capazes de ditar os conhecimentos e podemos apenas observar fronteiras se deslocando de forma veloz e imprevisível. As condições de apropriação e transmissão dos saberes nas sociedades contemporâneas transformaram-se radicalmente: a massa crescente de informações contínuas, concomitantes à refletividade e fluidez permanente, contribui com as formas inéditas de individualismo, acarretando uma fragmentação, dispersão e desengajamento que, de certa forma, bloqueiam a continuidade, o sentimento de identidade. (BAUMAN, 2000, Liquid modernity). Este autor sustenta que a globalização tanto divide como une, abrindo um fosso cada vez maior entre os que têm e os que não têm, e acrescenta que, historicamente, o homem sempre lutou para definir espaços humanos e instituições.

Pensamos que considerações que incidem em relação ao tempo, à duração, à tradição e à transmissão do saber são essenciais na compreensão das questões sociais morais e políticas das sociedades contemporâneas, caracterizadas pela fluidez em face da existência acelerada e de intensas solicitações e formas de saber ilimitadas. (cf. Haroche, C., 2004, 2005, Arendt, H., 1972, Bauman, Z., 2000). Os saberes constantemente em mutação implicam e provocam o transitório, o efêmero, o descontínuo, ou seja, a instabilidade, um conhecimento que tende por razões intrínsecas à superficialidade, à dificuldade de falta de aprofundamento, que sem dúvida tem seus reflexos na educação contemporânea e no ensino.

Os alunos das escolas judaicas comunitárias têm estudado a língua hebraica e a cultura judaica como parte de seu currículo regular durante anos importantes de sua formação. O resultado apresentado, ao finalizar o ensino fundamental ou médio, para muitos aprendizes, pais e educadores nem sempre parece ser satisfatório, considerando que ali viveram anos significantes de sua vida escolar. Os alunos demonstram, muitas vezes, uma falta básica de identificação linguístico-cultural em situações de uso efetivo dessa língua e apresentam em muitas circunstâncias um estranhamento e distanciamento no processo de ensino-aprendizagem.

Por outro lado, a língua hebraica tem sido objeto de um forte investimento nas escolas judaicas, e frequentemente, de uma forma passional. Vale a pena lembrar que é cada vez mais crescente o interesse da comunidade escolar em promover para seus 
alunos (quando as possibilidades sócio-econômicas o permitem) a realização de diversos programas de estudos e de intercâmbio em Israel, visando tanto a instrumentalização da língua hebraica, como também, um maior conhecimento da cultura judaica ${ }^{14}$.

A língua estrangeira, objeto de saber de uma aprendizagem raciocinada, é próxima e heterogênea em relação à primeira língua. Para o sujeito, a modalidade desse encontro ou confronto entre a primeira e a segunda língua, juntamente com as diversas estratégias de aprendizagem ou não, nunca é uma questão secundária. Conforme Revuz (2001:217), a língua objeto de conhecimento intelectual é também, ela própria, uma prática complexa.

O meu trabalho de Mestrado, desenvolvido entre 2003 e 2006, foi dedicado a analisar os principais fatores que incidem sobre as filiações identitárias na condição judaica, ou seja, no processo de identificação/identidade linguístico-cultural e suas relações com a história, com a memória e com a linguagem. Constatamos que, juntamente com as tradições ético-religiosas e os costumes, a língua(gem) constituiu-se um dos fatores fundamentais da heterogeneidade na condição judaica.

A atual pesquisa de doutorado será dedicada ao aprofundamento da relação língua(gem) identidade na constituição do sujeito e sentido no processo de ensinoaprendizagem. É nesse contexto da denominada "crise da identidade", onde o global se insere de maneira mais intensa e as fronteiras se tornam mais porosas que buscamos a compreensão de si e do outro. Buscamos compreender aquilo que chamamos de língua materna e de língua estrangeira. Como nos relacionamos com essas línguas e como a modalidade desse encontro nos constitui, já que o outro, o estrangeiro habita em nós, conforme Kristeva (1991), em seu livro "Etrangers à nous même”. A modalidade desse encontro vem alterar, sobretudo nossas relações de sentido, aludindo ao domínio da alteridade (cf. Robin, R., 2003:47, Pêcheux 2002:54 e Bakhtin 1979:113), uma vez que a alteridade intervém sempre. Trata-se do sujeito compreendido em sua heterogeneidade e em sua contradição inerente, e trata-se também de determinações histórico-sociais e culturais, permeadas pelo inconsciente e por ideologias que se reportam a esse sujeito.

Dessa forma, a função da língua hebraica (segunda língua) no processo de ensino-aprendizagem nas escolas judaicas comunitárias de São Paulo será objeto de

\footnotetext{
${ }^{14}$ Programas como os da Marcha da Vida oferecidos pelas escolas judaicas. Derech Eretz (caminho para Israel) do Iavne e programas do Peretz de permanência em Israel com fins de estudo e conhecimento da Cultura judaica.
} 
pesquisa no meu trabalho. Pensamos que nesse processo de ensino-aprendizagem de segunda língua, a concepção de língua, a própria aquisição, os materiais didáticos, a escola, ocupam, todos eles, um importante papel.

\subsection{Objetivos}

Esta pesquisa sobre a função da língua hebraica / segunda língua na constituição do sujeito tem como objetivo contribuir para o debate geral sobre a relação de língua(gem) e identidade, identificação linguístico-cultural, sujeito e aquisição de segunda língua. Seu principal objetivo é trazer elementos que possam contribuir para novas indagações e questionamentos suscetíveis de contribuir para todos aqueles que realizam pesquisa científica na área de ensino-aprendizagem de língua, ou, atuam na prática docente de língua estrangeira.

Esperamos contribuir com esta pesquisa para um melhor entendimento sobre a complexidade do objeto "língua" de sua prática (no relacionamento com nós mesmos, com os outros e com o mundo) e da aquisição de segunda língua - no nosso caso a língua hebraica. Nossa reflexão será pautada em conceitos contemporâneos da subjetividade e abordará elementos do debate contemporâneo sobre as noções de sujeito e subjetividade, em suas relações com as práticas da linguagem e com os processos de identificação/ identidade.

Sendo o hebraico uma das mais antigas línguas semíticas entre as religiões modernas, evidenciaremos seus recortes específicos e inseparáveis da complexidade do judaísmo, suas peculiaridades e singularidades marcadas pela heterogeneidade do povo judeu, em sua relação com a história e memória na condição judaica. Evidenciaremos a relação paradoxal em que se encontra atualmente a língua hebraica face as relações que se estabeleceram no atual contexto histórico - social entre Israel e a Diáspora judaica. Pensamos também poder contribuir para uma reflexão sobre o funcionamento da linguagem e suas possibilidades de mudança no campo do ensino-aprendizagem de línguas e da língua hebraica em particular no atual contexto social-histórico marcado pela globalização e pela homogeneização de tudo e de todos. 


\subsection{Metodologia e Procedimentos de Pesquisa.}

Através de questionários, depoimentos e entrevistas com ex- alunos, professores e diretores de escolas tratamos de permear o discurso didático-pedagógico sobre a língua hebraica nas escolas judaicas comunitárias de São Paulo: secular/laica e religiosa. Em nosso questionário privilegiamos indagações concernentes as filiações identitárias no processo de ensino-aprendizagem da língua hebraica no atual contexto escolar judaico (cf. perguntas formuladas em nossos anexos I, II, III,)

Os seguintes tópicos foram abordados em nosso questionário.

1. Subjetividade e identidade do professor de hebraico.

2. Relação do professor com línguas.

3. Subjetividade e a identidade do aluno de escola judaica.

4. Visão crítica do aluno acerca da aprendizagem da língua hebraica na escola.

5. Relação do aluno com línguas.

6. Relação da escola com línguas estrangeiras e com a língua hebraica.

7. O projeto filosófico-pedagógico proposto pela escola para o ensino de língua hebraica em sua prática escolar.

A coleta de material que nos possibilitou a extração de recortes (sequências discursivas) para o nosso corpus discursivo mobilizou uma postura própria da Análise de Discurso (AD). As sequências discursivas identificadas em função do analista são definidas por Courtine como "sequências orais ou escritas podendo, quanto à forma e a natureza dos materiais, ser eminentemente variáveis". Conforme Courtine (1981) partese de um universal discursivo entendido por Dubois (1969, apud Courtine, p. 24) como um conjunto potencial de discursos, que podem servir como objeto de análise para que se caracterize um tipo específico de discurso comportando saberes de uma FD e que se qualifica como um corpus empírico.

Em nosso questionário destacamos questões relativas à subjetividade dos alunos e dos professores em sua relação com a língua hebraica, a concepção de língua adotada pela escola e pelos professores em sua prática escolar.

Quanto ao nosso gesto de análise, pretendemos mostrar, quanto ao sujeito, a relação mundo/linguagem, em que a ordem da língua e a ordem do mundo não coincidem e só funcionam pela necessidade do imaginário, ou seja, pela ideologia. Consideramos que os sentidos não são transparentes e que devem ser pensados em seus processos históricos e sociais de constituição (ORLANDI, 1986, p. 111). Entendemos 
que cabe ao analista do discurso investigar esses efeitos de discurso, (des) construir a suposta evidência dos sentidos para que eles sejam tomados fora de sua tessitura, enquanto produto acabado e homogêneo, e reconstruir o caminho inverso pelo qual se configurou essa ilusão.

Cabe ainda ressaltar que o nosso gesto de análise e sua desconstrução não é um movimento neutro, pois depende dos gestos de leitura do analista, os quais Pêcheux denominou de gestos de leitura subjacentes à construção do próprio arquivo, enquanto trabalho da memória histórica em perpétuo confronto consigo mesmo.

Conforme Pêcheux,

Seria de maior interesse reconstruir a história desse sistema diferencial dos gestos de leitura subjacentes, na construção do arquivo, no acesso aos documentos e a maneira de apreendê-los, nas práticas silenciosas da leitura "espontânea" reconstituíveis a partir de seus efeitos na escritura: consistiria em marcar e reconhecer as evidências práticas que organizam essas leituras, mergulhando a "leitura literal" (enquanto apreensão-do-documento) numa "leitura" interpretativa - que já é uma escritura (PÊCHEUX, 1997-c, p. 57).

Tratar de entender como a matéria textual produz sentidos em AD é destacar o modo de funcionamento da linguagem, "sem esquecer que este funcionamento, não é integralmente linguístico, uma vez que dele fazem parte as condições de produção, que representam o mecanismo de situar os protagonistas e o objeto do discurso" (ORLANDI, 1996, p. 117).

Para esta autora a passagem da superfície linguística para o objeto discursivo e deste para o processo discursivo, implica atravessar as marcas linguística s em sua evidência empírica ou formal: "as marcas são construções, com efeito, de caráter ideológico" (ORLANDI, 1994, p. 304). Com esse propósito, a autora distingue entre segmentação e recorte, apontando que a passagem da segmentação para o recorte remete à noção de polissemia, efeito de sentidos, e não de linearidade informativa. A segmentação diz respeito a uma relação objetiva, positivista dos segmentos da frase, alheia à sua totalidade. $\mathrm{O}$ recorte, enquanto uma unidade discursiva considera a unidade de análise texto como um todo, diferente em natureza da soma das frases. O texto, segundo Orlandi, acolhe o processo de interação e a relação com o mundo pela (e na) linguagem. O recorte, assim considerado, é pedaço, não é segmento mensurável em sua linearidade: "é uma unidade discursiva: fragmento correlacionado de linguagem e uma situação" (ORLANDI, 1996, p. 139).

E uma vez que o recorte é um fragmento da situação discursiva em que a incompletude é pensada como algo que não se fecha (cf. Orlandi, 1996, p. 140), a 
"incompletude é a condição da linguagem, e é por ilusão que se pensa dar a palavra final". O analista de discurso não trabalha com a exaustividade em termos de esgotamento do material analisado, nem tampouco numa sequência linear ou cronológica, mas com recortes correspondentes a temáticas e aos objetivos propostos na pesquisa.

Assim, não pretendemos trabalhar com todos os depoimentos e respostas produzidas a partir de nosso questionário e que formam nosso corpus discursivo, mas sim com sequências discursivas selecionadas: recortes produzidos a partir de respostas formuladas a diretores, professores e alunos, que entendemos como representativos para a questão do ensino-aprendizagem da língua hebraica. Nossos objetivos consistem, portanto, em identificar, através de recortes dessas falas, filiações simbólicas e imaginárias, que constituem seus processos de identificação (de captura) com a língua hebraica. Quanto ao discurso didático-pedagógico das escolas será aqui considerado enquanto uma "unidade dividida, uma heterogeneidade em relação a si mesma" (COURTINE, 1982, p. 245). 


\section{DOS PRESSUPOSTOS TEÓRICOS}

Esse trabalho fundamentar-se-á principalmente em pressupostos teóricos da chamada Análise de Discurso (AD) de linha francesa, em implicações decorrentes das noções de identificação produzidas na psicanálise lacaniana e em teóricos pósestruturalistas da linguagem: autores que recusam a verdade absoluta do mundo ao cogito cartesiano, anti-positivistas. (Derrida, Kristeva e Lacan).

A Análise do Discurso tem-se constituído em uma forma de reflexão crítica à linguística, em particular, e às Ciências Sociais em geral, visto que ela se localiza no entremeio das cristalizações epistemológicas dessas ciências. A AD caracteriza-se por um viés de "ruptura" a toda uma conjuntura política e epistemológica dos anos 1960 e pela necessidade de articulação a outras áreas das ciências humanas, especialmente a linguística, o materialismo histórico, e a psicanálise. Conforme referido por Michel Pêcheux (1984):

\footnotetext{
A referência às questões filosóficas e políticas, surgidas ao longo dos anos 60 na França, constitui a base concreta, transdisciplinar de uma convergência (...) sobre a questão da construção de uma abordagem discursiva dos processos ideológicos. (PÊCHEUX, 1984, p.7).
}

Pode se afirmar que a filosofia, as ciências da linguagem e as ciências humanas e sociais em geral estavam em questão na construção desse objeto. O Discurso - um verdadeiro nó - era sem dúvida, o lugar teórico onde se imbricavam todas as grandes questões sobre a língua, a história e o sujeito.

Esse objeto teórico - o discurso - distingue-se em sua abordagem da linguística imanente, que se centra na língua nela e por ela mesma, e das demais ciências humanas e sociais onde a concepção de linguagem se reduz a um instrumento de comunicação de significações, mascarando e obscurecendo sua ligação com a prática política e, ao mesmo tempo, colocando estas ciências no prolongamento das ciências naturais. (Cf. Paul Henry 1997: 25)

Nessa abordagem considera-se $\boldsymbol{o}$ discurso como processo em suas relações com o extralinguístico, isto é o discurso como prática.

A relação crítica que a $\mathrm{AD}$ mantém com a Linguística se baseia fundamentalmente em duas correntes: o objetivismo abstrato, que considera a língua como um sistema de regras abstratas, como um objeto uno e homogêneo, e o 
subjetivismo idealista, que considera a língua como produto da individualidade em que predomina a onipotência do sujeito. (BAKTHIN, 2002, p. 72-89).

Essas considerações conduziram a $\mathrm{AD}$ a propor uma teoria não subjetiva da enunciação em que o sujeito não é dono de seu dizer, refutando as teorias da enunciação que tomam o sujeito como a fonte de seu dizer, portador de escolhas, intenções e decisões e, ao mesmo tempo a propor uma teoria discursiva da língua não como forma abstrata, mas como forma engendrada por materialidades histórico-sociais.

Partindo dessa relação de descontinuidade com a linguística, o discurso é concebido, em $\mathrm{AD}$, não como a língua, conceito geral social e histórico, nem a fala, enquanto um conceito individual, histórico e a-social. A AD sai do escopo da dicotomia clássica, a língua e a fala, o que estaria separado em Saussure. Propõe outra relação entre língua e discurso, relação que não se define pela oposição, mas pela contradição colocando no discurso o histórico e o social: (ORLANDI, 1994, p. 301). O discurso na $\mathrm{AD}$ é, sobretudo, um objeto histórico-social, onde o linguístico intervém como pressuposto.

Ao mesmo tempo a $\mathrm{AD}$ instaura uma metodologia própria, toma como unidade de análise o texto, este é considerado "não em seu aspecto extensional, mas em seu aspecto qualitativo, como unidade significativa da linguagem em uso" (ORLANDI, 1986, p. 107). Por ocupar uma relação particular entre língua e fala o discurso na AD é definido como efeito de sentidos entre locutores (PÊCHEUX, 1997-a, p. 82).

Aí se considera que o contexto, as condições de produção são constitutivos do sentido, portanto a variação é inerente ao próprio conceito de sentido. O sentido é considerado em sua condição de uso, não se limitando à sua referência estabilizada no léxico, passível de dicionarização e nem mesmo é visto como conceito estável e unívoco na língua.

Para melhor entendermos de que lugar está se falando, passamos a expor algumas noções teóricas - metodológicas para análise e reflexão sobre o processo de ensino aprendizagem de segunda língua.

\subsection{Formação Discursiva e Formação Ideológica}

O termo formação discursiva (doravante FD) aparece em 1969 com a “Arqueologia do Saber", exterior ao domínio da AD, nos trabalhos de Michel Foucault, 
dentro da vasta e fecunda interrogação sobre as condições, histórica e discursiva, nas quais se constituem os sistemas do saber.

A grande questão para Foucault nessa obra é como descrever relações entre enunciados que se agrupam provisoriamente formando "grandes famílias" designadas como " $a$ medicina", " $a$ gramática" ou " $a$ economia política", por exemplo. O autor usa a palavra arqueologia descrevendo-a como perigosa, uma vez que parece evocar rastros caídos fora do tempo e petrificados em seu mutismo.

Daí sua preocupação em como descrever discursos, buscar sua unidade dentro das histórias das idéias, do pensamento, das ciências ou dos conhecimentos.

Foucault percebe que entre as relações de enunciados há séries lacunares e emaranhados, desvios, jogos de diferença, de desvios, etc. Conclui que em lugar de "reconstituir cadeias de inferência (como se faz frequentemente na história das ciências ou da filosofia), em lugar de estabelecer quadros de diferenças (como fazem os linguistas), descreveria sistemas de dispersão". Foucault propõe que se trabalhe justamente sobre a dispersão, buscando aí uma regularidade e descrevendo sistemas de dispersão. Elabora assim a noção de Formação Discursiva.

\footnotetext{
No caso em que se puder descrever, entre certo número de enunciados, semelhante sistema de dispersão, e no caso em que entre os objetos, os tipos de enunciação, os conceitos, as escolhas temáticas, se puder definir uma regularidade (uma ordem, correlações, posições e funcionamentos, transformações), diremos, por convenção, que se trata de uma formação discursiva (FOUCAULT, 1995, p. 43).
}

Pode-se dizer que para Foucault regularidade é o termo básico para se definir formação discursiva, obtida através de regras de formação que são as "condições de existência (mas também de coexistência, de manutenção e de desaparecimento)" a que estão submetidos os elementos dessa repartição (objetos, modalidades de enunciação, conceitos, escolhas temáticas).

As regras de formação permitem dessa forma a determinação dos elementos que compõem o discurso e, consequentemente, determinam uma formação discursiva regida pelo princípio da dispersão e da repartição.

Para Foucault, um enunciado pertence a uma FD, assim como uma frase pertence ao texto. Dessa forma, a regularidade dos enunciados é definida pela FD e um conjunto de enunciados apoiados numa mesma FD constitui o que o autor chamou de discurso. 
Para Foucault, as diversas modalidades de enunciados manifestam sua dispersão em lugar de remeterem à síntese ou à função unificante de um sujeito.

O discurso assim concebido, não é a manifestação, majestosamente desenvolvida, de um sujeito que pensa que conhece, e que o diz: é, ao contrário, um conjunto em que podem ser determinadas a dispersão e sua descontinuidade em relação a si mesmo. (1995, p. 61-62).

Desse modo, Foucault (op.cit) concebe o discurso como dispersão e a FD como sendo um sistema enunciativo geral, ao qual estão submetidas as regras de formação e que vai definir o tipo de um discurso. Pensando nessa rede de formulações - enunciados, sistema de dispersão, regras de formação, FD e discurso, Foucault entende por prática discursiva:

...um conjunto de regras anônimas, históricas, sempre determinadas no tempo e no espaço, que definiram, em uma dada época e para uma determinada área social, econômica, geográfica ou linguística, as condições de exercício da função enunciativa (1995, p. 136).

Pêcheux e Fuchs (1997) retomam a noção de FD ao elaborarem o quadro epistemológico da $\mathrm{AD}$ e o fazem a partir do conceito de formação ideológica, (doravante FI), que, segundo os autores, é o elemento susceptível de intervir como uma força confrontada a outras forças na conjuntura ideológica característica de uma formação social.

Falaremos de uma formação ideológica para caracterizar um elemento (este aspecto da luta nos aparelhos) susceptível de intervir como uma força em confronto com outras forças na conjuntura ideológica, característica de uma formação social em dado momento; desse modo, cada formação ideológica constitui um conjunto complexo de atitudes e representações que não são nem 'individuais' nem 'universais' mas se relacionam mais ou menos diretamente a posições de classes em conflito umas com as outras (PECCHEUX e FUCHS, 1997, p. 166).

Nesse quadro epistemológico a partir da teoria do discurso, a espécie discursiva na AD passa a pertencer ao gênero ideológico "como um dos aspectos materiais do que chamamos de materialidade ideológica“, ou seja, as FI comportam-se necessariamente, como um de seus componentes, uma ou várias formações discursivas interligadas que determinam o que pode e deve ser dito. É justamente por essa relação necessária à formação ideológica que a FD é reformulada como aquilo que numa formação ideológica dada pode e deve ser dito.

Chamaremos então formação discursiva aquilo que, numa formação ideológica dada, isto é, a partir de uma posição dada, numa conjuntura dada, determinada pelo estado da luta de classes, determina o que pode e deve ser 
dito (articulado sobre a forma de uma arenga, de um sermão, de um panfleto, de uma exposição, de um programa etc). (PÊCHEUX, 1997-b, p. 160).

Ao lado dessa determinação do que pode e deve ser dito, Courtine acrescenta o que não pode e não deve ser dito. (COURTINE, 1981, p. 49). Numa FD, funcionariam, então, dois princípios: o de aceitabilidade e o da exclusão (esse aspecto será retomado mais adiante).

Retomando Althusser em "Aparelhos Ideológicos do Estado", Pêcheux e Fuchs (1997, p. 167) afirmam que "a ideologia interpela os indivíduos em sujeitos", ou seja, os indivíduos são interpelados em sujeitos falantes (em sujeitos de seu discurso) pelas formações discursivas que representam "na linguagem” as formações ideológicas que lhe são correspondentes. Isso equivale para os autores a afirmar que as palavras, expressões proposições, etc., recebem seu sentido da formação discursiva na qual são produzidas.

Consequentemente, o sentido de uma manifestação discursiva é decorrente de sua relação com determinada FD. Por outro lado, uma mesma seqüência discursiva inserida em diferentes FD produzirá sentidos diversos. Tal fato explica-se porque o sentido se constitui a partir de um sistema de relações (de substituição, paráfrases, sinonímias, etc.) que as diferentes expressões mantém entre si, no interior de cada FD, que, por sua vez, está determinada pela FI de que provém "Esses são os traços que presidem aos processos discursivos e podem ser chamados de relações de parafrasagem interiores a matriz de sentido de uma FD“. (PÊCHEUX e FUCHS, 1997, p. 169).

A partir daí afirmam os autores que uma palavra, uma expressão ou proposição não tem um sentido que lhe seria "próprio" vinculado a sua literalidade. "O sentido de uma sequiência só é materialmente conceptível na medida em que se concebe esta seqüência como pertencente a esta ou àquela formação discursiva (o que explica que ela possa ter vários sentidos)" (Ibidem: 169).

Isso está relacionado também com as diferentes posições que o sujeito vai assumir no discurso, pois a posição que ele assume está diretamente relacionada com a FI e FD em que ele (o sujeito) está inscrito.

A FD torna-se o lugar específico da constituição dos sentidos e da identificação do sujeito, já que ela é a manifestação, no discurso, da materialidade ideológica. A noção de FD representa, na $\mathrm{AD}$, um lugar de articulação entre ideologia e discurso. A $\mathrm{AD}$ opera com a noção de FD enquanto componente da FI com a finalidade de apreender o funcionamento da ideologia na constituição do discurso. 
Com Courtine, 1981, inaugura-se um novo momento na noção de FD. Não se trata mais de um complexo de FD com dominante, mas de uma FD heterogênea, onde há lugar para o diferente, para o contraditório. São diferentes posições-sujeito no interior de uma mesma FD bem heterogênea. Cabe destacar que as fronteiras desta FD são fundamentalmente instáveis, não tendo um limite traçado definitivamente e admitindo deslocamentos. Em "Définitions d'orientations théoriques et construction de procédures em Analyse du Discours", Courtine redefine FD, dizendo que "uma FD não é só um discurso para todos, não é também a cada um seu discurso, mas deve ser pensada como dois (ou mais) discursos em um só" (1982, p. 245). Temos então a contradição como elemento constitutivo de toda FD, que é considerada heterogênea em relação a si mesma.

É nesta ultima noção de FD, apresentada por Courtine como heterogênea e com fronteiras instáveis, que a FD será considerada no processo de ensino-aprendizagem de segunda língua, de forma a abrir espaço para as contradições, para as diferentes posições sujeito e para os diferentes efeitos de sentido.

A FD está inscrita no interior do interdiscurso, o qual regula o deslocamento de

suas fronteiras. É, portanto, o conceito de Interdiscurso aliado ao intradiscurso que passo a discutir.

\subsection{Interdiscurso e Intradiscurso}

Pêcheux propõe chamar interdiscurso ao "todo complexo com dominante" das formações discursivas, o qual é submetido à lei de desigualdade-contradiçãosubordinação, caracterizando o complexo das formações ideológicas.

O autor afirma que o próprio de toda FD é dissimular, na transparência de sentido que nela se forma, a objetividade material contraditória do interdiscurso que determina essa FD como tal. Essa objetividade reside no fato de que "algo fala" (ça parle) sempre "antes, em outro lugar e independentemente", isto é, sob a dominação do complexo das formações ideológicas. (PÊCHEUX, 1997-b. p. 162)

Dessa relação do interdiscurso com a FD resultam dois efeitos: a articulação e o pré-construído. A articulação constitui o sujeito em sua relação com o sentido, de modo que ele representa, no interdiscurso, aquilo que determina a dominação da forma-sujeito (PÊCHEUX, 1997-b, p. 164). A articulação se manifesta através do discurso transverso, 
que "atravessa e põe em conexão entre si os elementos construídos pelo interdiscurso enquanto pré-construído" que fornece por assim dizer, a matéria-prima na qual o sujeito se constitui como "sujeito falante" com a formação discursiva que o assujeita. (PÊCHEUX, 1997-b, p. 167). O pré-construído corresponde ao "sempre-já-ai” da interpelação ideológica que fornece-impõe a realidade de seu sentido sob a forma da universalidade. (Ibidem, p. 164)

No interdiscurso se formam os pré-construídos e estes são articulados, isto é, linearizados como discurso-transverso no discurso. É assim que o interdiscurso exerce uma determinação sobre a FD com a qual o sujeito se identifica que o constitui como sujeito e constitui o seu discurso.

É, então, a partir do interdiscurso intricado nesse complexo das formações ideológicas que se realiza o funcionamento da ideologia, em geral como interpelação dos indivíduos em sujeitos (e, especificamente, em sujeitos de seu discurso). A ideologia fornece "a cada sujeito" sua "realidade" enquanto sistema de evidências e significações percebidas - aceitas -experimentadas.

Courtine (1981), reiterando a idéia de assujeitamento considerada por Pêcheux crucial para caracterizar o interdiscurso de uma FD, define o interdiscurso como o lugar no qual se constituem os objetos que o sujeito enunciador se apropria para fazer deles os objetos de seu discurso. As articulações entre esses objetos (o que dá coerência ao propósito do sujeito) são o que Courtine, conforme Pêcheux (1975) chama de intradiscurso da seqüência discursiva.

É, portanto, na relação entre o interdiscurso de uma FD e o intradiscurso de uma sequiência discursiva produzida por um sujeito enunciador a partir de um lugar inscrito em uma relação de lugares no seio desta $\mathrm{FD}$, que é preciso situar os processos pelos quais o sujeito falante é interpelado-assujeitado em sujeito de seu discurso (COURTINE, 1981, p.35).

Segundo Courtine é no interdiscurso (enquanto articulação contraditória da FD com as formações ideológicas) que se constitui o domínio do saber próprio das formações discursivas. O domínio do saber funciona como um princípio de aceitabilidade discursiva em relação a um conjunto de formulações determinando "aquilo que pode e deve ser dito", ao mesmo tempo em que um princípio de exclusão determina "aquilo que não pode e não deve ser dito". (COURTINE, 1981, p.49).

Dessa forma afirma: $O$ interdiscurso realiza o fechamento de uma FD, delimitando seu interior (conjunto de elementos, a saber) e seu exterior (conjunto de elementos que não pertencem ao saber da FD). Esse fechamento é fundamentalmente 
instável, pois não consiste em estabelecer um fechamento permanente, mas sim uma inscrição entre diversas FD "como uma fronteira que se desloca, em função dos embates da luta ideológica e das transformações da conjuntura histórica de uma formação social dada“. (COURTINE, 1981, p.35 e 49).

O interdiscurso está, portanto, em constante processo de reconfiguração, através do qual o saber de uma FD é conduzido, em função das posições ideológicas que esta FD representa numa conjuntura determinada, a incorporar elementos pré-construídos produzidos no exterior dela mesma, imprimindo-lhes uma redefinição, e também, suscitando-lhes seus próprios elementos, seja sob a forma de repetição, do esquecimento ou mesmo da denegação.

O interdiscurso de uma FD (constitutivamente contraditória) enquanto instância de "formação, repetição e transformação dos elementos do saber dessa FD pode ser entendido como o que regula o deslocamento de suas fronteiras" (COURTINE, 1981, p. 49).

É o interdiscurso que determina o efeito de encadeamento do pré-construído. É o puro já-dito, o interdito do discurso, isto é, a ausência, a falta, a lembrança, o esquecimento, a incompletude. Assim, trabalha a re-significação do sujeito sobre o que já foi dito o repetível, determinando os deslocamentos promovidos por este sujeito nas fronteiras de sua FD (posição-sujeito).

Formando um par indissociável com interdiscurso temos o intradiscurso, mencionado anteriormente. $\mathrm{O}$ intradiscurso refere-se à dimensão horizontal do dizer, ao fio do discurso, à dimensão linear do dizer.

Intradiscurso é o funcionamento do discurso em relação a si mesmo (o que eu digo agora, com relação ao que eu disse antes e ao que eu direi depois); portanto o conjunto dos fenômenos de "co-referência" que garantem aquilo que se pode chamar o "fio do discurso", enquanto discurso de um sujeito.

O intradiscurso é, então, enquanto "fio do discurso" do sujeito, a rigor, um efeito do interdiscurso enquanto pré-construído (inteiramente determinado como tal do exterior) sobre si mesmo, uma vez que incorpora - dissimula, no eixo sintagmático, a relação de possibilidade de substituição entre elementos como se esses tivessem um sentido literal.

O intradiscurso é, segundo Courtine (1982, p.251), o lugar onde se realiza a sequencialização dos elementos do saber, onde a desnivelação interdiscursiva dos enunciados é linearizada. Trata se de um simulacro material do interdiscurso. 
Enquanto o interdiscurso é a dimensão vertical do discurso, o intradiscurso é a dimensão horizontal. São dois conceitos que estão ligados um ao outro, formando o discurso. Nas palavras de Courtine (1982, p. 251), falar de discurso não é senão falar do plano do interdiscurso e do intradiscurso. É na articulação do plano do interdiscurso com o plano do intradiscurso que se constitui o discurso. Assim, toda característica em termos de funcionamento ou efeitos discursivos liga uma relação da dimensão vertical, onde se elabora o saber da FD à dimensão horizontal, onde os elementos do saber linearizam-se.

Conforme vimos, a FD inscreve-se no interior do interdiscurso. O sujeito está inscrito no interior de uma FD, com a qual ele se identifica. É a noção de sujeito, associada à noção de sentido, que passo a discutir.

\subsection{O Sujeito e Subjetividade}

Com a descoberta do inconsciente, a noção de sujeito sofre reformulações e, cada vez mais, critica-se a idéia de que existiria uma identidade que define o sujeito psíquico como uma idéia totalizante e que não leva em conta a multiplicidade que nos constitui. Para Freud (apud. Chnaiderman, 2001, p.49) "a consciência é parte mínima da vida psíquica”. A idéia de uma alteridade na interioridade, por ele postulada, introduziu a noção de que somos muitos. $\mathrm{O}$ ego foi por ele definido como sendo um conjunto de identificações que cada sujeito faz no decorrer de sua vida, de modo que somos portadores de varias identificações.

Segundo Chnaiderman, o conceito de identidade é polêmico dentro do âmbito da própria psicanálise. Segundo a autora: “a identidade não é um conceito freudiano, sendo desenvolvido mais a partir de analistas que desenvolveram a noção de self - conceito que busca organizar a totalidade da experiência do indivíduo, segundo o dicionário Termos e conceitos psicanalíticos ${ }^{15}$, a pessoa total do indivíduo na realidade, inclusive o próprio corpo e a própria organização psíquica: a 'própria pessoa' de alguém, em contraste com 'outras pessoas' ou objetos situados fora desse alguém” (ibidem, p. 190).

15 Burness E. Moore, M. D. Fine, Bernard D., M.D. Termos e conceitos psicanalíticos. P. A. Artes Médicas, 1992. 
A identificação na concepção freudiana é um processo de transformação efetuado no próprio seio do aparelho psíquico, fora do nosso espaço habitual e imperceptível diretamente por nossos sentidos (NASIO, 1997, p. 100).

Para Lacan (1979), o sujeito é um significante que remete a outro significante, ou um significante é o que representa o sujeito para outro significante, ou seja, o sujeito se dá a partir da linguagem. "O UM como tal é o outro", "e o Outro é o lugar da palavra $^{16,}$.

Para falar em identificação, Lacan constrói o conceito de "traço unário", suporte da diferença, aproximando-se dessa forma do conceito de língua de Saussure, para quem todo e qualquer termo só pode ter seu valor definido em oposição a todos os outros. Em Lacan, priorizar o significante é buscar o que é da ordem do sentido, aquilo que "faz buraco". O sentido passa a ser da ordem da materialidade do significante, tudo se passando enquanto escritura. Lacan designa a identificação como o nascimento de um novo lugar, a emergência de uma nova instancia psíquica que introduz a dimensão simbólica que da origem ao sujeito do inconsciente. (NASIO, 1997, p. 101)

Já a noção de sujeito em AD é concebida desde suas primeiras formulações sobre a Teoria da Análise do Discurso por uma distinção essencial entre indivíduo e sujeito. Segundo Pêcheux: "Os elementos A e B designam algo diferente da presença física de organismos humanos individuais" (GADET e HAK, 1997, p. 82).

Essa distinção conceitual entre indivíduo e sujeito trazida para AD é marcada pelas teorias de dois autores: Foucault e Althusser. O primeiro enfatiza a relação determinada do sujeito com o enunciado e o segundo marca a relação determinada do sujeito com a ideologia. Do cruzamento dessas duas teorias chega-se ao sujeito submetido "à língua e à história" que é uma questão fundamental na AD. Segundo Orlandi (2002) essa relação entre história e língua é essencial na produção de sentidos. Acrescenta a autora: "Na $\mathrm{AD}$ não é vigente a noção psicológica de sujeito empiricamente coincidente consigo mesmo".

Ele é sujeito à língua e à história, pois para se constituir, para (se) produzir sentidos ele é afetado por elas. Ele é assim determinado, pois se não sofrer os efeitos do simbólico, ou seja, se ele não se submeter à língua e à história, ele não se constitui, ele não fala, ele não produz sentidos (ORLANDI, 2002, p. 49)

\footnotetext{
${ }^{16}$ No seminário Lacan. - L 'identification, publication hors commerce: document interne à 1 'Association Freudienne Internationale et destiné à ses membres.
} 
Encontra-se em Foucault que o enunciado tem com o sujeito uma relação determinada, pois para esse autor, descrever uma formulação enquanto enunciado não consiste em analisar as relações entre o autor e o que ele disse, "mas determinar qual é a posição que pode e deve ocupar todo indivíduo para ser seu sujeito". O sujeito na perspectiva de Foucault não se reduz a uma entidade empírica, nem a uma entidade psicológica. É, antes de tudo, caracterizado como uma posição. O sujeito de um enunciado, diz o autor é "uma função vazia podendo ser exercida por indivíduos, até certos pontos, indiferentes“, assim como "um único e mesmo indivíduo pode ocupar alternadamente diferentes posições”. (FOUCAULT, 2004, p. 107).

Ainda segundo o autor, o sujeito não pode ser confundido com as marcas da primeira pessoa, nem com o autor, já que enunciados sem estas marcas também possuem sujeito, pois um texto produzido por um único autor pode apresentar vários sujeitos de enunciados. O sujeito também não é causa "origem" ou "ponto de partida" da articulação de uma frase, nem "intenção significativa" que ordena as palavras, nem um "núcleo constante", imóvel de operações manifestas num discurso. Foucault conclui que o sujeito é "um lugar determinado e vazio que pode ser ocupado por indivíduos diferentes“, um lugar que "varia" no decorrer do texto (Ibidem, p. 109).

Essa noção de sujeito como posição é retomada por Pêcheux quando ele define o discurso como "um efeito de sentidos entre os pontos A e B" e não como uma transmissão de informação e diz que esses pontos não se referem a indivíduos, mas "designam lugares determinados na estrutura de uma formação social". Cada lugar é representado no discurso, isto é, presente, mas transformado como "posição" (PÊCHEUX, 1997-a, p. 82). Assim, desde o início, na AD, a posição sujeito é uma representação de um lugar no discurso.

Em Althusser (1985, p. 93) a noção de sujeito esta fundamentalmente apoiada em duas teses simultâneas:

1. Só há prática, através de e sob uma ideologia.

2. Só há ideologia pelo sujeito e para o sujeito.

A diferença entre indivíduo e sujeito está justamente marcada na relação com a ideologia, pois é a ideologia que faz com que um indivíduo se torne um sujeito. Althusser afirma que toda ideologia interpela os indivíduos concretos enquanto sujeitos concretos através do funcionamento da categoria de sujeito. Acrescenta que a ideologia "age" ou "funciona" de tal forma que ela "recruta" sujeitos dentre os indivíduos, ou 
"transforma" os indivíduos em sujeitos (ela os transforma a todos) através da interpelação. (ALTHUSSER, 1985, p. 96).

As funções características da ideologia são primeiramente de evidência, ou seja, de reconhecimento ideológico (evidência de que somos "sujeitos livres", de "transparência" da linguagem, etc.), sendo o desconhecimento a sua função inversa. Através desses efeitos, o indivíduo se reconhece como sujeito ao ser interpelado pela ideologia e desconhece o mecanismo da interpelação, se considerando fora dela. Dessa forma, afirma Althusser: "é um dos efeitos da ideologia a negação prática do caráter ideológico da ideologia, pela ideologia: a ideologia nunca diz eu sou ideológico". (Ibidem, p 97).

A tese da interpelação do sujeito à ideologia é retomada por Pêcheux e Fuchs que interpretam a interpelação como "assujeitamento do sujeito ideológico", que consiste no fato de que "cada um seja conduzido, sem se dar conta, e tendo a impressão de estar exercendo sua livre vontade, a ocupar o seu lugar" (PÊCHEUX e FUCHS, 1997, p. 165 - 166).

Segundo Pêcheux, é através da "identificação (do sujeito) com a formação discursiva que o domina (isto é, com a qual ele é constituído como sujeito) que a interpelação se exerce e transforma o indivíduo em sujeito de seu discurso" (1997, p. 163). Para que a interpelação se realize, afirma o autor que "o recalque inconsciente e $o$ assujeitamento ideológico estão materialmente ligados, sem estar confundidos, no interior do que se poderia designar como processo do Significante na interpelação e na identificação, processo pelo qual chamamos as condições ideológicas da reprodução/transformação das relações de produção”. (Ibidem, p. 133)

Assim, enquanto Althusser afirma que a ideologia produz dois efeitos sobre o sujeito: o de reconhecimento e desconhecimento da interpelação, na $\mathrm{AD}$, a constituição do sujeito articula entre si inconsciente (a relação com o dizer do outro) e ideologia, (a relação com a história), ou seja, como diz Pêcheux, "os processos de ‘imposição/dissimulação' que constituem o sujeito, 'situando-o' (significando para ele $o$ que ele é) e, ao mesmo tempo, dissimulando para ele essa 'situação' (esse assujeitamento) pela ilusão de autonomia constitutiva do sujeito" (Ibidem).

Dessa relação entre interpelação e inconsciente afirma Indursky que "o sujeito da Análise do Discurso é duplamente afetado: em seu funcionamento psíquico, pelo inconsciente, e em seu funcionamento social, pela ideologia". Sua interpelação em sujeito relaciona-se com o imaginário e sua estruturação como sujeito faz-se através de 
sua relação com o simbólico. E acrescenta a autora que "essas duas regiões tão diferentes em sua essência - sujeito social dotado de inconsciente - manifestam-se conjuntamente na constituição do sujeito do discurso: é interpelado, mas se acredita livre; é dotado de inconsciente, mas se percebe plenamente consciente”. (INDURSKY, 2000, p. 33).

Nesse processo funcionam dois esquecimentos, chamados de número 1 e número 2. O esquecimento número 1, cuja zona é inacessível ao sujeito por ser de natureza inconsciente, resulta do modo como somos afetados pela ideologia, ou seja, refere-se aos processos de constituição do sujeito e de seu dizer. Já o esquecimento número 2 atua quando o sujeito no discurso retoma o seu dizer para explicitar a si próprio o que disse, para aprofundar "o que pensa" e formulá-lo mais adequadamente. Esse "esquecimento" produz em nós a impressão da realidade do pensamento. "Essa impressão que é denominada ilusão referencial nos faz acreditar que há uma relação direta entre o pensamento, a linguagem e o mundo". (ORLANDI, 2002, p. 35). O esquecimento número 2 é a zona dos processos de enunciação e caracteriza-se por um processo do tipo pré-consciente/consciente (PÊCHEUX e FUCHS, 1997, p. 177).

Segundo Pêcheux, esta desigualdade entre os dois esquecimentos corresponde a uma relação de dominância de tal forma que o "esquecimento número 1 regula a relação do dito e não-dito no esquecimento número 2, onde se estrutura a seqüência discursiva, quer dizer, o não-afirmado precede e domina o afirmado“ (PÊCHEUX e FUCHS, 1997, p. 178).

Esses esquecimentos geram dois efeitos: o efeito de sujeito e o efeito de responsabilidade. $\mathrm{O}$ efeito sujeito é a ilusão de que o sujeito é sua própria origem, e origem do que ele diz, esquecendo-se do processo de que o constitui como sujeito. Esse "sempre já sujeito" se dá pelo EGO (imaginário no sujeito), que não reconhece sua subordinação, seu assujeitamento ao Outro ou ao Sujeito, “já que essa subordinaçãoassujeitamento se realiza precisamente sob a forma da autonomia". É um "processo natural e sócio-histórico pelo qual se constitui-reproduz o efeito-sujeito como interior sem exterior, e isso pela determinação do real (exterior) e especificamente do interdiscurso como real (exterior)". (PÊCHEUX, 1997-b, p. 163)

É a ilusão da autonomia que faz com que o sujeito se acredite "em total consciência e em total liberdade" e assim responsável como autor de seus atos.

$\mathrm{Na} \mathrm{AD}$, portanto, o sujeito não é visto como fonte e origem de seu dizer, mas como sendo constituído pela FD que o interpela, resgatando no seu dizer o já dito no 
interdiscurso. O sujeito é, portanto, desde sempre determinado, interpelado, constituído pela ideologia. Essa tese na AD foi formulada por Pêcheux e chamada de "teoria (não subjetiva) da subjetividade". (PÊCHEUX, 1997-b, p. 131)

Com isso podemos compreender melhor o funcionamento da forma sujeito; sujeito esse que, além de constituir-se pelo esquecimento, se constitui pela identificação com a FD que o domina, ou seja, na FD em que ele é constituído sujeito. Retomando as palavras de Pêcheux temos: "a interpelação do indivíduo em sujeito de seu discurso se realiza pela identificação (do sujeito) com a formação discursiva que o domina". (PÊCHEUX, 1997-b, p. 214)

Pêcheux afirma que a interpelação supõe necessariamente um desdobramento constitutivo de sujeito do discurso, de forma que um dos termos representa o "locutor" ou "sujeito da enunciação", o sujeito que "toma posição" com total conhecimento de causa, total responsabilidade, total liberdade etc. $\mathrm{O}$ outro termo representa "o sujeito universal, sujeito da ciência e que poderíamos dizer que é o sujeito da FD”. (Ibidem).

A relação do sujeito da enunciação com o sujeito universal da FD se dá pela forma - sujeito. É uma relação que pode representar diferentes modalidades, dentre as quais Pêcheux cita como "evidentes" o recobrimento e a contra-identificação. O recobrimento é a identificação do sujeito enunciador com o sujeito universal da FD, caracterizando o bom sujeito, isto é, o sujeito que segue a regra do que pode e deve ser dito. A "tomada de posição" do sujeito se realiza sob a forma de "livremente consentido". A contra-identificação ocorre quando o sujeito da enunciação "se volta" contra o sujeito universal por meio de uma tomada de posição que consiste em uma separação (distanciamento, contestação, questionamento, revolta...) com respeito ao que o "sujeito universal" lhe "dá a pensar", caracterizando assim o mau sujeito. (Pêcheux, 1997-b, p. 215).

A estas duas modalidades acrescenta uma terceira que funciona sob o modo da "desidentificação", isto é, de uma tomada de posição não subjetiva, que constitui um trabalho (transformação-deslocamento) da forma-sujeito e não sua pura e simples anulação (Ibidem, p.217). A respeito dessa desidentificação (e as tomadas de posição não subjetivas que delas resultam), Pêcheux afirma que paradoxalmente por um conceito de apropriação dos conceitos científicos, efetuam-se processos no qual a interpelação ideológica continua a funcionar, mas, por assim dizer, "às avessas, isto é, sobre e contra si mesma, através do 'desarranjo-rearranjo' do complexo das formações 
ideológicas (e das formações discursivas que se encontram intrincadas nesse complexo)". (PÊCHEUX, 1997-b, p. 217- 218).

Isto significa que diferentes sujeitos, relacionando-se com a forma-sujeito de uma FD podem ter diferentes posições-sujeito, o que pode gerar uma contradição interna, gerando, por sua vez, diferentes efeitos sujeito no discurso de cada um. Ou como dito por Indursky: A unicidade e a homogeneidade do sujeito ficam fortemente relativizadas, pois abre-se espaço para o trabalho na e sobre a forma-sujeito. Esse trabalho discursivo vai em dupla direção. Decorrente da contra-identificação resulta na tomada de posições não coincidentes, divergentes, discordantes. Por outro lado, $o$ trabalho na e sobre a forma sujeito decorrente da desidentificação conduz a um deslizamento de uma forma de subjetivização para outra, é a desidentificação de uma forma-sujeito e seus saberes e a decorrente identificação com uma outra forma sujeito e seu domínio de saber. (INDURSKY, 2000 p. 75).

Retomando essas reflexões sobre o sujeito ao modo de Pêcheux, Courtine (1981, p. 43) chama o sujeito universal de sujeito do saber e afirma que a posição-sujeito provém da relação do sujeito enunciador com o sujeito do saber. Courtine chama de domínio da forma-sujeito o domínio de descrição da produção do sujeito como efeito no discurso. "Isso equivale a descrever o conjunto de diferentes posições sujeito numa FD como modalidades particulares de identificação do sujeito da enunciação com o sujeito do saber, com os efeitos discursivos específicos que aí estão relacionados" (COURTINE, 1982, p. 252). Como desta relação podem surgir diferentes posições sujeito, o autor afirma que a forma-sujeito é responsável pela descrição das diferentes posições sujeito de uma FD.

Courtine reafirma Foucault ao apontar o enunciado [E] como elemento do saber próprio a uma FD, ao mesmo tempo em que lhe atribui outro estatuto. Para Courtine, $o$ enunciado consiste em um esquema geral que governa a repetibilidade no interior de uma rede de formulações. $\mathrm{O}$ autor entende por rede de formulações o conjunto estratificado (não sintagmatizado) de formulações que consiste nas formulações (reformulações) possíveis de [E]. (1981, p. 49-50).

As formulações, porém, não são, necessariamente, idênticas umas às outras: podem ser similares, também contraditórias, como no caso de duas formulações produzidas em FD diferentes. O enunciado estará presente em cada uma delas. Uma vez que as formulações podem ser produzidas simultaneamente dentro de diferentes FD, a relação entre enunciado e as formulações que o reformulam ultrapassa o limite da FD. 
Daí Courtine designar de enunciado dividido as diferentes reformulações de um enunciado, conforme a FD em que se produza a formulação que o reformula. (Ibidem, p. 102 - 103).

Trata-se, na visão de Courtine, de uma dimensão vertical e interdiscursiva, da rede de formulações capaz de reformular o enunciado não apenas no intradiscurso, numa relação horizontal, mas também numa relação vertical, no nível do interdiscurso, onde os objetos se formam como pré-construídos. Os enunciados articulam-se entre si no interior dessa rede, estabelecendo a referência dos elementos do saber de uma FD. As formações discursivas podem estabelecer entre si tanto relações de aliança como de antagonismo, por isso as formulações que nelas são produzidas e que reformulam os enunciados - formando sua rede de formulações - também podem ter entre si tipo de relações diferentes, até mesmo, antagônicas.

Courtine, ao conceber o enunciado dividido $\mathrm{P}\{\mathrm{X} / \mathrm{Y}\}$ como elemento de saber, afirma que este pode ser considerado como uma expressão que remete ao sujeito universal (SU) de uma FD. Os elementos X e Y manifestam a relação entre dois sujeitos de saber antagônicos, donde PX remete ao um sujeito universal $\mathrm{SU}_{1}$ e PY remete a um sujeito universal $\mathrm{SU}_{2}$, de tal forma que uma posição sujeito se constitui em um domínio dividido pela contradição.

Essa concepção desintagmatizada, ou seja, interdiscursiva, desnivelada, é considerada essencialmente discursiva. Na AD é designada como enunciado discursivo [E], diferenciando-se, pois, da concepção linguística de enunciado, o que nos permite dizer que a ordem do discursivo representa dois aspectos complementares: "por um lado o discursivo representa no interior do funcionamento da língua, efeitos da luta ideológica e, por outro, o discursivo manifesta a existência da materialidade linguística no interior da ideologia" (COURTINE, 1982, p.257).

Esses enunciados divididos permitem trabalhar com as diferenças. Permitem segundo Indursky: "por um lado, afirmar que a forma-sujeito abriga a diferença e a ambiguidade em seu interior de tal modo que é possível pensar esse sujeito como um sujeito dividido entre as diferentes posições de sujeito que sua interpelação ideológica lhe faculta. Por outro lado, uma forma-sujeito fragmentada abre espaço não só para os saberes de natureza semelhante, equivalente, isto é, para o parafrástico e o homogêneo, mas também cede lugar para os sentidos diferentes, divergentes, contraditórios, ou seja, para o polissêmico e o heterogêneo". (INDURSKY, 1969, p. 76). 
Em AD o sujeito é caracterizado por uma posição contraditória, marcada pela incompletude e pela diversidade, marcada pelo desejo de ser indivisível. E por ser duplamente afetado: pela ideologia e inconsciente é conduzido fatalmente a dispersão, heterogeneidade e divisibilidade. Nesse sentido pode se afirmar que, o sujeito em AD, não é totalmente livre, nem totalmente assujeitado, movendo-se entre o espaço discursivo de um e de outro, entre a incompletude e o desejo de ser completo. Para a $\mathrm{AD}$ o sujeito não é a origem do sentido tampouco elemento de onde se origina o discurso, na medida em que não existe um sujeito único, mas diversas posições sujeito, as quais estão relacionadas com determinadas formações discursivas e ideológicas.

Partindo dessa afirmação, pode-se dizer que os processos de constituição do sujeito e do sentido estão intimamente relacionados, pois no momento que o sujeito se identifica com uma determinada FD, ao mesmo tempo ele está construindo sentido(s) para este discurso.

\subsection{O Sentido}

Em $\mathrm{AD}$ a significação é tratada, pensando a relação da língua de um lado com a lalangue (o inconsciente) e, de outro, com o interdiscurso (a ideologia). Segundo Pêcheux, inconsciente e ideologia estão materialmente ligados. O sentido, assim como o sujeito, constitui-se pela interpelação ideológica, ou seja, a ideologia é a condição para a constituição do sujeito e do sentido.

A evidência do sujeito - a de que somos sempre sujeitos - apaga o fato de que o indivíduo é interpelado (assujeitado), assim como a evidência de sentido - esconde seu caráter material, a historicidade de sua construção, ou como afirma Pêcheux: a evidência de sentido mascara sob a transparência da linguagem, "o caráter material do sentido" das palavras e dos enunciados. (PÊCHEUX, 1997-b, p. 160)

Por isso rejeita-se em $\mathrm{AD}$ a noção de transparência, univocidade e universalidade do sentido bem como a existência de uma relação termo-a-termo entre pensamento linguagem e mundo, como se a relação entre palavras e coisas fosse uma relação natural, não linguístico-histórica.

Em AD:

O sentido de uma palavra, de uma expressão, de uma proposição etc., não existe em si mesmo (isto é, em sua relação transparente com a literalidade do significante), mas, ao contrario, é determinado pelas posições ideológicas que 
estão em jogo no processo sócio-histórico, no qual são produzidas (isto é, reproduzidas). (PÊCHEUX, 1997-b, p. 160).

Isso significa dizer que as palavras, expressões, etc. mudam de sentido "segundo as posições sustentadas por aqueles que as empregam" e "recebem seu sentido da formação discursiva na qual são produzidas" (Ibidem, p. 160). Disso resulta que as palavras mudam de sentido ao serem produzidas em diferentes FD, assim como palavras diferentes podem adquirir o mesmo sentido quando pronunciadas em uma mesma FD. É o que se chama em $\mathrm{AD}$ de polissemia e paráfrase. Daí considerarmos que todo o funcionamento da linguagem se assenta na tensão entre processos parafrásticos e processos polissêmicos. Pêcheux e Fuchs denominam processo discursivo ao processo de substituição e sinonímia de palavras ou expressões dentro de uma mesma FD, sem que por isso o sentido venha a ser outro. O processo discursivo faz com que surjam famílias parafrásticas que constituirão a matriz de sentido. Isto equivale dizer que é a partir da relação de paráfrase no interior do que chamamos "matriz de sentido" que se constitui o efeito de sentido inerente a formação discursiva (PÊCHEUX e FUCHS, 1997, p. 169). Acrescentam os autores: É este fato de toda seqüência pertencer necessariamente a esta ou aquela formação discursiva para que seja "dotada de sentido" (...) que o sujeito credita ser a fonte de sentido, sob a forma da retomada pelo sujeito de um sentido universal preexistente.

Como foi visto anteriormente, a FD não é isolada, ela está em relação com outras FD que constituem o seu interdiscurso. Também foi visto que a FD é o lugar da produção do sentido e que os sentidos mudam de uma FD para outra, de modo que o interdiscurso, lugar de constituição da FD, torna-se o lugar de todos os sentidos possíveis. Porém a própria FD "dissimula pela transparência de sentido que nela se constitui sua dependência com respeito ao 'todo complexo com dominante' isto é, ao interdiscurso". (PÊCHEUX, 1997-b, p. 162). Ao mesmo tempo em que o interdiscurso é oculto aos olhos do sujeito, devido à determinação que a FD exerce, é no interdiscurso que está a fonte de sentido, pois lá é o lugar da polissemia, de todos os sentidos possíveis. Em termos gerais, pode-se afirmar juntamente com Orlandi que a produção da linguagem se faz na articulação desses dois grandes processos: o parafrástico e $o$ polissêmico. Isto é, de um lado, há um retorno constante a um dizer sedimentado - a paráfrase e, de outro, há no texto uma tensão que aponta para o rompimento. A polissemia é essa força na linguagem que desloca o mesmo, o garantido, o sedimentado. Esses dois processos em seu funcionamento simultâneo são igualmente atuantes e, 
determinantes, limitam-se mutuamente. Essa é a tensão básica do discurso, tensão entre o texto e o contexto histórico-social: o conflito entre o mesmo e o diferente (ORLANDI, 1996, p.27). E acrescenta a autora: nesse jogo entre paráfrase e polissemia, entre o mesmo e o diferente que os sujeitos e os sentidos se movimentam, fazem seus percursos, (se) significam. (ORLANDI, 2002, p. 36)

Daí não se manter a univocidade a transparência a universalidade de sentido em AD. A constante elisão do componente material e o efeito de aparente transparência criam a ilusão da "evidencia da língua" que mascara a multiplicidade de sentidos.

Pêcheux (2002) ainda diz que

...todo enunciado é intrinsecamente suscetível de tornar se outro, diferente de si mesmo, se deslocar discursivamente de seu sentido para derivar para um outro. (...) Todo enunciado, toda seqüência de enunciados é, pois, linguisticamente descritível como uma série (léxico-sintaticamente determinada) de pontos de deriva possíveis, oferecendo lugar a interpretação (2002, p. 53).

Essa afirmação de Pêcheux vem ao encontro da concepção de que o sentido nunca é literal e sempre pode ser outro. Ele será estabelecido em consonância com as condições de produção, bem como com as condições sócio-históricas e ideológicas de quem (re) produz determinado sentido. São os pontos de deriva, presentes nas sequências discursivas, que nos oferecem a multiplicidade de sentidos e, consequentemente, apontam para determinados efeitos de sentido.

Sobre os sentidos possíveis enfatiza Orlandi: "pensar o sentido em sua pluralidade é admitir que não existe um sentido literal em relação aos outros sentidos, e sim efeitos de sentido que se constituiriam no uso da linguagem" (ORLANDI, 1996, p. 143). A linguagem pensada enquanto interação tem como condição a incompletude e seu espaço é intervalar. "Não há um centro, que é o sentido literal, e suas margens, que são os efeitos de sentido. Só há margens. Em determinadas condições de produção há a dominância de um deles que é a ilusão da existência desse centro". (Ibidem, 1966, p.144). A autora ainda complementa que por definição todos os sentidos são possíveis e que o "literal" é um sentido dominante que se institucionaliza como produto da história como um efeito discursivo.

O sentido é pensado em AD como uma relação determinada do sujeito com a história. Determinação aqui não significa acrescentar nuanças a um sentido já dado, e sim que o processo histórico social é constitutivo do sentido (ORLANDI, 1996, p. 27). É isso que leva a autora a afirmar que para a língua fazer sentido é preciso a história 
intervir, e com ela o equívoco, a ambiguidade, a opacidade, a espessura material do significante. (ORLANDI, 2004, p.67).

Em sua obra "As formas do silencio: no movimento dos sentidos", Orlandi retoma a noção de sentido. Afirma que compreender o que é efeito de sentidos é compreender que o sentido não está (alocado) em lugar nenhum, mas se produz nas relações: dos sujeitos, dos sentidos, e isso só é possível, já que sujeito e sentido se constituem mutuamente, pela sua inscrição no jogo das múltiplas formações discursivas. (2002, p. 20)

\subsection{Identidade e Alteridade}

Alteridade, heterogeneidade e dialogismo, constituem termos que - embora com diferenças de uso conforme o autor - questionam a unicidade do sujeito de todo o dizer, apontando para a presença do outro no dizer da ilusão do "um".

Em $\mathrm{AD}$ a heterogeneidade constitutiva é a condição de existência do dizer que não se entende como tendo "origem" no locutor que o enuncia. Eni Orlandi (2001) em seus trabalhos sobre identidade linguística escolar nos chama a atenção para o fato de que os sentidos não são algo fora do sujeito. “Ao significar nos significamos”. Sujeito e sentido se configuram ao mesmo tempo, e é nisso que consistem os processos de identificação. Esta autora enfatiza o fato de que os mecanismos de produção do sentido são também os mecanismos de produção dos sujeitos. Eles implicam, por sua vez, uma relação da língua (sistema capaz de equívoco) com a história, funcionando ideologicamente (relação necessária do simbólico com o imaginário).

Para Bakhtin a alteridade intervém sempre, é um movimento em direção ao outro, um reconhecimento de si pelo outro que tanto pode ser a sociedade como a cultura, sendo o elo a linguagem. Toda palavra serve de expressão a um em relação ao outro Através da palavra, defino-me em relação ao outro, em última análise, em relação à coletividade (...). A palavra é o território comum do locutor e do interlocutor. (BAKHTIN, 2002:113).

Je prends conscience de moi, originellment, a travers lês autres (...). A obra Les carnets $(1970$ - 1071) Tou ce que me concerne, a commencer par mon nom et qui metre dans ma conscience me vient du monde exterieur ... (BAKHTIN, 1984. p.355- 356) 
Falar do outro não é simplesmente prever a presença do outro na interlocução ou prever suas reações durante a comunicação. Falar do outro significa postular sua presença na constituição de todo e qualquer discurso e, consequentemente instituir a ideologia como constitutiva das relações sociais. Segundo Bakhtin (apud. Todorov, 1981, p. 98).

[...] Seul l'Adam mythique, abordant avec le premier discours um monde vierge et encore non dit, lê solitaire Adam, pouvait vraiment eviter absolument cette reórientation mutuelle par raport au discours d'autrui, qui se produit sur lê chemin de l'objet.

Postular a alteridade no discurso significa considerar o esfacelamento do sujeito significa o abandono da noção de sujeito cartesiano, de sujeito da racionalidade, da consciência e, portanto do controle de si mesmo e dos outros no qual se baseia a cultura ocidental. Significa pensar a pluralidade desordenada de vozes aparentemente única de qualquer individuo. Significa considerar o sujeito psicanalítico, inconsciente disperso e cindido cujo dizer está sujeito a equívocos incontrolados.

Régine Robin, ao se ocupar de escritores que produziram em línguas "estrangeiras", define a alteridade dizendo: "a alteridade é aquilo que escapa à atribuição, aquilo que não se pode definir totalmente". É o sentido que foge que excede aquilo que não pode ser dominado. [...]( Robin, 2003:47)

Para Derrida não há identidade possível assim como na há pertença à língua e da língua, pertença sempre marcada pela e na historicidade a não ser na ilusão, na promessa sempre adiada da coincidência consigo mesmo, do pertencimento imaginado (e inventado) a uma nação, a um grupo que se iguala ou assemelha aqueles que são desiguais, inassimiláveis. (DERRIDA, apud. Coracini, 2007, p. 49).

Kanavillil Rajagopalan (2001) em seu artigo "O conceito de identidade em Linguística: É chegada a hora para uma reconsideração radical?" aponta de forma radical para a necessidade de reformulação do conceito tradicional de identidade (de uma língua, de um falante de uma língua) como totalidade homogênea, estável e incorruptível, por um lado, e completamente acessível ao sujeito cognoscente, por outro, chamando a atenção dos linguistas para o alcance das implicações do multilinguismo e multiculturalismo. "A identidade individual, como algo total e estável, já não tem nenhuma utilidade prática num mundo marcado pela crescente migração de massas e pela entremesclagem cultural e étnica, numa escala sem precedentes”. Para esse autor, a identidade está ligada à idéia de interesses e está investida de ideologia. Assim, a 
construção da identidade é uma operação totalmente ideológica e em permanente estado de fluxo.

Ainda na perspectiva da discussão da identidade e suas implicações políticoideológicas, encontram-se as reflexões de Jacob Mey sobre os conceitos de etnia, identidade e língua. Enfatizando a equação identidade - língua nacional ou língua comum, Mey (2001), em seu trabalho sobre etnia, identidade étnica e língua comum, chama a atenção para a função determinante do fator econômico na formação e desagregação de comunidades étnicas e, consequentemente, no surgimento dos chamados conflitos étnicos. "Os conflitos que identificamos sob a denominação de 'raciais" ou de 'lutas étnicas', 'convulsões religiosas', 'guerras das línguas' etc. precisam ser examinados em um contexto mais amplo, qual seja, o da opressão e o da dominação". Como exemplo, lembramos a discussão travada em 1908, entre o ídiche e o hebraico na sociedade judaica, por ocasião da implementação de uma língua oficial.

Nessa perspectiva, segundo o autor, a questão da preservação das tradições etnolinguísticas é, sobretudo, uma questão de resistência às leis de globalização dos mercados, inclusive dos mercados culturais e não de preservação do direito individual, descontextualizado, de expressão linguística. Jacob Mey apresenta uma polêmica dos conceitos de etnia, identidade étnica e língua comum, em suas implicações éticas e político-ideológicas.

\subsection{Memória Discursiva}

Em $\mathrm{AD}$ a memória é pensada em relação ao discurso. E, nessa perspectiva ela é tratada como interdiscurso. Este é definido como aquilo que "fala antes, em outro lugar, independentemente" conforme Henry (1992). O saber discursivo que faz com que, ao falarmos nossas palavras, façam sentido. Não se trata da memória em sua concepção psicologista de memória individual, nem tampouco do inconsciente coletivo. Para Orlandi (1999 a, p. 64), "a memória se constitui pelo já-dito que possibilita todo dizer." Trata-se, pois, da noção de memória social inscrita no seio das práticas discursivas.

Diferentemente da memória cognitiva, que compõe fatos a partir de fragmentos, a memória discursiva se faz valer dos mesmos fragmentos, mas para, necessariamente, atribuir-lhes existência parcialmente encoberta, fazendo-se ressoar em outras situações enunciativas da mesma ou de uma nova inscrição. É nesse sentido que Foucault (2004) 
trata os enunciados sob duas perspectivas a da remanência, enquanto materialidade que lhe dá condições de permanência e da recorrência, enquanto possibilidade de repartição, liberta de laços primeiros, potencial de reformulação, redistribuirão e transformação. (FOUCAULT, 2004, p. 140-141).

Para Pêcheux (1999) pensar o papel da memória numa perspectiva discursiva é pensar “as condições (mecanismos, processos...) nas quais um acontecimento histórico (um elemento histórico descontínuo e exterior) é susceptível de vir a se inscrever na continuidade interna, no espaço potencial de coerência própria de uma memória". (Pêcheux, 1999, p. 49-50). Lembramos que na AD o constructo teórico de préconstruído proposto por Henry (1992) foi articulado por Michel Pêcheux ao de discurso transverso, para abordar o interdiscurso. O "pré-construído" é o "sempre já ai” histórico - social que fornece impõe a realidade e seu sentido, é o que fornece a matéria prima na qual o sujeito se constitui em relação a suas formações discursivas preponderantes.

Em relação ao jogo de forças que se mantém entre a repetição e regularização, (termo cunhado por Achard) sob o acontecimento discursivo, Pêcheux (1999) entende a repetição (dos itens lexicais e dos enunciados) como um efeito material que funda comutações e variações e, sobretudo, assegura ao nível da frase escrita - "o espaço da estabilidade de uma vulgata parafrástica produzida por recorrência, ou seja, por repetição literal dessa identidade material". Por outro lado diz: "essa recorrência do item ou do enunciado pode também caracterizar uma divisão da identidade material do item: sob o 'mesmo' da materialidade da palavra abre se o jogo da metáfora, como outra possibilidade de articulação discursiva" (PÊCHEUX, 1999, p. 53).

Essa repetição vertical em que a própria matéria “esburaca-se", perfura-se antes de desdobrar-se em paráfrase foi introduzida por Courtine e Marandin no colóquio de "Materialidades Discursivas ${ }^{17 "}$ de 1980. Ao tratar da memória discursiva na ordem do campo político, considerada pelos autores como uma das modalidades da memória histórica, Marandin e Courtine ${ }^{18}$ enviam as formas de repetição a duas ordens. À primeira chamam de uma repetição de elementos por extensão, elementos identificados no discurso ao se considerar um fragmento de discurso como determinado por um

\footnotetext{
${ }^{17}$ O colóquio Materialidades Discursivas foi realizado em 1980, em 24, 25,26 de Abril na Universidade Paris X em Nanterre. Articulava estudos que se relacionavam ao triplo real: da língua, história e inconsciente. Além de Courtine e Gadet participaram Bernard Conein, ligado às disciplinas sóciohistóricas, e Marandin.

${ }^{18}$ Courtine, J - Marandin, J. M. Quel oblect pour l'analyse du discurs? Matérialités Discoursives, Paris; Presses Universitaires de Lille, 1981, p. 28-29.
} 
enunciado e aí tomando lugar, uma repetição na ordem de uma memória cheia, saturada. E a segunda modalidade de repetição: "uma repetição vertical, que não é aquela da série de formulações que formam enunciados, mas o que se repete a partir disso, um não sabido, um não reconhecido e deslocado deslocando-se no enunciado" (COURTINE; MARADIN, 1981, p. 27-28).

Uma repetição, segundo os autores, que é ao mesmo tempo ausente e presente na série de formulações: "ausente porque ela funciona aí sob o modo de desconhecimento, e presente em seu efeito, uma repetição na ordem de uma memória lacunar ou com falhas ${ }^{19}$ " (COURTINE, 1999, p. 21). Esse processo de apagamento referencial, recalque, apagamento da memória histórica, deixa uma lacuna, a marca de seu desaparecimento mesmo que se coloque em jogo a materialidade na ordem do discurso. Memória e esquecimento são, portanto, indissociáveis na enunciação do campo discursivo. Memória saturada e lacunar ao mesmo tempo. Regulada por lembranças repetições, mas também esquecimentos de saberes histórico-sociais que emergem via interdiscurso, resgatando o sentido, produzindo por sua vez efeitos de sentido no discurso.

Nesse trabalho, interessa-nos refletir sobre como se instituiu a memória social da língua hebraica na história de um povo que passou a maior parte de sua vida em dispersão, sujeito a diferentes domínios de cultura. Como foi sua memória regulada, conservada, ou rompida deslocada ou restabelecida. De que modo os acontecimentos históricos - culturais em territórios tão diversos foram inscritos ou não na memória, como foram absorvidos por ela ou produziram rupturas. Em suma, como o trabalho de uma memória coletiva no seio de uma formação discursiva, permite à lembrança, a repetição, a refutação, mas também o esquecimento desses elementos de saber que são estruturantes de seu processo identitário. Sobretudo sob que formas se materializam esses saberes de memória? Buscamos, pois, refletir os efeitos de memória da língua hebraica pela dialética da anterioridade e atualização, visando apreender algo que ela sempre deixa em seus rastros ainda que lacunares.

\footnotetext{
${ }^{19}$ Conforme Courtine (1999): O chapéu de Clémentis. Observações sobre a memória e o esquecimento na enunciação do discurso político. "Ali, onde estava Clémentis, há somente o muro vazio do palácio. De Clémentis, restou apenas o chapéu de pele na cabeça de Gottwald. E é Gottwald, daqui para frente, que a história fará usar o chapéu".
} 


\subsection{Aquisição de Segunda Língua / Língua Estrangeira}

Contrapondo-se a lógica instrumental de produção da linguagem que orienta a maioria dos estudos de segunda língua, contrapondo - se a lógica da diferença e do contraste no modelo interacional comumente aceito na problematizarão de língua estrangeira entendemos que a aquisição de uma língua se produz na relação do sujeito com o simbólico (da relação consigo e com os outros).

O ensino aprendizagem de uma língua vem sempre incidir na relação do sujeito com a sua língua fundadora. A inscrição do sujeito numa língua estrangeira incide em novas vozes, novos pontos, novos questionamentos, alterando, inevitavelmente a constituição da subjetividade, modificando o sujeito. Esta constatação que se impõe desde os primeiros momentos da aprendizagem provoca com freqüencia surpresa e escândalo... podendo ser vivenciado como uma perda ou como uma descoberta de um espaço de liberdade (REVUZ, C., 2001, p. 224).

Sobre as dificuldades que normalmente aprendizes apresentam no processo de aprendizagem em línguas, Christine Revuz (2001), em seu trabalho "A língua estrangeira entre o desejo de um outro lugar e o risco do exílio", focaliza a questão da aprendizagem a partir de uma reflexão aprofundada sobre as implicações do postulado lacaniano do sujeito como um ser "em línguas". Revuz enfatiza que a aquisição de uma língua se traduz pela instauração de uma relação do sujeito com o simbólico, que é complexa e estruturante de suas relações, com os outros e com o saber. Nesse sentido, a aquisição da "língua materna", ou língua primeira, é "fundadora" da subjetividade, das identidades individuais e coletivas.

Outro fator importante, segundo a autora, é a de que a aprendizagem de uma língua estrangeira vai sempre incidir na relação, já instaurada, entre o sujeito e sua língua "fundadora". Dá-se sempre uma tomada de distância em relação a essa língua, o que coloca os sujeitos diante dos efeitos, salutares ou desastrosos, conforme o caso, da ruptura e do deslocamento provocados pelo aparecimento e um espaço de diferença. “Aprender uma língua é sempre, um pouco, tornar-se um outro".

Eni Orlandi (2001) aponta a existência de identidade linguística escolar como produto da escolaridade. Segundo a autora, a dinâmica da repetição de saberes discursivos da escola, está relacionada à produção da identidade como "movimento na história", isto é, como deslocamento de posições do sujeito que se constitui nas e pelas práticas "linguageiras" escolares. Tendo como pressupostos básicos os postulados da 
análise de discurso francesa, a autora argumenta que, nas práticas escolares de reprodução (repetição empírica) não se dão os processos identificatórios necessários à filiação do sujeito a uma memória interdiscursiva ou espaço de constituição de sentidos e de posições. Essa filiação só se daria, segundo Orlandi, quando a repetição é "histórica", isto é, quando não exclui a interpretação e os deslocamentos de sentidos, mecanismos que historicizam o discurso do aprendiz que podem contribuir para que ele ocupe a posição de autor (em contraposição a de mero reprodutor).

Dentro da também Análise de Discurso Francesa, Serrani-Infante (2001) repensa a produção de segundas línguas como uma variante de um processo mais amplo de "tomada de palavra significante", ou como inscrição do sujeito numa ordem simbólica que o produz como sujeito e que é determinada por fatores não cognitivos e não formuláveis. Em sua proposta denominada AREDA - "Análise de Ressonâncias Discursivas em Depoimentos Abertos”, os fatores específicos analisados são o da dimensão interdiscursiva da alteridade própria a uma segunda língua, e o dos processos identificatórios, como mecanismos inconscientes de "captura" do sujeito pela ordem dos traços significantes nessa segunda língua. Esses fatores são discutidos pela autora a partir de conceitos emprestados à teoria lacaniana da subjetividade. Contrapondo-se à tradicional lógica da diferença e do contraste presente em estudos sobre bilinguismo, bem como aos modelos internacionais de aquisição de segundas línguas, a autora chama a atenção para a necessidade de se focalizarem mais profundamente os fatores não cognitivos, relacionados ao sujeito do inconsciente, atuantes no processo de aquisição de segundas línguas. 


\section{A LÍNGUA HEBRAICA E SEU RENASCIMENTO}

Por cerca de 1300 anos, desde a conquista da terra de Israel até após a revolta de Bar-Kochba, (131-134, E.C.), os judeus falaram hebraico. Durante o exílio, por cerca de dezesseis séculos, passaram a falar outras línguas até o renascimento da língua hebraica há mais de 100 anos (1880). O renascimento da Língua Hebraica implica sua ressurreição como língua falada e seu uso, tanto na vida pública e na administração comunitária, como na esfera privada e familiar.

O renascimento da Língua Hebraica e sua transformação em língua moderna devem-se aos intelectuais judeus, escritores e filósofos da Diáspora que haviam participado do movimento da Ilustração Judaica iniciado no século XIX na Europa Ocidental $^{20}$. Estes homens contribuíram de forma significativa para dar à Língua Hebraica o status de língua nacional moderna. A "língua sagrada", que durante séculos serviu o povo judeu em suas preces e orações, foi laicizada e passou a ser usada como língua "cultural secular" antes mesmo de se tornar a língua de uso diário do empreendimento sionista.

A fase decisiva do Renascimento da Língua Hebraica foi sua transformação em Low-language ${ }^{21}$, isto é, sua penetração e seu uso em todas as atividades da linguagem do homem em sua rotina diária - no seio da família, no trabalho, no consumo cultural social e público. Esta fase, entretanto, só pôde ser concretizada graças à determinação dos grupos sionistas seculares, então movidos por seu entusiasmo revolucionário e a sua convicção em não hesitar na "profanação" de símbolos tradicionais-religiosos em sua nacionalização em favor do seu projeto nacional.

Em Israel a língua hebraica passou a ser a língua dominante em todos os setores da vida diária e absorveu influências de várias outras línguas tais como o Ídiche, Russo e o Árabe, estas, responsáveis pelas modificações que foram introduzidas inicialmente não somente em seu léxico como também na sua fonologia e na sintaxe. Nesse sentido como as demais línguas modernas vivas e em uso sujeitas a infinitos contatos com

\footnotetext{
${ }^{20}$ Referimo-nos a Mendelssohn (1729-1786), Weisel, N.H. (1725-1805), Iehuda Leib Gordon (18301892), Leon Pinsker (1821-1891), Mendele Mocher Sforim (1835-1917), Chaim Nachman Bialik, entre outros.

${ }^{21}$ Referimo-nos ao conceito de Diglossia, conforme designado por Ferguson (cf. 1959, 'Diglossia', World 15 , p. 325-340).
} 
outras línguas nacionais, consideramos que a língua hebraica, até os dias de hoje, encontra-se em um constante processo de hibridização ${ }^{22}$.

\subsection{Percurso Histórico}

O hebraico uma língua viva na antiga terra de Israel ocupou um lugar particularmente relevante no conjunto de escritos que os hebreus antigos e seus descendentes históricos - os judeus - produziram em língua hebraica nas diferentes épocas e lugares, bem como nas várias formas de expressão literária. Este complexo literário abrange não só as elaborações profanas como um vasto capítulo religioso, em que ocupam um lugar particularmente importante as Escrituras Sagradas; textos coligidos e designados em hebraico pelo nome de Tanach, (תנך) abreviatura de Torah, Neviim e Ketubim, isto é, Lei, Profetas e Hagiografia, ou Kitvei há-Kodesh.

A partir do Exílio da Babilônia, a língua hebraica falada na terra de Israel foi trocada pelas línguas internacionais da região: o aramaico e o grego. Os judeus da Babilônia falavam o aramaico e os do Egito falavam o grego durante o período helenístico. Outros compartilhavam com seus vizinhos o idumeu, o fenício e talvez o filisteu. Entretanto, em oposição aos seus vizinhos, os judeus da Palestina, Síria e Iraque continuaram a usar seus antigos textos hebraicos na oração e nos estudos religiosos.

Uma vez estruturado o Canôn Bíblico "Lei Escrita", começou o da "Lei Oral”, aí incluídas as coplilaçoes da Mishná e Guemará. Esta última conhecida como Talmud de Jerusalém e o Talmud da Babilônia, foi elaborada ao longo de quase um milênio (450 A.E. C a 500 D. E.C.) com atravessamentos de três ciclos distintos: Tradição Oral ou não codificada, Mishná e Talmud com variações linguísticas que vão do hebraico aramaizado Mishnaico ao aramaico hebraizado talmúdico (GUINSBURG, 1977, p. 21).

Cabe mencionar que durante sua longa e extensa vida o hebraico desenvolveu duas formas literárias sucessivas: a Bíblica e a da Mishna (aproximadamente desde o ano 200 A.E.C), sendo que os textos sagrados foram redigidos em parte no estilo bíblico, em parte no estilo da Mishna, e em parte foram escritos mesclados (principalmente em algumas das orações). (RABIN, C., 1973).

\footnotetext{
${ }^{22}$ Referimo-nos ao livro do Zucherman, G. (2003), Language contact and lexical enrichment in Israeli hebrew, NY, Macmillan.
} 
O hebraico falado prevaleceu somente na Judeia e em algumas regiões um pouco mais ao sul, próximas às cidades de Hebron. Este hebraico não era a linguagem da Bíblia. Era a linguagem que atualmente denominamos de "hebraico mischnaico" ou a “língua dos sábios". Com a destruição de Jerusalém (66- 70 E. C) e a revolta de Bar Kochba (131-134), a Judeia foi arrasada. Os judeus remanescentes, inclusive os sábios, estabeleceram-se nas planícies costeiras e na Galileia, substituindo paulatinamente a língua hebraica pelo aramaico.

O processo literário hebraico, no entanto, não se limitou ao aspecto acima descrito. Além da ação crescente de vários fatores, como confrontos e sínteses helenístico-judaicas, lutas pela independência política da Judeia e pela reformulação sócio-religiosa do Judaísmo, traduziu-se em outras manifestações, como atestam os livros excluídos da coletânea escritural e as obras sectárias de outras correntes religiosas - os chamados livros Apócrifos e Pseudepígrafos - Sefarim Chitzonim ou Ketuvim Achronim. (GUINSBURG, 1977, p. 16)

Segundo a visão tradicionalista, ambas as leis, a Escrita e a Oral, foram outorgadas a Moisés no Monte Sinai.

Estes são os estatutos e os juízos e as leis que o Eterno deu entre si e os filhos de Israel, no monte Sinai, através de Moisés. (Levítico, 26: 46).

"אלה חוקים והמשפטים והתורות, אשר נתן ה', בינו בין בנ"י ישראל בהר סיני ביד משה."

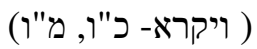

Esta visão tradicionalista concebe que toda a literatura do povo judeu se deu como uma ininterrupta corrente da tradição ${ }^{23}$ - escrita e oral (TORAH SHE'BICHTAV V'ETORAH SHE'BEALPÉ) de acordo com uma passagem clássica do Talmud em Pirkei Avot - Ética dos Pais (1:1): "MOISÉS recebeu a Torah do Sinai e a transmitiu a JOSUÉ, e Josué aos ANCIÃOS, e os anciãos aos PROFETAS, e os profetas transmitiram aos homens da GRANDE ASSEMBLEIA" ${ }^{24}$.

\footnotetext{
${ }^{23}$ Salshelet Hakabala - (שלשלת הקבלה) do hebraico a corrente da TRADIÇÃO que explica, segundo o livro Levítico, 26:46, que foram dadas leis conforme está escrito nessa passagem no plural Toroth e não Torah. Em referência à lei escrita e oral.

${ }^{24}$ A Grande Assembleia era o Sanhedrin, uma assembleia de juízes judeus que constituía a corte e legislativo supremos da antiga Israel. O Grande Sinédrio incluía um chefe ou príncipe (Nassi), um sumosacerdote (Cohen Gadol), um Av Beit Din (o segundo membro em importância) e outros 69 integrantes que se sentavam em semicírculo.
} 
Segundo a mística judaica, a língua sagrada se deu em 22 letras designadas mediante o signo "בך" - que significa "em ti”, pois está escrito: "Por ti abençoará Israel dizendo". (Gênesis, 48: 20)

Toda a tradição oral antes reunida e escrita pelos Sábios de Israel só foi compilada e organizada pelo Rabi Ieuda Hanassi, sob o nome de Mishná, no século II D.E.C. Posteriormente, outras figuras notórias agruparam o resto dos preceitos que não foram incluídos na Mishná e os classificaram em grandes volumes de livros e tratados, sob o nome de Sifrei, Sifra, Mechilta e Tosefta (acréscimos) e Midrashim (narrativas). Dado que eram muito concisos e herméticos, os discípulos e os discípulos dos discípulos os expandiram, explicaram e os interpretaram em muitos tomos do Talmud da Babilônia e de Jerusalém.

Como observa Agnon (1970), após a clausura do Talmud aceita por todo Israel, nossos sábios trataram de interpretar a Bíblia e as escrituras à luz dos segredos da língua e dos segredos de Deus, ordenando nossas orações. Compuseram canções para o Shabat e dias festivos e dessa forma tornaram-se os progenitores da moderna língua. Esses sagrados poetas foram excelsos intermediários entre Israel e Seu pai no Céu. Com o passar do tempo, entretanto, e, sobretudo, durante o longo exílio, alguns sábios já misturavam em seus livros temas sacros e laicos e "cessaram de aproveitar-se da santidade das letras e escreveram sobre temas variados", dedicando-se também à composição de poesia, dramas, contos, ou simplesmente ao gozo mundano, usando as mesmas letras anteriormente usadas por aqueles que temiam e honravam "Seu nome". (AGNON, 1970, p. 19-20).

Paralelamente ao uso do aramaico nas grandes recopilações religiosas conhecidas, como o Talmud de Jerusalém e da Babilônia, no século III até o VI D.E.C., desenvolveu-se uma vigorosa produção literária hebraica. De acordo com Rabin C. (1970), a partir do século VI, o uso escrito do hebraico espalhou-se gradativamente através das comunidades judaicas dispersas pela Ásia, África do Norte e Europa e desde aproximadamente 900 até o seu renascimento em 1880, o hebraico era usado em todas as comunidades, não somente como uma linguagem passiva de estudo e de orações, mas também para ativa comunicação, escrita em livros, documentos legais e cartas particulares. Os judeus da Inglaterra medieval (séc.XII e XIII), por exemplo, registravam em hebraico os títulos referentes a empréstimos feitos a gentios.

Durante todo esse período o hebraico era falado esporadicamente. Há relatos de judeus de países distantes que usavam o hebraico quando se encontravam e não 
dominavam em comum nenhuma outra língua. Alguns comerciantes falavam o hebraico nas feiras para não serem entendidos por seus clientes não judeus. Enquanto que os homens pios, aos sábados, falavam exclusivamente o hebraico - a língua sagrada.

A comunicação oral, por outro lado, efetuava-se normalmente na língua do país onde a pessoa vivia. Outras vezes, durante algumas gerações, falava-se a linguagem do país do qual a pessoa e seus antecessores haviam emigrado. O modo de falar dos judeus, entretanto, diferenciava-se do de seus vizinhos pelo fato de nele incluírem uma mistura de palavras hebraicas e frases hebraicas e aramaicas retiradas do Talmud. Mesmo as línguas judaicas que emergiram no período moderno da Europa, como o ídiche na Europa do Norte e o ladino (o judeu espanhol na Europa meridional e no Oriente Próximo) foram escritas e permanecem escritas paralelamente em hebraico.

Contudo, ninguém pensou em adotar a língua hebraica na linguagem cotidiana. Para Rabin isso deve ser atribuído ao fato que durante a Idade Média, a ideia política de nacionalismo e o conceito de língua nacional, usada para todas as necessidades de comunicação dentro de um grupo nacional, ainda não se haviam consolidado. (RABIN, C., 1970).

Durante a Idade Média era comum entre os povos empregar-se para fins de escrita um idioma de prestigio "clássico" que abarcava uma extensa zona idêntica à comunidade religiosa. Este é o caso do latim na Europa católica, do grego e do eslavo eclesiástico na cristandade ortodoxa, do árabe clássico no Oriente muçulmano e do sânscrito na Índia.

O hebraico, assim como outros idiomas clássicos, era estudado de acordo com suas fontes clássicas primárias, ou seja, da literatura bíblica e rabínica e era escrito imitando o idioma dessas fontes. De acordo com o tempo e o lugar, as pessoas se inclinavam a escrever, alternadamente, segundo as normas do hebraico bíblico ou Mishnaico. Durante os séculos XIII e XIV criou-se na Europa ocidental o hábito de usar o hebraico bíblico para as escritas poéticas e artísticas, ao passo que a Mishna seria usada para todo tipo de prosa.

A partir do século XVIII, a literatura hebraica na Itália, Holanda e Alemanha (especialmente em Berlim) influenciada, provavelmente, pelos temas e formas europeus puristas e classistas cultivou tanto na poesia como no drama e nas "belas letras" o estilo bíblico puro. Coube, porém, aos iluministas, à Haskalá ("Ilustração") dar os passos efetivos que abriram o caminho das luzes da razão e da secularidade e devolveram ao hebraico os sentidos terrenos do mundo e do homem. Na sua revolta contra o gueto 
medieval e contra o que consideravam subprodutos culturais (o Talmudismo, o ritualismo) e dialetais (jargão hebreu-alemão - isto é, o Ídiche, especificamente), a corrente de Moisés Mendelssohn, Weisel e seus adeptos do leste europeu dirigiram sua ideologia reformista na linguagem "nobre" da Bíblia. Outro foco de irradiação pela campanha da ilustração judaica e pela emancipação política expressou-se através dos colaboradores do primeiro periódico hebreu Há - Meassef (O Colhedor), publicado de 1783 a 1829 enquanto expressão do racionalismo germano-judeu ${ }^{25} \cdot$. Os maskilim, assim chamados, iniciaram-se maciçamente nos temas profanos das "belas letras" e submeteram-na a tratamento estético com base em padrões estilísticos e critérios de gênero, dotando-a de instrumentos próprios relevantes à modernização literária. (GUINSBURG, 1977, p. 67-70)

À medida que esta nova literatura hebraica do Iluminismo se moveu para a Europa Oriental (1820), tornou-se mais romântica. Na fase puramente racionalista do movimento, os iluministas judeus extraem da Bíblia apenas uma estilização; agora, porém, nessa segunda etapa passaram a captar a vivência lírica de um passado nacional. Em função da campanha ilustrada pela modernização do judeu e de sua integração como cidadão, os escritores maskilim desenvolvem uma produção que focaliza, em particular, as realidades da vida judaica no leste europeu. Nessa fase o puro estilo bíblico, segundo Rabin (1970), agiu como um substituto do nacionalismo judaico, pois, oprimidos pelos ghetos, dificilmente eles poderiam se expressar de outra forma. (RABIN, 1970, p. 25).

Na metade do século XIX, uma tendência realista tomou conta da literatura hebraica de forma que o estilo bíblico não era mais compatível para descrever a vida judaica moderna. A sofisticação literária e a limitação do vocabulário bíblico composto de apenas 8.000 palavras tornaram essa limitação evidente a leitores e escritores ${ }^{26}$.

A grande escola clássica da literatura hebraica moderna teve início com uma mescla livre do hebraico bíblico e da Mishna, e com misturas do aramaico do Talmud. Seu êxito deveu-se, em grande parte, ao aproximar o hebraico do idioma falado natural e também devido ao fato de que com o surgimento de um nacionalismo judeu moderno,

\footnotetext{
25 Artigos tais como "Divrei Shalom Veemet" (Palavras de Paz e Verdade) de Weisel e "Talmud Lashon Ivrit” (Ensino do Idioma hebreu) e "Otzar Shorashim” (Tesouro das raízes) de Yeudah Leib Ben Zeev (1764-1811). (GUINSBURG, 1977, p.69).

${ }^{26}$ Referimo-nos a Judah Leib Gordon (1830-1892), poeta romântico que compôs seu poema sobre a decadência da língua hebraica (Rabin, 1970, p. 25). Oh quem pode predizer o futuro... E vocês os últimos capazes de ler os meus contos.
} 
desapareceu a atitude negativa que existia frente ao judaísmo rabínico tradicional e a sua literatura.

A primeira síntese de um pensamento nacional judaico foi feita pelo iluminismo, na Galícia, através de Nachman Krochmal (1785-1845). Ele identifica na individualidade de Israel, na sua propensão religiosa e ética, as "características de uma civilização peculiar hebraica". Assim, em vez da fé e da moral reveladas por intervenção divina, a concepção da história judaica torna-se um produto histórico dos judeus como um grupo. Com isso a concepção de história judaica sofre considerável historização, secularização, e mesmo nacionalização (GUINSBURG, 1977, p. 75). Este conceito mais amplo relaciona os judeus por um princípio nacional, pois afora a religião e a ética envolve outros fatores espirituais e intelectuais dando conta de uma especificidade judaica secular e civil.

\subsection{O Renascimento Nacional Judaico e o Idioma Nacional}

O movimento que se desenvolve em torno do propósito de regenerar a vida do povo judeu, restabelecer o hebraico como língua corrente e renovar a nacionalidade

judaica em Israel tem expoentes como Leon Pinsker (1821-1891), Eliezer Ben Iehuda (1863-1932), Itzhak Peretz (1851-1915), e, em especial, Haim Nachman Bialik (18731934) e Saul Tchernikhovski (1875-1943). Enquanto o primeiro enalteceu o despertar coletivo do sentimento e da consciência nacional do judeu, o último destacou os sentidos naturais do homem no judeu como indivíduo. (GUINSBURG, 1977, p. 23).

A mudança no estilo do hebraico produziu-se de acordo com as tendências de todas as línguas mais importantes que, na segunda metade do século XIX, relegaram a um segundo plano o classicismo e aceitaram elementos provenientes de dialetos e dos novos idiomas coloquiais urbanos, de jargões técnicos e da conversação. No caso específico do hebraico, o estilo de um hebraico mais flexível e aberto ou "hebraico total" já havia sido adotado pelos escritores judeus do Leste Europeu, acostumados com o Ídiche e com a Literatura clássica do Judaísmo da Mishná.

O "hebraico total", isto é, herdeiro de todas as formas literárias: bíblico, Mishnaico, medieval e, inclusive do Ídiche, possibilitou em grande medida ao hebraico moderno a possibilidade de estabelecer sua própria estrutura de acordo com as linhas 
apropriadas para exprimir o pensamento ocidental, mantendo ao mesmo tempo os laços com o idioma e o espírito de sua grande tradição literária. (RABIN, 1970, p. 29).

O centro de gravidade do hebraico moderno deslocou-se gradativamente para Israel, a partir do início de século XX, mas somente depois de 1918 esse fato tornou-se mais palpável, não apenas porque os principais autores hebreus emigraram para lá por força das tendências e circunstâncias políticas reinantes na Europa, mas também porque a crescente comunidade judaica na Palestina passou a desempenhar um papel cada vez mais importante na vida dos judeus da diáspora com o impulso que ganhava o "Retorno de Sion", movimento conhecido como Chibat $\operatorname{Sion}^{27}$, e a renovação da colonização judaica no país com as Aliot $^{28}$. Era necessária uma língua comum para amalgamar as numerosas e diferentes comunidades que haviam se congregado na Terra Santa e ao mesmo tempo manter viva a comunicação com os judeus que permaneciam na diáspora (MEDAN, 1970, p. 38).

Expoente principal do renascimento da língua hebraica em Israel, Eliezer Ben Yehuda emigrou para a Palestina em 1881. Antes, porém, em 1879, em Viena, publicou no Hashachar ${ }^{29}$ um artigo intitulado "Um problema importante", no qual apresentava a questão do nacionalismo moderno (leumiut) como medular e o reassentamento dos judeus na Palestina como a única solução para todos os problemas do povo judeu. "Os judeus evidentemente não poderiam sobreviver como nação sem retornar à terra de seus antepassados, mas tampouco sobreviveriam como entidade nacional definida sem um idioma próprio, sem a língua de seus progenitores, a qual deveria se empregar não somente na sinagoga e nas revistas literárias, mas também para fins de comunicação cotidiana em todos os assuntos, a qualquer hora do dia ou da noite". (Ben Yehuda apud SIVAN, R., 1970, p. 34).

Em sua visão linguística, Ben Yehuda introduziu o uso do hebraico falado não somente no âmbito familiar e entre amigos, mas também iniciou o ensino da língua

\footnotetext{
${ }^{27}$ Amantes de Sion - (חיבת ציון) movimento russo que imigrou para a Palestina na década de 1880. Leon Pinsker, seu fundador, em visita à Europa ocidental criou seu famoso panfleto Autoemancipação (1882), no qual conclamava os judeus a lutar pela independência e consciência nacional para recuperar sua pátria em Eretz Israel - Terra de Israel. O livro gerou muita polêmica e inspirou Theodor Herzl em seu livro Der Judenstaat (O Estado Judeu) - a estruturar a base ideológica do movimento sionista.

${ }^{28}$ Aliot - plural de Aliá - do hebraico: imigração. Referimo-nos às ondas imigratórias, principalmente a segunda Aliá, conhecida como predominantemente político-ideológica.

${ }^{29}$ Hashachar - do hebraico: aurora. Título da publicação trimestral hebraica em Viena cujo editor era Peretz Smolenskyn, um expoente da Haskalá vienense.
} 
hebraica nas escolas, sobretudo como um idioma exclusivo nas salas de aula em que as demais matérias eram ensinadas.

Ben Yehuda lecionou na primeira escola hebraica em Jerusalém e atuou como assistente de diretor de um jornal jerusalemita. Antes de divulgar o hebraico vernáculo e cunhar novas palavras e conceitos que se faziam necessários à nova realidade, examinava as fontes clássicas do hebraico: a Bíblia, a Mishna, o Talmud, ${ }^{30}$ os Midrashim $^{31}$ e a Literatura Medieval com o objetivo de descobrir palavras que pudessem suprimir termos abandonados e esquecidos.

A ideia de falar hebraico em todas as situações da vida diária não foi instaurada sem divergências e de forma natural e pacífica. Em 1913, a chamada "guerra das línguas" irrompeu após um debate sobre qual seria a língua de instrução em Física e Matemática no Technikum (posteriormente chamado de Technion, a primeira instituição técnica de estudos superiores instalada em 1913 em Haifa pelo Ezra). Ezra era uma instituição filantrópica Judaico-Alemã que promovia e incentivava instituições educacionais em Eretz Israel. A decisão do Ezra de adotar o alemão como língua de instrução encontrou muitos opositores entre os estudantes e professores em todo o país. A guerra terminou com a vitória do hebraico. Em 22 de fevereiro de 1914, Ezra anunciou que a língua de instrução seria o hebraico e que todos os professores e magistrados que não possuíssem ainda o domínio da língua deveriam adquiri-la em quatro anos (SHAVIT, 2010, p. 1).

Essa vitória teve consequências muito além da questão propriamente técnica da língua: ela foi entendida como uma vitória simbólica do renascimento nacional judaico e anunciou o renascimento da língua hebraica como língua nacional da emergente comunidade de judeus na Palestina.

O grupo de jovens que aderiu prontamente à ideia de falar hebraico em todas as situações da vida moderna era composto de jovens intelectuais vindos do Leste Europeu

\footnotetext{
${ }^{30}$ Em hebraico significa "estudo". A obra mais importante da Torah Oral (vide nota abaixo), editada sob a forma de um longo comentário em aramaico sobre seções da Mishná. O Talmud também é conhecido pelo seu nome aramaico Guemara, que veio a ser amplamente usado para evitar críticas dos censores cristãos do Talmud, que o apontavam como uma insensata e revoltante obra anticristã. O Talmud foi redigido numa versão palestina (Ierushalmi, literalmente "de Jerusalém”) em 400 D. C., e uma versão babilônica mais autorizada (Bavli), cerca de 100 anos depois.

${ }^{31}$ Midrash em hebraico significa "busca”, "procura”. Método homilético de interpretação bíblica no qual o texto é explicado diferentemente de seu significado literal (pshat, em hebraico). Midrash também é o nome dado a várias coleções de tais comentários bíblicos, copilados da Torah Oral. O Midrash foi usado para conciliar contradições na escrita, para expressar ideias teológicas de forma imaginosa e para trazer uma mensagem contemporânea do texto bíblico às pessoas do povo.
} 
em consequência da onda de pogroms que havia assolado a Rússia e que desejavam construir uma vida nova tão diferente quanto possível da que haviam conhecido na Europa previamente. Estes colonos se estabeleceram em colônias agrícolas e posteriormente em Tel Aviv, que viria a ser a primeira cidade exclusivamente hebraica.

A fim de garantir e promover a modernização da língua foram fundadas sucessivas associações e, em 1890, finalmente, se criou o Vaad Halashon - Conselho da Língua Hebraica - presidido por Ben Yehuda até o seu falecimento, em 1922. Em 1948, com a criação do Estado de Israel, o Conselho converteu-se na Academia da Língua Hebraica.

Cabe lembrar que o processo de revitalização da língua hebraica, sua transformação efetiva em língua de comunicação e de uso diário, foi realizado por intelectuais e escritores de uma ampla e rica cultura judaica. Eles próprios se consideravam "revitalizadores" da língua hebraica, até então utilizada como "língua sagrada". A tarefa de "renascimento" foi empreendida por esses intelectuais de forma cuidadosa e sob uma profunda reflexão ${ }^{32}$. A este propósito parece-nos interessante reproduzir a carta de Guershom Sholem a Frantz Rosenzweig a respeito de sua preocupação com a secularização da língua hebraica.

Uma carta inédita de Gershom Sholem a Franz Rosenzweig a respeito de nossa língua ${ }^{33}$. Uma confissão, para Franz Rosenzweig, em 26.12.1926.

Esse país parece um vulcão onde a linguagem encontra-se em ebulição. Fala-se de tudo que poderia nos levar ao fracasso, e mais que nunca se fala dos Árabes. Mas existe outro perigo ainda maior que a nação árabe, e que é uma consequência necessária do sionismo: o que dizer da atualização da língua hebraica. Será que essa língua sagrada, que nutre nossos filhos não é como um abismo que não deixará de se abrir um dia Certamente, as pessoas aqui não tem noção do que estão fazendo. Elas acreditam ter secularizado (subtraído o conteúdo sagrado da língua hebraica, ter-lhe tirado o viés apocalíptico. Mas com certeza isto não é verdade. A secularização da língua é apenas um modo de falar, uma simples expressão. Impossível esvaziar a carga das palavras impregnadas de sentido, a não ser sacrificando-se a própria língua. $\mathrm{O}$ esperanto fantasmagórico que se fala em nossas ruas define exatamente o espaço linguístico inexpressivo, que somente a secularização da língua tornou possível. No entanto, se nós transmitíssemos aos nossos filhos a língua tal qual ela nos foi transmitida, se nós, geração de transição, ressuscitássemos para eles a linguagem dos velhos livros, para que ela pudesse novamente revelar-lhes seu sentido, não correríamos o risco de ver um dia o poder religioso de essa linguagem revoltar-se violentamente contra aqueles que a falam E, no dia em que essa explosão se der, qual será a geração que sofrerá as consequências. Quanto a nós, vivemos, no que diz respeito a maioria de nós, como cegos andando sobre um abismo. Mas, quando recuperarmos a visão, nós ou nossos descendentes, será que não cairemos no fundo desse abismo? E ninguém será capaz de saber se o sacrifício dos que foram

\footnotetext{
${ }^{32}$ Ben Yehuda editou seu dicionário inspirado no reconhecimento da continuidade linguística e histórica do idioma desde os tempos bíblicos até os dias modernos. Como exemplo, cito o termo bíblico: צלם (tzelem - imagem), raiz hebraica que serviu para criar - לצלם (o verbo fotografar) ou מצלמה (o substantivo máquina fotográfica).

${ }^{33}$ Carta traduzida do alemão ao frances por Stephane Mosès in "Les Yeux de la Langue" de Jacques Derrida.França, Editora Hermes, 2005. A tradução em português é minha.
} 
aniquilados nessa queda terá sido suficiente para preenche-lo. Os iniciantes do movimento de renascimento do hebraico tinham uma fé cega, quase que fanática no poder milagroso dessa língua. Essa foi a sorte deles, uma vez que se eles fossem dotados de clarividência, jamais teriam tido a coragem demoníaca de ressuscitar uma língua destinada a tornar-se um esperanto. São esses mesmos que continuam ainda hoje a avançar, como que enfeitiçados, sobre um abismo do qual nenhum som é ouvido e, que transmitem a nossa juventude os sons e as siglas de outrora. Quanto a nós, o medo nos toma de assalto, quando em um discurso somos subitamente tocados por um termo religioso, empregado sem discernimento, por um orador levado talvez por uma intenção de consolo. Essa língua está cheia de catástrofes a serem produzidas, ela não pode permanecer no ponto em que se encontra hoje, na verdade são os nossos filhos, eles que não conhecem mais outra língua, eles é que deverão pagar o preço desse reencontro que nós lhes preparamos, sem lhes termos colocado a questão, sem termos questionado a nós mesmos. Um dia a própria língua se voltará contra os que a falam. Nós já conhecemos tais momentos em que nos estigmatizam, que não poderemos jamais esquecer e que nos revelam toda a monstruosidade de nossa empreitada. Será que nesse dia teremos uma juventude capaz de fazer em face de revolta de uma língua sagrada. A linguagem é nome, substantivo. E é no substantivo que se esconde o poder da linguagem. É nele que está lacrado o abismo que ele contém. Pelo fato de ter invocado diariamente os substantivos de outrora, não depende mais de nós afastarmos o poder que eles encerram. Uma vez despertados, eles se revelarão, se manifestarão claramente, pois nós os invocamos com uma terrível violência. E verdade que a língua que nós falamos é rudimentar, quase fantasmagórica. Os substantivos, nossas frases, escritores e jornalistas jogam com eles, fingindo crer ou fingindo fazer D'Us acreditar que nada disso tem importância. E, no entanto, nessa língua aviltada e fantasmagórica, a força do sagrado parece sempre estar falando conosco. Uma vez que as palavras têm vida própria. Se não tivessem, coitados de nossos filhos, pois que estariam entregues a um futuro vazio. Dentre as palavras hebraicas, todas que não constituem neologismos, todas que foram emprestadas da nossa boa velha língua, são carregadas de sentido a ponto de explodirem. Uma geração como a nossa que toma a si a responsabilidade da parte mais fértil da nossa tradição, ou seja, sua língua, não poderá, mesmo que o queira fervorosamente, viver sem tradição. Quando chegar a hora em que o poder escondido contido no fundo da língua voltar a se manifestar, onde o dito da língua, seu conteúdo, recuperar sua forma, nosso povo se verá de novo confrontado com essa tradição sagrada, sinal mesmo da escolha a ser feita. Então, nesse momento, será necessário submeterem-se, ou desaparecerem. Pois no âmago dessa língua, em que a todo instante não se para de evocar D'us de todas as maneiras, fazendo-o voltar de certo modo à realidade de nossa vida, o próprio D’us, por sua vez não ficará silencioso. No entanto, essa inelutável revolução da língua, em que a Voz se fará ouvir novamente é o único assunto do qual não se fala nunca nesse país. Isto porque aqueles que se empenharam em ressuscitar a língua hebraica não acreditavam na realidade do julgamento ao qual nos submeteram a todos. Queira D'us que a leviandade com que fomos arrastados por esse caminho apocalíptico não nos leve a nosso fim, à nossa perda. (SHOLEM, Guershom, 26. XII. 1926 apud DERRIDA, 2005).

Esta concepção, entretanto, modificou-se radicalmente com a vinda da geração dos "sabras" (filhos dos imigrantes nascidos em Israel), cuja língua materna era o hebraico, desprovido totalmente de qualquer conotação de língua religiosa-secularizada.

Esta primeira geração, impregnada de sua privilegiada posição de judeus não diaspóricos - nascidos em Israel sob a égide da ideologia sionista do "novo judeu" cunhou um estilo peculiar de conversação de gramática e de vocabulário. O hebraico dessa geração caracterizou-se por um estilo de fala informal, ríspido e econômico, avesso às formas de tratamento consideradas civilizadas e educadas e à arte da retórica (דוגרי). Seu objetivo maior na fala era ressaltar o aspecto coletivo nesse horizonte específico e a eficácia na comunicação intergrupal.

A mistura de códigos linguísticos (o renascimento proposto por Ben Yehuda e pelos demais intelectuais pertencentes à sua geração em oposição às gerações de 
sabras), as ondas sucessivas de imigrantes que chegam a Israel e o processo da globalização (com a predominância da língua inglesa) hegemônica no mundo atual vêm produzindo em Israel uma tendência a constantes inovações na Língua Hebraica, que é resultado de múltiplos estratos de diferentes camadas de conversação e de diferentes grupos sociais ${ }^{34}$. Esses fenômenos refletem a complexidade que envolve as transformações ocorridas com a Língua Hebraica, em Israel e na Diáspora.

\subsection{Entre Israel e a Diáspora}

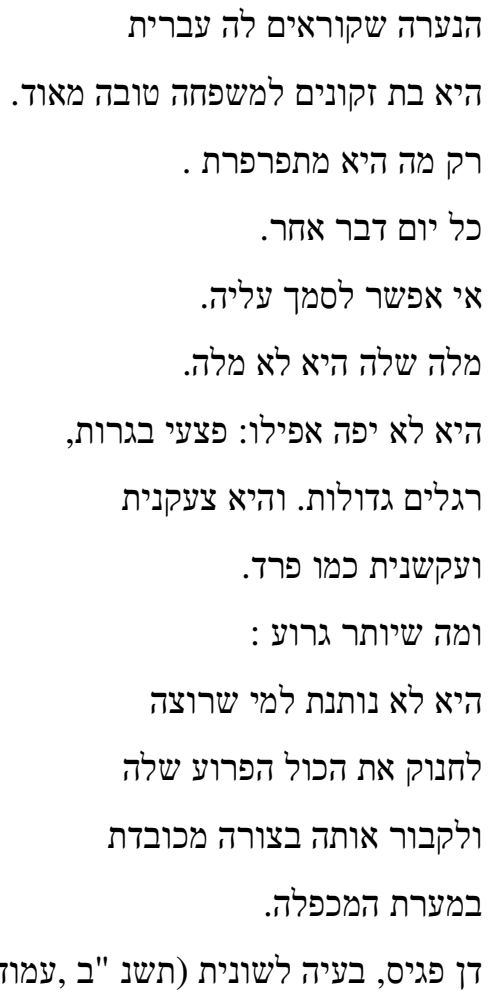

The maiden we call Hebrew

is the youngest born in a very good family.

Her problem, though: she messes around.

Every day it's another story.

You can't rely on her,

her word carries no weight.

She's not very pretty:

\footnotetext{
${ }^{34}$ Referimo-nos ao conceito de Multiglossia em oposição ao conceito clássico de diglossia, cunhado por Ferguson (cf. 1959, 'Diglossia', World 15, p 325-340).
} 
she's got acne, large feet, is loud and stubborn as a mule.

And what's worse:

she won't give in to those

Who want to stifle her unruly voice

and bury her, respectfully, in the ancestral tomb.

(PAGIS, Dan. A Linguistic Problem. Translation of Ms. Tsipi Keller)

Passadas algumas décadas após o restabelecimento do Estado Judeu em Israel, o hebraico espalhou-se pelo mundo judaico como a principal língua e, sobretudo, tornouse a principal língua judaica a ser estudada nos programas educacionais judaicos, incluindo os Estudos Judaicos nas universidades e escolas. Desde então a língua hebraica passou a gozar de um status peculiar e exclusivo em todas as coletividades judaicas.

De fato o hebraico, que sempre prevaleceu na diáspora como uma língua sagrada ou literária, sofreu transformações semânticas, morfológicas e sintáticas em consequência da nova realidade israelense. Em Israel, o hebraico-israelense foi amplamente reconhecido pela sociedade como língua de prestígio, tornando-se sinônimo do "novo judeu", cujo falar expressava a condição dos sabras ${ }^{35}$, geração nascida em Israel, em oposição aos judeus da diáspora. Os sabras, na condição de judeus nascidos em Israel, sentiram-se à vontade em usar a língua hebraica à sua maneira, uma vez que para eles o hebraico era a língua nacional - língua materna desprovida do carisma de língua "sagrada-secularizada".

O holocausto, como se sabe, dizimou a maioria dos judeus falantes do Ídiche, que perdurou durante um longo período como o centro da autêntica cultura judaica. Após 1945, encabeçados pelo judaísmo americano, os judeus passam a experimentar um novo estilo de vida. Adquiriram nos países modernos democráticos plenos direitos como cidadãos, apesar do antissemitismo velado, sendo-lhes concedida a manutenção e preservação de sua singularidade cultural e religiosa.

Nesse novo contexto abriu-se para esses judeus a possibilidade - e não são poucos os que quiseram - de assimilar-se cultural e socialmente e, sobretudo, imprimir uma nova identidade coletiva. Dado o afastamento ocorrido com o enfraquecimento das raízes culturais judaicas entre os imigrantes e o aumento dos casamentos interétnicos

\footnotetext{
${ }^{35}$ Sabra - do hebraico, fruta espinhosa por fora e tenra por dentro e nome designado para aqueles que
} nascerem no Estado de Israel. 
(mistos), o número de judeus diminuiu consideravelmente fora de Israel, e particularmente em alguns países.

Nessa realidade em que judeus e não judeus convivem lado a lado, as línguas judaicas que perduraram durante centenas de anos como línguas de criatividade cultural e como instrumentos de comunicação diminuíram e se desgastaram ${ }^{36}$.

O inglês tornou-se a língua franca no mundo atual e imprimiu de forma marcante sua influência tanto em Israel como no mundo judaico. Somados aos judeus dos Estados Unidos, Inglaterra, Irlanda, Austrália e Nova Zelândia, que representam 50\% do total dos judeus de todo o mundo, é notável o número de intelectuais judeus de outros países e, sobretudo, cidadãos israelenses provenientes de todas as camadas sociais que falam e estudam inglês com fins acadêmicos e profissionais desde o jardim de infância até a Universidade. De fato, em Israel a língua inglesa adquiriu, embora não oficialmente, um status extremamente poderoso como segunda língua, e vem influenciando de forma significante a língua hebraica.

Cabe lembrar, entretanto, que mesmo sendo o inglês a língua franca e hegemônica no mundo, esta não é reconhecida como uma língua judaica. Este lugar paradoxalmente é reservado à língua hebraica.

Para Ben Rafael (2007, p. 19), o status adquirido pela língua hebraica no mundo judaico deve ser atribuído, sobretudo, à relação paradoxal que se estabeleceu entre Israel e a atual diáspora. $\mathrm{O}$ conceito, segundo este autor, que melhor explica esta relação é o da "Diáspora Transnacional"37, que atualmente se aplica a vários outros grupos igualmente espalhados pelo mundo. Nesse contexto, a língua hebraica passou a desempenhar uma função exclusiva, peculiar, entre o "povo judeu”.

Já há vários anos os judeus em Israel representam uma parte importante do judaísmo mundial. Atualmente, os judeus de Israel, com seus 5,5 milhões, representam numericamente a maior concentração de judeus do mundo, superior aos 5,2 milhões que moram nos Estados Unidos ${ }^{38}$. Sob este aspecto, a relação que se mantinha com Israel e com os judeus de Israel não depende mais do sionismo, mas da própria existência do

\footnotetext{
${ }^{36}$ Fishman, J. A. (Ed). (1985). Readings in the Sociology of Jewish Languages, Amsterdam: Brill.

${ }^{37}$ Referimo-nos ao conceito sociológico cunhado como "Diáspora - Transnacional" em que um grupo de origem determinada, apesar de encontrar-se espalhado por várias regiões no mundo, preserva sua origem coletiva de pátria histórica.

${ }^{38}$ Segundo o recenseamento do ano de 2003 realizado nos Estados Unidos e segundo os dados de Sergio della Pergula (apud, Ben Rafael, 2007, p. 20).
} 
Estado de Israel. Criou-se uma solidariedade coletiva entre a diáspora e Israel, que pode ser definida como כלל ישראל a totalidade do "povo judeu".

Essa relação paradoxal nos ilustra a definição do Estado de Israel como um "Estado Judeu" e como um Estado para o "Povo Judeu", ou seja, a concepção que prevalece para muitos na diáspora de que o Estado de Israel é parte integrante do povo judeu (Ben Rafael, 2007, p. 21).

É precisamente esta relação que torna a função da língua hebraica na atual realidade judaica na diáspora complexa e multifacetada. Por um lado, o permanente apoio oferecido pelos judeus da diáspora a Israel e suas instituições cria uma dependência com a diáspora. Por outro lado, Israel ocupa um lugar significativo na vida judaica da diáspora considerado central na abordagem, no interesse e na ligação da existência coletiva judaica na atualidade. Essencialmente, a natureza dessa relação poderia ser definida como um círculo em permanente estado de mudanças.

Israel se tornou atualmente um repositório de onde a diáspora absorve seu manancial de símbolos para representar o seu judaísmo como parte do mundo judaico. Pratos típicos israelenses, música e dança se tornaram símbolos judaicos em eventos comemorativos na diáspora. Da mesma forma, a literatura israelense, atualmente traduzida ao Francês, Inglês e demais línguas estrangeiras, vem ocupando um lugar de destaque no mundo judaico e, sobretudo, a língua hebraica vem adquirindo um status e reconhecimento como a principal língua judaica na atualidade.

Após ter sido ensinada na diáspora, quer seja como língua sagrada ou literária em instituições religiosas ou laicas sionistas e não sionistas, e após a criação do Estado de Israel, a língua hebraica passou a ser adotada em todas as instituições judaicas do mundo como a principal língua judaica e a ser ensinada segundo o padrão de língua hebraico-israelense dominante em Israel. Este também é o hebraico ensinado nas diversas universidades em torno do mundo nos departamentos de Estudos Judaicos e ainda é estudado e ensinado nas instituições do $\mathrm{Chabad}^{39}$, que adotou a língua hebraica como língua de comunicação por seus missionários, tanto em Israel como na diáspora. Cabe mencionar ainda o uso da língua hebraica nas orações das sinagogas, em cerimônias das comunidades referentes a datas ligadas ao calendário judaico ou eventos cívicos do Estado de Israel, bem como nos festivais de filmes israelenses.

\footnotetext{
39 Sigla para denominar a instituição ortodoxa hassídica espalhada em todo o mundo e que se tornou a potência oculta do judaísmo mundial na atualidade.
} 
Embora a língua hebraica israelense seja considerada a principal língua judaica na atualidade ${ }^{40}$, o conhecimento da língua hebraica no mundo judaico é fraco. Entre os que apresentam um conhecimento maior, geralmente encontramos rabinos, ativistas de instituições comunitárias, jovens que passaram por escolas judaicas, movimentos juvenis ou que frequentaram os diversos programas oferecidos pela Agencia Judaica, ou ainda pessoas que permaneceram certo tempo em Israel.

O segmento que vem contribuindo de forma significativa com a presença da língua hebraica na diáspora é, sobretudo, o da "diáspora israelense", sendo esta uma parte integrante do judaísmo mundial atualmente. Este grupo fala o hebraico como os demais israelenses, porém seus filhos não necessariamente dominam a língua. $\mathrm{O}$ grupo majoritário não israelense e não ortodoxo contenta-se com palavras e expressões hebraicas retiradas da cultura judaica e, quando necessário, expressa seu judaísmo em uma língua estrangeira.

De forma paradoxal, o segmento que tem melhor conhecimento da língua hebraica é justamente o dos charedim - judeus ultraortodoxos, que, em sua maioria, têm uma visão crítica do Estado de Israel. Este grupo argumenta em favor da preservação do Ídiche como língua de comunicação e em favor de adotar o inglês, francês ou russo como língua oficial para facilitar o relacionamento de Israel com o mundo não judaico.

Atualmente, porém, a língua sagrada estudada nesses segmentos religiosos aproxima-se cada vez mais da língua hebraica falada pelos que vivem em Israel, e tem sido usada de forma recorrente pelos grupos ortodoxos que, na condição de turistas que visitam Israel, estudam nas Yeshivot $^{41}$ de Jerusalém ou de Bnei Brak (BEN RAFAEL, 1994).

O projeto de hebraização, a criação de uma língua e cultura comum para os judeus que imigraram para Eretz Israel com o propósito de ali criar seu "lar nacional", foi visto como o emblema do empreendimento sionista. A língua hebraica ganhou um caráter eminente no renascimento nacional judaico, revestiu o sionismo de um impulso

\footnotetext{
${ }^{40}$ Este fato não exclui as demais línguas judaicas como, por exemplo, o Ídiche que permanece em uso em comunidades ortodoxas como língua de comunicação diária. Ou mesmo, o Ladino, preservado em círculos judaicos em diferentes partes do mundo. Entretanto, o mapa linguístico do mundo judaico mostra a superioridade determinante do hebraico-israelense como língua judaica.

${ }^{41}$ No plural (yeshivot), do hebraico "ato de sentar". Colégio Talmúdico para estudantes solteiros desde a puberdade até aproximadamente os 20 anos. Os casados após estudarem na Yeshiva podem seguir seus estudos religiosos num "Kolel". As Yeshivot se originaram das academias da Palestina e da Babilônia, nos primeiros séculos da era cristã, e as mais contemporâneas têm como modelo as Yeshivot lituanas do século XIX e início do XX.
} 
político sem precedentes e conclamou o renascimento nacional judaico na terra de Israel.

De fato, somente uma cultura "hebraica" comum poderia transformar vários grupos falantes de línguas diferentes, de diferentes sistemas simbólicos, e diferentes códigos culturais em uma sociedade nacional com um sistema de valores compartilhado.

Com a restauração do Estado de Israel a língua hebraica se tornou no mundo judaico a principal língua judaica. Dadas as relações paradoxais que se estabeleceram com a diáspora na atual realidade social histórica, a língua hebraica passou a gozar de um status peculiar e exclusivo em todas as coletividades judaicas e tornou-se um vetor heterogêneo de identificação linguístico-cultural e de identidade judaica.

\section{CONTEXTO HISTÓRICO DA EDUCAÇÃO JUDAICA NO BRASIL}

A comunidade judaica no Brasil e, em especial, a comunidade de São Paulo, registrou sua presença durante esses cinco séculos de existência através de efetivas contribuições no plano social, econômico, industrial, intelectual e artístico. Historiadores como Cecil Roth (1962) Falbel (1984) e Nachbin, Jacob (1929) comprovam em seus livros a presença de judeus assumidos de origem portuguesa e de cristãos-novos desde a época do descobrimento do Brasil e entendem que as bases da atual comunidade judaica no Brasil foram lançadas, efetivamente, depois de 1822, quando o Brasil se tornou independente de Portugal e a imigração fez-se sem maiores restrições. (FALBEL, 1984, p.67).

O grande surto imigratório, no entanto, proveniente da Europa Oriental para a Ocidental, para a América do Norte e para os países latino-americanos, começaria a partir dos anos 1880 e 1890. Esse processo imigratório, considerado o maior no plano universal da história dos judeus, provocou o deslocamento de milhões de judeus $\operatorname{ashkenazitas}^{42}$ que viviam na chamada Zona de residência do Império Czarista

${ }^{42}$ Os ashkenazitas são originalmente judeus de ascendência alemã. O nome bíblico Ashkenaz (Gênesis, 10:3; Cr. 1:6; Jer. 51:27) era tido na Idade Média como referente à Alemanha. Como a maioria dos judeus de países cristãos da Europa Ocidental, Central e Oriental da Idade Média aos tempos modernos, eram culturalmente e demograficamente descendentes dos judeus franco-alemães, o termo ashkenazita veio a 
(caracterizada por uma grande concentração populacional sem meios favoráveis de subsistência). Esse período coincide com a intensificação dos pogroms contra os judeus: em Balta (1882), Starodub, Odessa e Kiev (1891), Bialystok (1904), Minsk e Lodz (1905), entre outras localidades, somando um total de 284 cidades ucranianas, polonesas e russas num período de quatro anos (cf. Falbel, 1984, p. 37; Gutfreind, 2004, p. 28).

Nesse período ocorre a criação da Jewish Colonization Association ${ }^{43}$ (ICA ou JCA, 1891) pelo Barão Maurício de Hirsch e outros associados, qual seja, a fixação de colônias agrícolas no Novo Mundo como o melhor caminho para a salvação daquela massa humana, que vivia na mais extrema miséria. Cabe lembrar, no entanto, que já nas últimas duas décadas do século XIX havia uma imigração da Europa Oriental proveniente principalmente da Rússia de forma isolada e individual. Essas famílias se instalaram principalmente em São Paulo, Rio de Janeiro, Franca-SP, Curitiba e Porto Alegre.

Acontecimentos internacionais, como a eclosão da I e II Guerra Mundial, também contribuíram para o deslocamento de imigrantes para os Estados Unidos, Canadá e América do Sul. Entre os anos de 1904 e 1918, a vida judaica na Rússia foi totalmente abalada. O exército alemão destruiu aldeias, vilarejos e guetos inteiros. Centenas de milhares de judeus foram deslocados, desarraigados de sua permanência centenária, secular, tradicional dos schtetels (aldeias) e de sua língua, o Ídiche. (cf. Falbel, 1998, p. 15).

É importante aqui mencionar que o Ídiche tem sido historicamente a língua dos ashkenazitas e seus descendentes na diáspora. Max Weinreich, estudioso do Ídiche, a define como uma língua híbrida que contém elementos do Germânico, Eslavo, Semítico e outras línguas ${ }^{44}$ : "uma fusão de línguas" (WEINREICH, 1980, p. 34). A maioria dos linguistas concorda que, em sua essência, o Ídiche é uma língua germânica ocidental.

ser aplicado a todos eles. O complexo cultural ashkenazita envolve o uso de diferentes dialetos da língua Iídiche como língua franca judaica, distintos rituais, costumes, liturgia, arquitetura sinagogal, método de estudo e pronúncia do hebraico, os quais diferenciam os ashkenazitas de seus correligionários sefaraditas e das comunidades judaicas orientais, mizrahim.

${ }^{43}$ Referimo-nos à associação de caráter filantrópico criada em 24 de agosto de 1891, em Londres, doada quase que exclusivamente pelo Barão Maurice de Hirsch com o objetivo de assentar judeus em colônias agrícolas e ajudá-los em sua emancipação econômica em diversos territórios da América do Norte e do Sul, bem como em outros lugares.

${ }^{44}$ Como exemplo da mistura de seus componentes, Weinreich, M. (1980) traz o seguinte exemplo: Der zeyde hot gebentsht khanike likht - $\mathrm{O}$ vovô acendeu as velas de Chanuka. A gramática básica é alemã, assim como atestam as palavras "der" e "hot", o passado simples marcado pelo "ge - $e-t$ ", e a palavra 
A palavra Ídiche, em Ídiche, significa simplesmente judeu. No passado, várias designações foram usadas para enfatizar a estreita relação entre o Alemão e o Ídiche ${ }^{45}$. A língua ídiche é também referida pelo seu termo derrogatório original "jargão", jargon ou, às vezes, em seu sentido mais sentimental afetivo de mame-loshn, "língua materna", em contraste com a efetivamente chamada "língua sagrada", Loshn Koidesh (termo do hebraico - aramaico).

O Ídiche, ao que tudo indica, originou-se nas áreas fronteiras franco-germânicas por volta do século X e XI (GUINSBURG, 2004). Judeus vindos principalmente da Itália e de outros países românicos adotaram o idioma local, ou seja, o alto alemão, em sua passagem do período antigo para o médio. Conforme Guinsburg,

Misturando-se desde logo, com elementos do laaz ${ }^{46}$, correlativo judaico em francês e italiano arcaicos ${ }^{47}$, com a terminologia litúrgica, ritual, comercial e institucional do hebraico-aramaico, isto é, o chamado lashon-kodesh, em Ídiche, loschen koidesh ("língua sagrada"), com palavras hebraicoaramaicas $^{48}$ ligadas à atividade diária e eufemismos destinados a ocultar ao não judeu o significado dos termos, começaram a desenvolver juedischdeutsch, isto é, "judeu-alemão" (GUINSBURG, 2004, p. 145).

Em virtude dos constantes deslocamentos dos judeus devido às chacinas cometidas pelos Cruzados, o Ídiche reuniu contribuições de diferentes dialetos alemães que vieram acentuar as características de jargão específico da judengasse (rua dos judeus), do gueto (Velho-ídiche, 1250-1500). Em sua época arcaica (Proto-ídiche, 10001250), entretanto, o Ídiche não se diferenciou muito do médio alto-alemão. Era a linguagem do cotidiano e, sobretudo, das mulheres, que não aprendiam o hebraico.

likht. Zeyde é eslavo, khanike é semítico e bentsh é um componente do Romance. Sentenças como essas são comuns em Ídiche.

45 O juedisch - deustch, isto é, o "judeu - alemão", nome que se alterou para idische-taitsch "ÍdicheAlemão", sobreviveu ao Ídiche moderno com o verbo fartaytshn (que também significa interpretação em Ídiche).

${ }^{46}$ Laaz ou, como pretende Weinreich, "Loez”, língua estrangeira "não hebraica” ou língua de um povo estrangeiro. Designação que se estendeu às glosas e glossários em vernáculos, sobretudo, românicos escritos em caracteres hebraicos de que se serviam os comentadores judeus na Idade Média e que constituíram o início de adaptação do alfabeto hebraico ao Ídiche (vocalização, ditongos).

${ }^{47} \mathrm{O}$ francês e o italiano antigos desempenharam também papel relevante entre os constituintes do Ídiche. Seus vestígios persistem em palavras como aiker - alcove, aimer - armoire, bentschen - benés. E em nomes próprios como Schnoier - Senior, Bunem - Bonhomme, Schprintze - Esperanza.

${ }^{48}$.Hebraísmos como Din (“julgamento"); kasher, em ídiche, kosher ("ritualmente puro"); Iom - Tov, em ídiche, Iontev ("dia de festa"); Gan Eden, em ídiche, Gan-Eiden ("jardim do paraíso"); Torá, em ídiche, Toire ("Lei","Ensinamento"); bem como aramaísmos, isto é, os dois constituintes linguísticos semíticos do que é efetivamente chamada "língua sagrada" figuram certamente entre os primeiros componentes do Ídiche. Posteriormente, com o Hassidismo em particular, a participação dos hebraísmos e dos aramaísmos do discurso religioso aumentou consideravelmente no vocabulário ídiche. 
Com as perseguições sofridas no curso do Medievo, sucessivas ondas de judeus ashkenazitas emigraram em massa para o leste da Europa e também para outras áreas, levando o seu dialeto como uma comunicação intragrupal, usado de forma generalizada em todas as esferas de comunicação da vida coletiva (GUINSBURG, 2004).

Cabe ressaltar que a língua ídiche, até a segunda metade do século XIX, era vista como um "jargão" mesmo por aqueles que a empregavam não somente para a comunicação oral. Dada a sua flexibilidade e permeabilidade às influências locais, sem qualquer disciplina gramatical mais definida de "língua" deixada ao sabor da "fala", tendia a regionalizar-se com grande facilidade e, portanto, desenvolveu já no século XVIII, segundo Guinsburg, dois grupos dialetais no quadro da Europa Oriental: "o do Norte, centrado na Lituânia, e o do Sul, que abrangia a Polônia com forte peculiaridade, a Ucrânia e a Romênia”. (GUINSBURG, 2004, p. 145). Esses dialetos correspondem a fronteiras históricas e não devem ser confundidos com o atual mapa político geográfico dessas regiões. Diferentemente de Mendelsson e seus seguidores, na Europa Central, que julgavam, para seus ideais de modernização, eliminar "o jargão" como barbarismo linguístico e cultivar o hebraico e o idioma oficial do país em que os judeus habitavam, foi no Leste europeu com o movimento da ilustração judaica na Rússia que se começou a escrever em "jargão". A princípio por razões propagandistas, e mais tarde, por razões ideológico-políticas, uma vez que o Ídiche se tornara o veículo de entendimento coletivo entre os judeus. A partir daí desenvolveu-se uma vasta produção literária nos estados da Europa Oriental por socialistas populistas, "nacionalistas da Galut" (diáspora) que viram no Ídiche uma manifestação própria dos judeus - uma espécie de segunda língua nacional do povo judeu como foi manifestada na Conferência de Tchernovitz em 1908.

Esse vigor no idichismo, a vasta produção literária somada ao incremento dos meios de comunicação, acelerou o processo de normatização e consolidação linguística, servindo-se dos recursos da ciência moderna. Este desenvolvimento prosseguiu com vigor até a Segunda Guerra Mundial, quando foram erradicadas as raízes mais profundas do Ídiche com a barbárie institucionalizada pelo Estado alemão: o holocausto.

Mesmo antes da propaganda nazista, o espírito antissemita e o sentimento de repulsa aos judeus já existiam na Europa Oriental e Ocidental: na França, Áustria, Polônia e Rússia. Boatos por crime ritual espalharam-se, aterrorizando as comunidades judaicas. Eram promovidas perseguições aos judeus conhecidas como "pogroms". Na Alemanha, o "antissemitismo moderno", sustentado pelo conceito de superioridade da 
raça, culminou com o extermínio físico proposto por Hitler: a solução final, eliminando seis milhões de judeus até o final da segunda guerra mundial.

No Brasil, entre os anos de 1914 e 1933 presenciamos a formação das instituições comunitárias, pois com o término da guerra os imigrantes sentiram a necessidade de criar raízes em terras brasileiras. Sinagogas, bibliotecas e instituições de amparo ao imigrante surgiram no Rio de Janeiro, em São Paulo e Porto Alegre ${ }^{49}$. É publicado em Porto Alegre, por Joseph Halevi o primeiro jornal judaico no Brasil, em 1915, em língua ídiche. Chamava-se "Das Menscheit”, "A Humanidade" (que, infelizmente, se desfez rapidamente por razões ideológicas).

Em nossa retrospectiva histórica da Educação judaica no Brasil, visando ao nosso objeto de estudo - a atual realidade de ensino-aprendizagem da língua hebraica -, utilizaremos como fonte de conhecimento a imprensa judaica (cf. Falbel, 1998), que tem sido um fator importante para o conhecimento da história mais recente da imigração judaica do século XX.

A imprensa judaica foi escrita em sua maioria em Ídiche, uma vez que as primeiras levas imigratórias da Europa Oriental fizeram do Ídiche sua língua de expressão cultural. (FALBEL, 1988:14) Entretanto, a chamada imigração sefaradita de fala espanhola ou de fala de dialetos ladinos ou ibéricos, da África do Norte, da Turquia, da Grécia, que constitui outro segmento da imigração, teve a sua imprensa escrita em português. A partir de 1916 foi publicado no Rio de Janeiro em português o primeiro periódico judaico pelo professor David José Perez ${ }^{50}$, A Coluna, com o subtítulo Haamud (do hebraico: a coluna). E em Belém do Pará, em 1918, o major Eliezer Levi ${ }^{51}$ publicou o jornal Kol Israel, A voz de Israel.

49 Referimo-nos à formação do Comitê Brasileiro de Socorro aos Israelitas Vítimas da Guerra (correspondendo ao americano Jewish Relief Committee) com representantes da sociedade carioca. E, em São Paulo, sob a presidência de Bernardo Nebel constituiu-se um Comitê representado pela Comunidade Israelita, Sociedade Ezra, Talmud Torah, e pelo Clube Philo Dramático Musical. (cf. Falbel, 1984, p. 112).

${ }^{50}$ David José Perez (1883-1970) - Personalidade multifacetada e rica permeada por uma múltipla atuação como jornalista, advogado, escritor, professor ativista comunitário e intelectual. Foi criador do primeiro periódico judaico no Brasil em língua portuguesa, o mensário A Columna estendendo sua atividade na divulgação da comunidade judaica brasileira, até então, pouco conhecida na sociedade brasileira. Teve um papel central na criação da primeira escola judaica do Rio de Janeiro denominada Maguen David e na estruturação do movimento sionista no Brasil juntamente com Mauricio Klabin e Jacob Shnaider.

${ }^{51}$ Major Eliezer Levy, sionista convicto, havia fundado em 1918 a organização sionista Ahavat Zion, em Belém do Pará, e em 8 de dezembro do mesmo ano deu início à publicação do periódico com o título de Kol Israel. Eliezer Levy teve no ano de 1919 um papel de destaque na educação judaica ao criar o Externato Misto Dr. Weizmann. 
Cabe, entretanto lembrar, que com a expulsão dos judeus da Espanha (1492), produziu-se a conhecida Diáspora Sefaradita, que impulsionou milhares de judeus e cristãos novos a buscar refúgio em terras onde pudessem se estabelecer e praticar livremente sua religião. Perseguidos pela Inquisição e pelas leis racistas instituídas pelos Estatutos de "Pureza de Sangue" vigentes em todos os domínios ibéricos desde o século XV, os sefaraditas se espalharam pelo Norte da África, Império Otomano, parte da América do Sul, Brasil, Argentina, Itália, Holanda, Grécia e Turquia. Levaram consigo uma cultura judaica altamente desenvolvida, bem como seus costumes, liturgia, tradições musicais e sua língua latina com novo rumo evolutivo.

Dispersos pelos vários domínios do Império, os judeus viram-se submetidos a uma única autoridade e, no longo período em que assim permaneceram, os dirigentes otomanos valeram-se dos empréstimos e conhecimentos dos sefaraditas, não só para a expansão e comércio regional e internacional como para incremento das finanças, na diplomacia, nos negócios bancários, na corretagem e na ourivesaria. Nos 400 anos do Império, os judeus ocuparam cargos político-administrativos otomanos, colaborando inclusive com a estratégia de colonização dos vastos impérios.

Os otomanos fizeram prevalecer em seu Império um sistema administrativo conveniente às diferenças étnicas e religiosas. Cada grupo religioso poderia se organizar em comunidades próprias e autônomas - Millet $^{52}$ - dirigido por um chefe religioso, responsável pela administração e cumprimento das leis. Este sistema beneficiou às minorias, em especial à judaica, e contribuiu para a preservação de sua identidade cultural religiosa. Um decreto imperial de 1836 criou o cargo de Chacham Rashi, rabino-mor, equiparando-o aos chefes eclesiásticos das Igrejas gregas e armênias. O rabino-mor tinha autoridade sobre outros centros judaicos do Império, inclusive sobre as cidades da antiga Palestina. A autonomia das Millet revelou-se bastante conveniente não só ao poder otomano, mas às comunidades religiosas, pois puderam preservar suas tradições, costumes e as línguas maternas desde que cumprissem as obrigações legais e recolhessem os impostos devidos ao Estado.

Segundo Penny (1992), o Ladino, língua atribuída aos judeus originários da Espanha, floresceu no Império Otomano, após a expulsão dos judeus da Espanha. Os

\footnotetext{
${ }^{52}$ Refere-se ao sistema de organização administrativa adotado pelos Sultões. Cada grupo religioso podia se organizar em comunidades próprias e autônomas - dirigido por um chefe religioso desde que cumprissem as obrigações legais e recolhessem os impostos devidos ao Estado. Foi a partir dessa organização administrativa que o Estado Otomano estruturou-se como sociedade multicultural.
} 
sefaraditas acrescentaram ao romance ibérico da Espanha Cristã Medieval palavras portuguesas, árabes, turcas e hebraicas, além de neologismos, usando para a escrita o alfabeto hebraico. Conservaram, todavia, estreita identidade com o espanhol e o português.

O programa de Colonização da ICA no Rio Grande do Sul levou dezenas de famílias a se estabelecerem nas colônias agrícolas de Philippson e Quatro Irmãos, onde mais tarde desenvolveram uma sólida vida comunitária no Estado. Dessa forma, coube a JCA dar início, em 1904, à criação da primeira escola judaica no Brasil, como resultado da preocupação dos colonos de transmitirem aos seus filhos o conhecimento necessário da língua de seus pais, e também da tradição de seus antepassados.

No livro de memórias de Frida Alexander (1967) encontramos depoimentos sobre as aulas de Ídiche e Hebraico que ali eram ministradas. Segundo esta autora, inicialmente as aulas eram dadas em um anexo do shill (sinagoga) pelo Rebe Abrão Waissman, no estilo do Beit Midrash europeu. Mais tarde, no entanto, com a vinda do eminente pedagogo Léon Back e do professor Israel Becker, criou-se um programa mais completo na escola, reconhecida e supervisionada pelos órgãos educacionais do Estado. (cf. Alexander, Frida, p.31-37).

O primeiro professor a ser trazido de Paris a Philippson foi o Dr. Léon Back ${ }^{53}$, em 5 de junho de 1908. A partir de 1929, segundo depoimentos do professor Jacob Levin, professor nos núcleos colonizadores de Quatro Irmãos, e que, mais tarde, tornouse um dos educadores da Escola Talmud Thorá de São Paulo, em 1935 formaram-se escolas nos núcleos de Barão Hirsch, Baronesa Clara e Pampa. A partir de 1929, o professor Levin, além de lecionar matérias judaicas (Ídiche, Hebraico, História Judaica, Tanach), ficou com a função de supervisor das escolas nessas colônias (cf. Falbel, 1984, p. 122). Entendemos que essas escolas certamente serviram de incubadoras para a formação de professores de outras escolas em outras cidades do Brasil.

As escolas judaicas tiveram, desde sua criação pela JCA, total apoio, tanto financeiro como espiritual, do seu representante no Brasil, o Dr. Isaias Raffalovich ${ }^{54}$,

${ }^{53}$ Léon Back atuou como professor e subdiretor da École Horticole et Profissionelle du Plessis - Piquet nos arredores de Paris. Léon Back instalou ali uma escola mista (Cf. Enciclopédia Rio Grandense, volume $5)$.

54 Rafallovich nasceu em 1870 em Bogopol, uma pequena cidade da Podolia. Em 1882 seus pais emigraram a Eretz Israel devido à onda de pogroms que se sucederam um ano antes do assassinato do Czar Alexandre II e que provocou uma emigração em massa da Rússia Czarista em direção ao Ocidente. Em Eretz Israel, em Jerusalém, juntamente com seu irmão estudou em Yeshivot (escolas talmúdicas) sob a orientação de professores de fama reconhecida por sua erudição rabínica. Envolvido com o projeto de 
rabino-mor do Rio de Janeiro que chegou a essa cidade em 1923. Personalidade de sólida e erudita formação judaica, ele exerceu um papel fundamental na formação das instituições de ajuda ao imigrante, bem como na formação da rede escolar judaica no Brasil. (cf. Falbel, 2008: 335).

O Rabino Rafallovich foi convidado, em virtude do excelente trabalho e de sua dedicação aos imigrantes na Europa, a implementar o projeto de colonização agrícola, já existente no Rio Grande do Sul desde 1904. Inicialmente, os membros da Associação de Ajuda e Amparo ao Imigrante (Relief) no Rio de Janeiro mostraram-se bastante relutantes em aceitar sua cooperação, uma vez que os funcionários da ICA eram vistos como assimilacionistas, e no Brasil a administração nas colônias locais era alvo de severas críticas. (cf. Falbel, 2008: 336).

Para Rafallovich duas questões faziam-se importantes em seu projeto comunitário: a primeira consistia em criar cooperativas de crédito para o imigrante e a segunda era viabilizar a criação de escolas locais. Seu projeto almejava, de fato, integrar o imigrante à sociedade local através de instituições sociais e oferecer aos seus filhos escolas nas quais se pudesse dar continuidade às suas tradições e à herança cultural de seus antepassados, fato que demandava investimentos e grandes esforços, pois a situação dos imigrantes que aqui aportavam era precária. Em seus relatos, no livro Tziunim vê Tamrurim, ele aborda aspectos relativos à formação e à orientação dada às escolas da época. Em particular, traz depoimentos concernentes à introdução do estudo do hebraico, ao lado da língua ídiche, sendo por isso muito atacado pelos idichistas. Em suas conferências ele expressava seu receio à assimilação e via a educação como uma forma de se contrapor a esse processo Sua atividade itinerante pelo vasto território brasileiro acabaria por ter um resultado surpreendente na criação de novas escolas (FALBEL, 2008, p. 339).

Com o impulso que Rafallovich deu à Sociedade de Ajuda e Amparo ao Imigrante no Rio de Janeiro desde que chegara e com a criação do HICEM $^{55}$ (fusão do

Colonização Judaica durante o governo turco, uniu-se ao movimento Chovevei Tsion participando na divulgação dos resultados dessa colonização no terceiro Congresso Sionista na Basileia, realizado em 1899. Após concluir sua smichut (título de autoridade rabínica) em Manchester, na Inglaterra, passou a atuar em instituições para dar assistência aos imigrantes judeus que passavam pela Europa a caminho da América, especialmente a partir de 1905.

${ }^{55}$ HICEM é uma organização fundada em 1927 cujo objetivo era ajudar os imigrantes judeus europeus. O HICEM foi formado pela fusão das três associações de imigrantes: HIAS (Hebrew Immigrant Aid Society), estabelecida em Nova York; ICA (Jewish Colonization Association), estabelecida em Paris, mas 
HIAS, ICA e Emigdirect) em 1927, novos programas foram traçados, aumentando as responsabilidades e objetivos do HICEM. Cursos de língua portuguesa, cooperativa de crédito, associação para a defesa da Mulher e ensino profissional transformaram a sociedade numa organização global de ajuda social para todo o Brasil. Em suas viagens pelo Brasil e Argentina, Raffalovich passou a adaptar as diversas sociedades de ajuda em favor da produtividade do imigrante e proferir palestras e conferências sobre temas judaicos, procurando despertar a consciência de seus membros para a necessidade de criação de novas escolas ${ }^{56}$.

Conforme mencionamos anteriormente, como previa o projeto de colonização da ICA, a primeira escola judaica foi estabelecida em Philippson com a vinda de Léon Back, em 1908. Escola de composição mista incluía católicos, conforme depoimentos de Eva Nicolaievsky (1975). Ao que tudo indica a orientação da escola, imprimida pela JCA, era de uma instituição que pudesse facilitar a adaptação dos colonos ao novo País e com padrões do mundo ocidental, afastando-se da mentalidade do schtetel, típico da Europa Oriental.

Nos anos de 1910 já encontramos, em cidades como Porto Alegre, Rio de Janeiro e São Paulo, hedarim. Nas palavras de Falbel (2008: 338), “escolas provisórias para o ensino religioso das crianças dos imigrantes, visando acima de tudo, o seu preparo para o Bar-mitzva”. Na década de 20 é quando efetivamente criaram-se "escolas" 57 assim como as que conhecemos hoje em dia, com um programa secular inspirado nos modelos europeus do $\mathrm{Cysho}^{58}$ e do Tarbut ${ }^{59}$, sendo esta última corrente

registrada como uma sociedade de caridade britânica, e a Emigdirect, organização de imigrantes estabelecida em Berlim. O nome HICEM é um acrônimo de HIAS, ICA e Emigdirect.

${ }^{56}$ Referência sobre sua preocupação com a assimilação pode se encontrar no DIV de 23/7/1926.

${ }^{57}$ As referências sobre as primeiras escolas também chamadas de Talmud Torá encontramos nos artigos "Subsídios a história da Educação judaica no Brasil" (Falbel, N.) In: "Estudos sobre a comunidade judaica no Brasil”, Fisesp, São Paulo, 1984, pp. 119-130. No arquivo de David Perez encontra-se a referência sobre a fundação da escola Talmud Torá de São Paulo, fundada em 25 de fevereiro de 1916.

${ }^{58}$ Cysho - Central Yiddish School Organization. Referimo-nos às escolas judaicas na Polônia do início do século XX de orientação laica e antissionista que introduziram o socialismo e cultivavam o Ídiche como língua de expressão cultural no universo judaico. Era formado principalmente por judeus da classe alta que não mais se identificavam com o estilo de vida tradicional judaico de seus pais calcado na religião.

59 Tarbut - do hebraico "Cultura". Referimo-nos à rede de escolas de orientação sionista também na Polônia. Diferentemente do Cysho, identificavam-se plenamente com os ideais sionistas e privilegiavam essencialmente a língua e a cultura hebraica em sua educação. Era formado também por judeus seculares que se foram aculturando e se afastando da forma tradicional de prática judaica religiosa. 
plenamente identificada com os ideais sionistas e tendo como norma fundamental o ensino da língua e cultura hebraica.

Cabe lembrar que o $1^{\circ}$ Congresso Sionista no Brasil (1922) dedicou uma parte de sua pauta à questão da educação judaica no Brasil. O Sr. Saadia Lozinski ${ }^{60}$, que foi um dos primeiros professores no Brasil (professor no Maguen David), se posicionou a favor de uma educação tradicional e tendo o hebraico como língua reconhecida nos estudos judaicos. Ainda sob essa perspectiva, o senhor Stolzenberg apresenta a seguinte resolução: "Uma vez que a questão da educação judaica é uma das mais importantes no Brasil, resolve o Congresso Sionista recomendar à comunidade judaica - brasileira criar escolas, onde além de uma cultura universal, recebam as crianças judias uma educação moderna nacional - hebraica e religiosa". (FALBEL, 1984, p. 103-105). Para o Sr. Gewertz, por outro lado, a criança judia necessita de meios para se ligar e se unir com o judaísmo, e isto só poderia ser alcançado através da língua ídiche. A religião, segundo Gewertz, não tem mais lugar na educação. "Ídiche e educação radical são os elementos fundamentais na formação da criança israelita”. (FALBEL, 1984: 104). Mesmo tendo outros oradores que se manifestaram a favor do ídiche como um elemento da educação nacional judaica, a maioria dos congressistas apoia a resolução para que sejam implementados esforços em relação ao hebraico, a língua nacional de todos os judeus, em todas as gerações.

Nas comunidades maiores do Rio, São Paulo e Porto Alegre fundaram-se escolas judaicas, em sua maioria, de orientação laicista. Em São Paulo, a primeira escola a ser fundada foi Thalmud Torah em 1916, denominada, no jornal A Coluna, de Bet-Sefer Yvri $^{61}$, sendo seu professor de hebraico Júlio Itkis. Segundo relato de Max Fineberg em A Coluna de agosto de 1916: “O Thalmud Thorá, recentemente fundado, vai prestando inestimável serviço de instruir os filhos de nossos correligionários na língua dos profetas e educá-los propriamente para que sejam tão bons israelitas como brasileiros". A escola Maguen David, no Rio de Janeiro, (mais tarde chamada: Colégio Hebreu Brasileiro) foi fundada em 1922 e foi convidado para dirigi-la o Prof. David José

\footnotetext{
${ }^{60} \mathrm{Um}$ dos primeiros professores na cidade do Rio de Janeiro. Pedagogo de erudita formação judaica. Viera da Holanda e era um sionista convicto. Em 1922 quando se formou a Federação Sionista do Brasil foi seu primeiro vice-presidente. Foi, também, diretor da Escola Sholem Aleichem no Rio durante muitos anos.

${ }^{61}$ No número de maio de 1916 do A Coluna noticiava-se que no dia 25 de fevereiro próximo passado fundou-se na Capital de São Paulo, um Thalmud Thorá, o primeiro no Sul do Brasil de que temos notícia. A frequência em abril era de 23 alunos: 20 do sexo feminino e três do masculino.
} 
Perez $^{62}$. Ainda nesse ano foi fundado o Colégio Renascença (Hatchia) em São Paulo, no Bom Retiro, que tinha uma visão pedagógica mais avançada e atrairia pela qualidade de seu ensino e de seu corpo docente, os filhos dos israelitas da nova imigração (FALBEL, 1984, p. 114). Em 1925, no Rio de Janeiro, foram criados o Jardim de Infância e Escola da Associação Sholem Aleichem, que integrou em seu currículo o português e o hebraico, e o ensino do Ídiche no Jardim de Infância. A criação desta escola se deveu ao fato de muitos pais não concordarem com a orientação pedagógica hebraísta da escola Maguen David, apoiada esta pelas organizações sionistas, conforme relatado no Semanário (cf. DIV ${ }^{63}$ de 31/7/25 e 28/8/1925).

Nessa época buscava-se "um equilíbrio entre o currículo hebraico e o ídiche, esta última, a língua do cotidiano entre os imigrantes da Europa Oriental” (cf. Falbel, N. 2008, p. 311). Em 1928, o crescimento do Beit Sefer Ivri Brasilai (“Maguen David”), sob a direção do Professor Burlá, motivou uma mudança para um novo prédio. Nessa época começa-se a pensar no fortalecimento do ensino da língua ídiche conforme referências no Ídiche Folksteitung ${ }^{64}$ de 3/2/1928. De fato, um verdadeiro movimento entre pais e professores iniciava-se para impor o ídiche como língua a ser estudada nas escolas e com o mesmo peso e importância do hebraico (FALBEL, 2008, 342).

Em 1926, um grupo de ativistas do Poalei Sion abriu a primeira escola em Porto Alegre, denominada Ber Borochov, na linha do "Idische - veltliche folks-schul" - A escola secular - nacional judaica, seguindo a corrente do Cysho europeu ${ }^{65}$. "O programa da escola, fundada em 1927, estava assentado sobre o ídiche como língua de ensino, e o hebraico como língua para os estudos mais profundos, além do português, assim como era ensinado na escola oficial do país". (ibidem, 2008: 342).

Esse mesmo movimento levaria à criação de uma Escola Popular Judaica e Jardim de Infância no Meyer, no Rio de Janeiro, sob a orientação pedagógica do líder do Poalei Sion, Aron Bergman. Em artigo datado de 9/12/1927 no Brazilian Ídische

\footnotetext{
${ }^{62}$ Vide Falbel, N.: David Jose Pérez: uma biografia, Garamond, Rio de Janeiro, 2005.

${ }^{63}$ Referimo-nos ao periódico da comunidade israelita do Rio de Janeiro criado por Aron Kaufman em 1923: Dos Ídiche Vochenblat (O Semanário Israelita). Esse periódico durou até 1927 e em suas páginas encontramos um retrato da vida dos judeus no Brasil tendo como redatores Jacob Nachbin e José Katz.

${ }^{64}$ Referimo-nos ao periódico criado por Joseph Halevy Di Yuidische Tzukunfut (O Futuro Israelita), em sua segunda tentativa jornalística após o encerramento do primeiro periódico em ídiche Di Menscheit..

${ }^{65}$ Tanto Raizman como A. Bergman vieram ao Brasil apoiados pela corrente da Cysho dando sustentação ao movimento pró-ídiche no Brasil, conforme se pode ver no número comemorativo do Idische Presse, $\mathrm{p}$. 18-23, "Di bevegung far idische in Brazil" (o movimento pró-ídiche no Brasil).
} 
Press (Imprensa Israelita Brasileira) publicou-se uma matéria sobre "A Nazional veltliche idische folks-schule un Kinderheim" (A escola secular - nacional judaica e o lar da criança). Nesse artigo justificava-se a criação de tal escola devido ao fato de que na escola oficial centenas de crianças judias eram educadas em um ambiente onde prevalecia o espírito católico. Seguindo a mesma orientação idichista do Cysho foram criadas, ainda, em Salvador, em 1925, a escola "Jacob Dinezon"; em Santos, em agosto de 1930, a escola "I.L.Perez" e em São Paulo, foi fundada a Sholem Aleichem em $1934^{66}$. (FALBEL, 2008: 343).

Sabemos, porém, que as dissensões entre as duas correntes, a idichista e a hebraísta, levaram, na época, ao fechamento de algumas escolas, entre elas a Ber Borochov de Porto Alegre e a I. L. Perez, de Santos, como relata I. Raizman em sua obra Um quarto de século da imprensa judaica no Brasil ${ }^{67}$. Para ele, a divisão da escola de Porto Alegre foi de caráter ideológico e ele, idichista por convicção, culpa injustamente os sionistas e a obstinação do professor Jacob Faingelernt, bem como a Raffalovich pelo ocorrido. Em outro artigo, sobre o histórico da escola de Santos, "O difícil começo" (Di schvere atchile), Raizman enfatiza o papel de Jacob Faingelernt como hebraísta que não dava importância ao ensino do ídiche, o que, segundo Falbel N., não corresponde inteiramente à verdade. (Ibidem, 2008: 342).

Cabe lembrar que a ICA negou-se a subsidiar duas escolas em pequenas comunidades, fato que obrigou o rabino Raffalovich a recusar apoio financeiro a algumas escolas, gerando por parte de seus dirigentes ataques pessoais à sua imagem. Um artigo escrito por Simon Ratholz, "Der ICA forshteier un dos idische schul vezen in Brazil" (O representante da ICA e a educação judaica no Brasil), demonstrou a fragilidade das acusações. Na publicação comemorativa dos dois anos de existência da escola "I.L.Perez" de Santos (1932) encontra-se uma carta aberta dirigida à diretoria central do Instituto Cientifico Judaico (YIWO) na Europa, na qual se acusa o rabinomor representante do YIWO no Brasil como um "declarado inimigo de tudo que é judaico e secular em nossa comunidade". Os ataques pessoais a Raffalovich se repetiram nos boletins de outras escolas afiliadas à mesma corrente (Ibidem, 2008: 343).

\footnotetext{
${ }^{66}$ Vide sobre ela o artigo de Abrahão Gitelman, "Uma escola ídiche na São Paulo de trinta", in: Boletim informativo do Arquivo Histórico Judaico Brasileiro, ano III, número 17, outubro, 1999, p.7-9.

${ }^{67}$ Referimo-nos à obra de Raizman - A fertl yorhundert idische presse in Brazil, ed. Muzeum le Omanut ha-Dfus, Safed, 1968, p. 184-5.
} 
As divergências entre as duas correntes chegaram ao seu momento mais agudo entre os anos 20 e o início dos 30. Conforme encontramos no Boletim "Undzer Schul", da escola Sholem Aleichem de São Paulo, junho de 1934, p. 5, intitulado "In tzeichen fun kamf' (Sob o signo da luta), o professor A. Aizengart, que já havia passado por várias escolas desde que desembarcara no Brasil, diz que "a escola deve estar orientada para as crianças em base moderno-progressista e não sob a nacionalista estreita, clericalchouvinista concepção dos ativistas dos "presidentes" e "diretores" com o seu espírito reacionário, em todos os aspectos da educação escolar, e a tendência do profundo reacionarismo e obscuro clericalismo da ICA e seu representante Raffalovich" (Fundo 140 Abraham Gitelman, AHJB $)^{68}$.

Em outro artigo de autoria de Aharon Matz, um dos dirigentes da escola Sholem Aleichem do Rio, sob o título "Farvos idische - veltliche shulen?" (Por que escolas seculares judaicas?) publicado no boletim comemorativo da escola de Santos, apresentase a corrente escolar secular nacional-judaica como a melhor alternativa para a educação judaica. Em oposição, temos a escola religiosa Talmud Tora, que vivendo do passado da história judaica, "tira a criança do mundo que a envolve", a escola hebraica que apesar de moderna, "constrói uma muralha da China entre a criança e seus pais" educando para Eretz Israel (terra de Israel), para um futuro sem perspectiva de realizações, e a escola oficial brasileira, que ao contrário das duas anteriores - que afastam as crianças do meio no qual vivem - favorece a assimilação, com o propósito declarado de integrá-las à nação brasileira, aumentando o abismo que se cria entre a criança judia e seu lar, e eliminando qualquer vestígio de outra identidade (cf. Falbel, 2008: 344). Segundo o autor Aharon Matz, somente a idische - veltliche schul é capaz de combater a assimilação e evitar o afastamento da criança do seu meio judaico.

De fato, devido às diferenças ideológicas, na medida em que o esquerdismo se identificava com o ídiche e assumia uma postura ideológica radical ${ }^{69}$, em oposição ao hebraico, a harmonia e a união comunitária se mostravam ameaçadas por divisões internas (FALBEL, 2008: 346). Cogitava-se nessa ocasião a ideia de um encontro nacional de professores da corrente do Cysho e a criação de uma organização central

\footnotetext{
${ }^{68}$ Era comum nos anos 30 entre os círculos de esquerda, a visão de que o hebraico era uma língua sem futuro, clerical e de grupos assimilacionistas, o ídiche seria a língua que preservaria o jovem educando da assimilação e possibilitaria a herança cultural judaica acumulada através dos tempos.

${ }^{69}$ Referimo-nos ao artigo de Aron Schenker “A necessidade de uma escola judaica”, reproduzido em seu livro Vort un Tat (Palavra e ação), ed. Ykuf, Rio de Janeiro, 1959, p. 133-135.
} 
das escolas seculares já existentes no país, com o objetivo de oficializar as duas correntes. Relacionavam-se, segundo o boletim da escola J. Dinezon "Undzer Yovel", entre as escolas da corrente secular a da Bahia, a I.L. Perez de Santos, fundada em 1930, a Sholem Aleichem de São Paulo, fundada em 1934, a N. Sc. Anski de Nilópolis, fundada em 1928, a Mendele Mocher Sforim de Petrópolis, fundada em 1931, e a escola do Meyer, até o ano de 1933 sob a direção de L. Schmelzinger. (Ibidem, 2008: 345).

No final de 1928, Raffalovich, com o objetivo de evitar cisões e divisões internas que pudessem enfraquecer, em uma fase de ampliação, o número de escolas em diversos Estados, convoca todos os professores a um debate sobre a educação judaica e propõe realizar aulas e palestras sobre temas pedagógicos e técnicas de ensino. $\mathrm{O}$ "Congresso nacional sobre a educação judaica no Brasil" ${ }^{70}$ realiza-se com a participação de cerca de 30 professores representantes de 15 colégios: São Paulo, Capital Federal, Campinas, Curitiba, Recife, Bahia, Niterói, Natal, Belo Horizonte, Passo Fundo, Cruz Alta, Campos, Porto Alegre e Quatro Irmãos,

O propósito era a elaboração de um programa comum para o ensino das línguas ídiche, hebraico e história judaica, incluindo cursos pedagógicos ${ }^{71}$. O professor Moshe Weiner $^{72}$, da escola Renascença de São Paulo, foi eleito presidente desse encontro, composto de um grupo de 15 professores pertencentes ao partido Poalei Sion do total de 32 participantes. L. Schmelzinger, representante desse grupo, pregava, em sua concepção pedagógica, "total independência de ensino, o direito assegurado do ídiche e o caráter universal-popular do currículo" (FALBEL, 2008: 350). A corrente hebraísta era composta de 7 professores, sob a direção de I. Eidelman. Os demais 10 professores tinham uma posição mediadora entre ambos os grupos, fato que permitiu uma resolução igualitária para o ensino do ídiche e do hebraico. Cabe citar que uma das consequências da realização desse congresso foi a criação de um centro de professores, com o apoio de Raffalovich e a presidência de I. Eidelman, com a finalidade de cuidar dos "interesses

\footnotetext{
${ }^{70}$ Referência sobre o Congresso encontra-se no Brazilianer Idische Press (Rio de Janeiro) de 16/12/1927.

${ }^{71}$ Esse encontro é lembrado por Jacob Nachbin em seu artigo "Der moderner idicher ishuv in Brazil", publicado em setembro de 1930 no periódico Di Tzukunfunt, nos Estados Unidos. O centro da reunião foi o Colégio Hebreu Brasileiro, e as despesas pagas pela JCA, representada por I. Raffalovich.

${ }^{72}$ Moshe Weiner, pedagogo altamente capacitado, deu um impulso à escola Renascença fundada em 1922. Ao chegar ao Brasil, Moshe Weiner viveu inicialmente no Rio de Janeiro. Nessa cidade organizou no Centro Sionista cursos noturnos de hebraico, ídiche, tanach, história judaica e estudos gerais. Em São Paulo no Renascença introduz o ensino da religião sob aspecto histórico, as festas e as línguas ídiche e hebraico.
} 
dos professores, do seu preparo pedagógico, e do nível e currículo escolar das instituições de ensino" (ibidem, 2008: 304).

A partir desse congresso algumas escolas se renovaram adotando uma pedagogia mais moderna e atualizada e atraindo um número cada vez maior de alunos, como foi o caso da Folks - Schul Scholem Aleichem no Rio de Janeiro, fundada em 1928, sob a orientação do conhecido pedagogo Eliezer Steinberg e da pedagoga Lea Zacher ${ }^{73}$, vinda da Polônia com pedagogia moderna e atualizada.

Uma das dificuldades na implantação da rede escolar de escolas judaicas relatadas por I. Raffalovich, representante da ICA no Brasil, eram os sacrifícios exigidos dos professores em sua missão educacional, a instabilidade do corpo educativo e o intercâmbio requerido dos professores de uma cidade para outra.

Raffalovich, ao perceber que não havia uma literatura judaica em língua portuguesa indispensável para se implantar um programa escolar para a nova geração, traduziu os seus próprios escritos para o português ${ }^{74}$. Acreditava que "a questão da educação hebraica no Brasil não será resolvida se não se criar um programa geral para todas as escolas existentes no país e se não se fortificar os professores menos preparados para elevar o nível da educação judaica..." 75 (Falbel, 2008: 353).

Boa parte da rede atual de ensino escolar judaico no Brasil deve sua fundação aos esforços, incentivo e apoio do rabino Raffalovich. Ele viajava incessantemente com o objetivo de contatar as comunidades e de comprometer a liderança local em relação à ajuda da ICA na manutenção das escolas. Ao sair do Brasil em 1935, com destino a Eretz Israel, a rede escolar judaica contava com mais de 30 estabelecimentos de ensino fundados por ele e com o apoio financeiro da ICA.

\footnotetext{
73 Referência sobre ela, vide o IF de 10/04/1928. Lea Zacher nasceu em Kolomei, fez o ginásio na Galitzia e estudou em Viena. Lecionou na Galitzia Oriental como pedagoga e também era pianista.

${ }^{74}$ Referimo-nos ao seu livro Rudiments of Judaism (1906), traduzido posteriormente ao português em 1925, além do Anglo - Hebrew Modern Dictionary (1926) e de um volume de sermões e discursos sob o título Our Inheritance (1932). Traduziu também a história do povo judeu de Paul Goodman (1874-1949), ativista sionista inglês e escritor publicado em 1926.

${ }^{75}$ Conforme circular de 25/9/31 no qual o rabino-mor convoca um outro congresso para os professores.
} 


\subsection{Das Escolas Comunitárias de São Paulo e Suas Condições de Produção}

As escolas comunitárias de São Paulo, que constituem o nosso corpus de análise, foram fundadas por imigrantes que aqui se estabeleceram com o objetivo de dar continuidade à educação de seus filhos, pautada em valores ético-religiosos da ampla tradição judaica, da cultura e da língua de seus ancestrais. Sua essência era voltada à construção da identidade judaica. Com esse objetivo traçaremos brevemente um histórico das escolas para melhor situarmos suas condições de produção.

O Gymnasio Hebraico-Brasileiro Renascença iniciou suas atividades no dia 22 de abril de 1922, numa pequena casa alugada no bairro do Bom Retiro. Foi fundado por imigrantes originários principalmente da Europa Oriental. O Renascença, primeira escola paulistana a oferecer o diploma de primário junto ao ensino judaico, foi uma das instituições que definiu o estabelecimento de uma comunidade judaica organizada em São Paulo. Em 1937, o Renascença, Hatchia em hebraico, inaugurou sua primeira sede própria na Rua Prates, Bom Retiro, em terreno e casa doada pela família Klabin-Lafer. Entre os anos 30 e 40 consolidou-se como um dos principais centros da comunidade judaica, sede de movimentos juvenis e de atividades sociais e políticas. O Hatchia também funcionava como uma escola profissionalizante para jovens e adultos, oferecendo cursos diurnos e noturnos para os imigrantes recém-chegados da Europa que buscavam sua inserção no mercado de trabalho. Cabe acrescentar que, sob a gestão do diretor Moyses Weiner, na década de 40 foi criado um Seminário Hebraico de professores - primeiro curso regular de formação de professores para o ensino judaico e a implantação do curso ginasial. Ensinava-se o Ídiche e o Hebraico. Na década de 1958-68, com a expansão do número de alunos para além de dois mil a escola foi ampliada e foram inaugurados os cursos clássico, científico e escola normal.

Em 1980 foi inaugurado o prédio do Renascença em Higienópolis e, em 1986, sua sinagoga (www.renascenca.com.br).

O Colégio Iavne (Beit Chinuch) foi fundado em 1946 após a segunda Guerra Mundial por um grupo de judeus sobreviventes do Holocausto que vieram com o propósito de criar uma comunidade ortodoxa nos moldes da Halachá, norteados pelos preceitos milenares do judaísmo. Inspiraram-se na figura do proeminente sábio 
talmúdico Rabi Yochanan Ben $\mathrm{Zakai}^{76}$, líder do povo judeu por ocasião da destruição do Segundo Templo pelos romanos, no ano de 68 da Era Comum. Seu principal pedido depois da destruição de Jerusalém foi a criação de uma academia de estudos em Iavne para a preservação do judaísmo e do povo judeu.

Inicialmente o colégio funcionava na Rua Bela Cintra com a Rua Estados Unidos, oferecendo judaísmo complementar ao currículo escolar brasileiro. Em 1950 passa a funcionar com sede própria no lugar onde atualmente se encontra nos Jardins, tendo como presidente o Sr. Benjamin Citron. Em 1965 foi ampliado o casarão inicialmente adquirido e foi construída uma sinagoga, refeitório e uma quadra esportiva. O colégio Iavne desde o início teve como objetivo proporcionar uma educação religiosa e secular, nos moldes dos ensinamentos da Torah, segundo as normas do Talmud e de seus decodificadores, para se formar bons cidadãos e bons judeus. A língua hebraica constituía desde o início a coluna vertebral dessa instituição (www.iavne.com.br).

A Escola Bialik foi fundada em 1943 por um grupo de imigrantes recémchegados nos moldes do tradicional Cheder $^{77}$ do leste europeu. Funcionava anexa à sinagoga Beit Yacov com apenas oito alunos de diferentes faixas etárias. Tendo em vista um crescimento quantitativo, em 1955 o Bialik transferiu suas instalações para a Rua Cardeal Arcoverde. A partir dessa época proporcionou uma educação integral, enfatizando uma educação judaica voltada para as necessidades do presente. Nos anos 70 construiu sua sede própria na Rua Simão Álvares. Em 1979 foi criado o segundo grau e a escola foi declarada de utilidade pública federal. Da educação infantil ao ensino médio, o colégio Bialik vem unindo os princípios judaicos com os valores atuais da educação (www.bialik.com.br).

A associação mantenedora do Colégio I.L. Peretz foi criada em 20 de dezembro de 1948 pelo Sr. Bernardo Guertzenstein, que juntamente com a sua diretoria tinham

\footnotetext{
${ }^{76}$ O Rabi Yochanan Ben Zakai durante a rendição aos romanos pediu que fosse autorizado aos judeus o estabelecimento de uma academia de estudos em Iavne, Israel, para onde seria transferido o Sinédrio de Jerusalém (Supremo Parlamento) que fora capturado e destruído. Este sábio sabia que da preservação dos estudos dependeria a perpetuação do judaísmo e do povo judeu.

${ }^{77}$ Cheder (do hebraico "quarto"). Esta designação refere-se a aulas de religião que eram dadas, em geral, em um quarto anexo à sinagoga ou na casa particular de um melamed (professor). Tradicionalmente os meninos começavam a estudar no cheder entre três e cinco anos, aprendendo a ler hebraico em uma cartilha, Reshit Daat, e estudando o livro do Levítico, que era mecanicamente traduzido para o ídiche. As crianças passavam a maior parte do tempo no cheder, e os professores adotavam o castigo corporal com uma correia para se manter a disciplina. No mundo pré-moderno nenhuma menina frequentava o cheder. Logo após o Bar-Mitzva, o estudante trocava o cheder por uma Yeshiva (estudos de judaísmo mais avançados) ou ia trabalhar.
} 
como objetivo principal a fundação de uma sinagoga e de um local que oferecesse aos jovens atividades culturais e, desta forma, servisse de referência para a comunidade do bairro. Em 1951, a entidade fundou o Colégio Peretz, com o propósito de ampliar os estudos da sinagoga. Com o crescimento e expansão da escola foi alugado um prédio para o funcionamento do Jardim de Infância e adquirida uma casa na rua Madre Cabrini para o curso ginasial. Em 1975 foi criado o curso colegial.

Com o objetivo de envolver mais os pais no processo educacional da escola e atender suas reivindicações foi criada, em 1990, uma associação de pais de alunos do I.L.Peretz. Do Paipe (pais de alunos do Peretz) formou-se uma nova diretoria da Associação Cultural Religiosa Israelita. A fim de unificar as unidades de ensino, em 1995 foram inauguradas as novas unidades do Ginásio e Colegial e a nova sinagoga Mordechai Guertzenstein. Atualmente, o colégio empenha-se em satisfazer cada vez mais às necessidades pedagógicas, aperfeiçoando, reciclando e incentivando seus educadores e equipando suas bibliotecas e laboratórios com o que há de melhor no mercado (www.peretz.com.br). 


\section{CORPUS DA PESQUISA}

\subsection{Investigando a função da língua Hebraica no processo de ensino- aprendizagem na diáspora (retomando nossos procedimentos e objetivos)}

Nosso campo discursivo de referência da presente investigação é aquele voltado às filiações identitárias ao/ no discurso didático-pedagógico no processo de ensinoaprendizagem da língua hebraica/ língua estrangeira, tendo sido delimitado um corpus que contém sequências discursivas envolvendo questões de subjetividade, identidade / identificação, sujeito e sentido, memória e alteridade. Este tipo de corpus denomina-se em AD corpus experimental (cf. Courtine, 1981, p.27)

O corpus desta pesquisa foi constituído por sequências discursivas obtidas como resultado do nosso questionário e por depoimentos de alunos, professores e diretores no que tange à língua hebraica (segunda língua) em suas formas de subjetivação / filiações identitárias no processo de ensino-aprendizagem no atual contexto social histórico da comunidade judaica, representada em sua heterogeneidade pelas escolas comunitárias: laica / secular e religiosa.

Os entrevistados são ex-alunos, professores e diretores de escolas comunitárias de São Paulo, laica/ secular e religiosa, onde a língua hebraica é ministrada como matéria regular no currículo escolar. Não foram incluídas nesta pesquisa escolas de caráter particular como Yeshivot $^{78}$ de Rabinos ou do Beit Chabad, filiadas a linhas ortodoxas específicas cuja administração não é comunitária, ou seja, não é regida por um conselho de pais e por uma diretoria eleita pelo conselho.

Nosso recorte se concentrou em ex-alunos, professores e diretores entre os anos de 1980 a 2010. Os ex-alunos que participaram de nossa pesquisa estudaram pelo menos oito anos na escola judaica e em sua maioria são netos de imigrantes que aportaram ao Brasil no início do século XX. Quanto aos imigrantes, conforme mencionamos no capítulo anterior, em sua maioria eram ashkenazitas falantes do Ídiche, provenientes do Leste Europeu, que viviam na chamada Zona de residência do Império Czarista sem meios de subsistência favoráveis e muitas vezes sofrendo intensos

\footnotetext{
${ }^{78}$ Yeshiva Or Hatorá do Rabino M. A. Iliovits ou escola Gani do Beit Chabad. ou Beit Yaacov de meninos ou a escola Hamaor do Rav Havlin.
} 
pogroms. Já os sefaraditas, que aqui chegaram em menor escala, eram provenientes da Península Ibérica, de Portugal e Espanha. Esses judeus perseguidos pela inquisição buscaram refúgio no norte da África, Império Otomano, parte da América do Sul, Brasil, Argentina, Itália, Holanda Grécia e Turquia. Sua língua era o Judeu Espanhol (Ladino ou judezmo) nos países do Império Otomano e Hakitia no Norte da África. Também encontramos entre os nossos alunos netos de judeus orientais - מזרחים falantes do árabe, judeus não sefaraditas das comunidades do Oriente Médio e do mundo islâmico tais como Iraque, Síria, Líbano e África do Norte.

Os professores de nossa pesquisa são judeus nascidos no Brasil tendo o português como língua materna e alguns israelenses cuja língua materna é o hebraico, sendo que todos eles possuem uma sólida formação pedagógica e mais de dez anos de experiência em ensino de língua hebraica e estudos judaicos. Quanto aos diretores entrevistados são membros inseridos na coletividade judaica de São Paulo, atuantes e participativos com uma sólida formação na área educacional e judaica.

Cabe ressaltar que, ao trabalharmos com a língua hebraica na diáspora, estamos nos referindo a processos de subjetivação e de filiação que perpassam por determinações diferentes dos judeus sabras e judeus residentes no Estado de Israel. Os sabras, cidadãos israelenses nascidos em Israel, mantêm uma relação linguísticocultural com a língua hebraica pautada pela ideologia sionista decorrente do renascimento nacional judaico que veio a se contrapor ao antigo "judeu da diáspora". O Estado de Israel instituiu a língua hebraica como língua oficial e nacional desde o seu ressurgimento, bem como um calendário oficial que segue todas as datas religiosas e cívicas do Estado judeu.

Assim estabelecemos em nossas análises três seções: uma concernente à subjetividade dos professores, a outra dos alunos e a terceira dos diretores da escola, a fim de apreendermos os momentos em que se produzem relações de heterogeneidade no interior desta FD, bem como os saberes que identificam tanto os sujeitos religiosos como os laicos /seculares. Quanto ao discurso dos diretores estamos cientes que este reflete o contexto político de sua atuação.

Optamos por um questionário segundo critérios temáticos, autorizados nessa prática pela concepção de descontinuidade de saberes respaldada pelo aporte teórico da Análise do discurso. Privilegiamos perguntas referentes à identidade/ identificação, memória e sentido atribuídos à língua hebraica no atual contexto escolar judaico. (cf. anexos na última página) 
Conforme mencionamos anteriormente, não pretendemos trabalhar com todos os depoimentos e respostas produzidas a partir de nosso questionário e que formam nosso corpus discursivo, mas sim com sequências discursivas selecionadas: recortes produzidos a partir do nosso questionário aos alunos, professores e diretores de escolas comunitárias de São Paulo, que entendemos como representativos para a questão da filiação identitária no processo aprendizagem da língua hebraica na escola laica /secular e religiosa. Nossos objetivos consistem, portanto, em identificar, através de recortes das falas desses grupos, filiações simbólicas, imaginárias, que constituem seus processos de identificação com a língua hebraica no processo de ensino-aprendizagem.

Cabe ressaltar que a formação discursiva didático-pedagógica será aqui considerada enquanto uma "unidade dividida, uma heterogeneidade em relação a si mesma" (Courtine, 1982, p. 245), ou seja, consideraremos aqui a contradição, como seu princípio constitutivo. Não se trata, portanto, de estabelecer nela diferentes tipos de discursos derivados da individuação de diferentes grupos sociais que adquirem particularidades próprias em seu discurso - e que possibilitam, através do léxico e da sintaxe, o reconhecimento contrastivo de grupos como uma "unidade" resultante da individuação, adotada nos primeiros anos da década de 1980 em análises na AD. Aqui nos referimos ao deslocamento da noção de contraste para o da categoria de contradição estabelecida na AD (cf. Pêcheux, 1997-b, Courtine, 1981, Orlandi, 1996) que nos possibilita uma base de análise discursiva que aqui adotaremos. Buscamos em nossa análise mostrar como o funcionamento discursivo dos alunos e dos professores permite refletir acerca do seu próprio processo identitário.

O nosso desafio, ao trabalharmos com a formação discursiva didáticopedagógica, é, pois, identificar e caracterizar como o modo de inscrição do sujeito aprendiz e professor na ordem do simbólico inscrevem-se na ordem do real. Esta inscrição enquanto um espaço de determinação caracterizado por processos discursivos que intervêm no processo de significação, aí se movimentando e sendo capaz de explicar o trabalho da base linguística relacionado aos processos através dos quais os sujeitos são interpelados pelo saber do sujeito universal, isto é, pelas instituições (escolas) que representam formações ideológicas judaicas. 


\subsection{Primeira Seção: Professores}

Partimos do pressuposto de que o discurso dos professores sobre a língua hebraica perpassa por outros vários discursos que, entrelaçados na tessitura linguística, perpassam pela memória, pelo sujeito cindido descentrado heterogêneo, constituído por inscrições de sentido a partir de determinações ideológicas e subjetivas inconscientes que deixam entrever aspectos de identidade e suas identificações. Nessa perspectiva sentidos e sujeitos são produzidos discursivamente na história, dispersos em discursos heterogêneos e atravessados por uma memória do dizer (PÊCHEUX, 2002; ORLANDI, 2002).

Aqui pensamos a memória em relação ao discurso e nessa perspectiva a tratamos como interdiscurso. Este é definido como aquilo que "fala antes, em outro lugar, independentemente", conforme Henry (1992). O saber discursivo que faz com que, ao falarmos nossas palavras, façam sentido. Não se trata da memória em sua concepção psicologista de memória individual, nem tampouco do inconsciente coletivo. Trata-se, pois, da noção de memória social inscrita no seio das práticas discursivas.

Nesta seção, interessa-nos refletir como se instituiu a memória social sobre a língua hebraica no processo de ensino-aprendizagem dos professores, considerando a mediação imaginária e a dimensão simbólica. (cf. Serrani, 1988). Como foi sua memória regulada, conservada, rompida, deslocada ou restabelecida. De que modo os processos identificatórios decorrentes de filiações sócio-históricas e memórias preponderantes constitutivas do /no sujeito foram inscritos ou não na memória, como foram absorvidos por ela ou produziram rupturas. Em suma, como o trabalho de uma memória coletiva no seio de uma formação discursiva permite: a lembrança, a repetição, a refutação, mas também o esquecimento desses elementos de saber que são estruturantes de seu processo identitário, e de que forma se materializam esses saberes de memória. Sobretudo sob que formas se materializam esses saberes de memória. Buscamos, pois, refletir os efeitos de memória da língua hebraica pela dialética da anterioridade e atualização, visando apreender algo que ela sempre deixa em seus rastros ainda que lacunares, pois, no caso especifico da língua hebraica, esta esteve sempre sujeita às interdições, às coerções, aos flagelos que as "políticas de Estado", tanto no Oriente, como no Ocidente, impuseram ao povo judeu. (ídiche, judeu espanhol, judeu árabe) 
Cabe aqui mencionar que em seu livro Zakhor - História Judaica e Memória judaica, ${ }^{79}$ Yerushalmi (1992) nos chama a atenção para o fato de que na Torah o verbo zachar ( זכר ), "lembrar”, aparece 169 vezes. Ou seja, na tradição judaica: "Assim como Israel é ordenado a se lembrar, é ordenado a não esquecer".

\section{Escola Religiosa}

Qual a importância que você atribui ao aprendizado do hebraico como matéria regular na formação do seu aluno? E qual é a importância no atual contexto histórico de aprender outras línguas para seu aluno (inglês, espanhol, francês, etc)?

ER SD1. A língua hebraica como qualquer outra língua estrangeira é importante, pois amplia os horizontes, fortalece a cultura, e o hebraico em particular torna-se importante para alunos que estudam mais profundamente a Torah (Bíblia Sagrada) no Lashon Hakodesh. Dada a velocidade de informações mais acelerada, a interação entre os povos e as facilidades de intercambio entre eles, ter o conhecimento de várias línguas prepara o estudante para viver melhor na sociedade atual.

Na SD1 o ensino da língua hebraica como qualquer outra língua estrangeira amplia os horizontes do aprendiz e fortalece a cultura relacionada à mesma. Para este professor-enunciador ter conhecimento de várias outras línguas facilita a interação do aluno no mundo atual. No entanto, destaca que o hebraico em particular é importante para os estudos da Torah (Bíblia Sagrada) no Lashon Hakodesh - na Língua Sagrada.

Conforme se pode observar acima, "o hebraico, como qualquer outra língua é importante, pois amplia os horizontes, fortalece a cultura”. Enfatiza, entretanto, este professor que a importância maior do estudo da língua hebraica reside no aprofundamento do estudo da Torah (Bíblia Sagrada) escrita na Língua Sagrada Lashon Hakodesh. A língua hebraica em que foi escrita a Torah é aqui apreendida enquanto uma língua sagrada - Lashon Hakodesh - considerada muito além de uma língua vernácula que porta em si a cultura de um povo.

O pré-construído "Lashon Hakodesh" (língua sagrada) é oriundo de uma tradição em que o hebraico é a língua sagrada, com a qual D’us criou o mundo, e cujo alfabeto mantém um poder criador para aqueles que sabem combinar suas letras.

\footnotetext{
${ }^{79}$ Referimo-nos a Yosef Chaim Yerushalmi, historiador judeu que explorou o relacionamento entre a história e a memória.

80 Segundo Henry (1992), tais pré-construídos é que fornecem a matéria-prima do "sempre já aî" histórico-social, e que se produz na memória deste enunciador enquanto um jogo simbólico que sustenta a sua relação identitária.
} 
Tradicionalmente, essa determinação é assim entendida pela corrente da mística judaica conhecida como Cabala, que tem como seus fundadores sefaraditas que saíram da Espanha após a expulsão em 1492, tais como José Caro (1488-1575), codificador da lei ritual, o Shulchan Aruch, ${ }^{81}$ que se tornou o mais autorizado texto haláchico - tradição legalista do judaísmo para os sefaraditas.

Para este enunciador-professor, as rupturas, descontinuidades, as ressignificações e a própria revitalização da língua hebraica no atual Estado de Israel são aspectos culturais nacionais que podem fortalecer e ampliar o conhecimento do aluno-aprendiz de igual valor a qualquer outra língua-nacional estrangeira. A singularidade, entretanto, do ensino da língua hebraica para ele reside no aprofundamento do saber religioso escrito na língua sagrada.

A apropriação da Torah - enquanto "Bíblia Sagrada" - e da língua hebraicaenquanto Lashon Hakodesh ("Língua Sagrada") - como pré-construídos correntes na tradição judaica fazem presidir nas enunciações deste professor discursos decorrentes da memória discursiva judaica ressignificada enquanto um objeto religioso-sagrado. Para Pêcheux (1999), pensar o papel da memória numa perspectiva discursiva é pensar " $a s$ condições (mecanismos, processos...) nas quais um acontecimento histórico (um elemento histórico descontínuo e exterior) é susceptível de vir a se inscrever na continuidade interna, no espaço potencial de coerência própria de uma memória". (PÊCHEUX, 1999, p. 49-50).

Daí entendermos que o sujeito afetado pelo inconsciente e pela ideologia... " $a$ o apropriar-se dos saberes, o faz a partir da ilusão de que tais saberes se originam nele mesmo quando de fato, eles representam os "já ditos" que foram produzidos em outros discursos, em outros lugares" (PÊCHEUX e FUCHS, apud Indursky, 2003, p. 102). Essas repetições, tomadas em sua dimensão vertical, dessintagmatizadas, deslinearizadas, são inscritas no discurso do sujeito. Este, ao se apropriar das repetições, dá-lhes uma dimensão horizontal, sintagmatizada, de tal forma que, em sua repetibilidade, imprime sua singularidade na formulação.

\footnotetext{
${ }^{81}$ Do hebraico - mesa posta -. O mais autorizado código da Halachá, escrito no séc. XVI por José Caro como um manual para o leigo e para jovens estudantes. Caro seguiu em geral a linguagem e a formulação de Maimônides, um dos maiores codificadores sefaraditas. Moisés Isserles, um polonês contemporâneo de Caro, escreveu os seus próprios comentários à obra, exprimindo a posição ashkenazita. Estas duas partes da obra "Mesa Preparada" e "Toalha de Mesa" foram subsequentemente impressas juntas, tornando o código conjunto amplamente aceitável para a maioria da comunidade judaica.
} 
Cabe, entretanto, aqui lembrar que a língua hebraica foi preservada pelo povo judeu como fator de identidade por mais de três mil anos. Já séculos antes da era comum, a maioria dos judeus da região de Canaã falava o vernáculo, que era usualmente um dos dialetos aramaicos. A partir do século VI após a clausura do Talmud, o hebraico Mishnaico espalhou-se gradativamente por todas as comunidades judaicas dispersas pela Ásia, África do Norte e Europa e desde aproximadamente 900 D.E. C. até o seu renascimento em 1880, o hebraico era usado não somente como língua passiva de estudo de orações, mas como também para ativa comunicação em documentos legais e cartas particulares (RABIN, C., 1970). Em 1880 D. E. C., com a imigração de Eliezer Ben Yeuda ${ }^{82}$ para Israel, a língua hebraica foi restaurada como língua falada e conhecida como "língua revitalizada". A língua hebraica em sua estrutura moderna pode ser definida como uma fusão de línguas, formada por componentes clássicos do hebraico bíblico, Mishnaico, medieval e do aramaico babilônico, juntamente com substratos da língua ídiche (cf. Kutscher, 1982).

Qual é a importância que você atribui ao aprendizado do hebraico como matéria regular na formação do seu aluno?

חשיבות השפה העברית היא גדולה, עשום שהיא מקשרת אותו לעם היהודי, לשפה הקדומה, לאבות אבותיו מהימים ההם, לשורשים העמוקים של ימי קדם, ובעיקר לימים האלה, למדינה היהודית הקיימת שבה מדברים בשפה העברית, ומביאים לידי ביטוי את ההסטוריה של העם היהודי לדורותיה וקיומו הבלתי מוגבל של העם. כך, עם ידיעת השפה היהודית, מתחזקת הזהות היהודית, מתחזק הקשר הציוני.

והרי ישנם גויים רבים הלומדים במוסדות שונים את השפה העברית. האם בכך גם הם נקשרים לעם היהודי? היכן שהוא כן, אבל בהשאלה. אין להם את הקשר העמוק מתוך העם, אלא רצון להכיר אותו ואולי לנסות לחקותו...

ER SD2. A importância da língua hebraica é grande, uma vez que ela está relacionada ao povo judeu, a sua língua ancestral, língua de seus patriarcas e antepassados, as profundas raízes da antiguidade, e, sobretudo, aos dias atuais, a existência do "Estado Judeu" onde a língua hebraica é falada e através dela é expressa a história do povo judeu através de suas gerações e a permanente existência do povo

${ }^{82}$ Eliezer Ben Yeuda (1858 D.C. - 1922 D.C.) é considerado o pioneiro da fala hebraica. Contribuiu de forma significante para o renascimento da fala hebraica na época moderna. Além de criar um grande número de novos vocábulos, logo adotados em Israel, elaborou o seu grande Dicionário, composto de dezesseis volumes, no qual introduziu o vocabulário hebraico de todos os períodos históricos, acrescidos dos termos inovados pelos iluministas e por ele mesmo. 
judeu. Dessa forma com o conhecimento da língua judaica se fortalece a identidade judaica, se fortalece a ligação com o Sionismo. Tantos gentios estudam a língua hebraica em várias instituições. Sendo assim, estariam eles ligados ao povo judeu? E mesmo que a resposta seja positiva, sua ligação é emprestada, uma vez que não possuem a ligação forte que emana do povo judeu. Sua vontade é conhecê-lo ou talvez simplesmente imitá-lo. (Tradução minha).

Como se pode observar este professor-enunciador remete a importância da língua hebraica às antigas raízes históricas do povo de Israel, conforme mencionadas na Torah. Estabelece uma relação entre a língua ancestral, língua de seus antepassados na antiguidade e a existência do "Estado Judeu” atual, onde a língua judaica é falada.

A SD2 coloca em questão a manutenção da língua hebraica face aos acontecimentos históricos do povo judeu na antiguidade mencionada na Torah, a língua ancestral falada pelos patriarcas fundadores da fé judaica e a existência atual do "Estado Judeu" em sua ligação ao sionismo. Como segue: "ao povo judeu, a sua língua ancestral, língua de seus patriarcas e antepassados (...) e, sobretudo, aos dias atuais, a existência do "Estado Judeu”. Para ele o conhecimento da "língua judaica" fortalece a “identidade judaica” e consequentemente fortalece a ligação com o sionismo. A "língua judaica" - o hebraico - falada no atual Estado de Israel, para este enunciador está intimamente relacionada à antiguidade, a língua ancestral judaica falada pelos patriarcas. O conceito de "Estado Judeu" destacado em sua fala remete à nação dos judeus desde os tempos bíblicos (Reis) até aos nossos dias. Quanto ao sionismo estabelece uma íntima ligação entre a nação judaica na terra de Israel e a língua judaica falada pelos seus ancestrais.

Como se pode observar, este enunciador, na mesma medida em que dá destaque à identidade judaica alicerçada na língua ancestral falada pelos patriarcas na época bíblica, não estabelece distinção entre processos históricos relacionados à trajetória da língua que remontam ao exílio (escravidão, perseguições religiosas, proibição de culto, ou seja, interdições na língua) e a acontecimentos, a partir dos quais o êxodo e a permanência na diáspora não estão afetados por perseguições ou por proibições (descontinuidades e assimilação com outras culturas) ao longo da história.

As designações: "Estado Judeu" e "sionismo" enquanto viver em Eretz Israel (terra de Israel) remetem a pré-construídos retirados da tradição judaica oral e escrita, conforme princípios nacionalistas de nossos sábios acerca do mandamento da nossa obrigação moral de viver em Eretz Israel (Terra de Israel). "Viver em Eretz Israel é 
equivalente a todas as mitzvot da Torah" (cf. Sifre, Parashat Ree, Tosefta Avoda Zara $5)^{83}$ ou ainda cf. Talmud Ketuvot 10).

Dessa forma, para este enunciador o estudo da língua hebraica atual está intimamente relacionado com a "língua judaica" do povo judeu e de seus ancestrais, língua da antiguidade falada na antiga "Terra de Israel” (Eretz Israel). Um gentio, ao estudar a língua hebraica nas diversas instituições onde a mesma é ensinada, não poderia se ligar ao povo judeu diante de suas profundas raízes históricas solidificadas na antiguidade em sua língua ancestral. Somente poderia querer imitá-lo conforme mencionado acima: "sua ligação é emprestada, uma vez que não possui a ligação forte que emana do povo judeu. Sua vontade é conhecê-lo, ou talvez simplesmente imitá-lo".

Parece-nos a propósito desse recorte sobre a ilusão da língua una, da razão universal, da possibilidade de identificação a um eu inteiro (sonho habitável que alimenta a humanidade para todo e para sempre) excluindo o diferente, o disperso, a heterogeneidade de toda a linguagem, citar Derrida (2001) em seu livro " $O$ monolinguismo do outro ou a prótese de origem".

Para este autor não há língua de origem, língua pura única, perfeita e circunscrita, a não ser na idealização do sujeito, na invenção do imaginário, responsável pela ilusão do conflito constitutivo de toda a subjetividade. Toda língua é atravessada pelo outro, assim como todo sujeito. Para Derrida (2001, p.93). Só há língua de chegada: "Não há senão línguas de chegada, [...] mas línguas que, singular aventura, não chegam a chegar, uma vez que não sabem mais de onde partem, a partir, de onde falam , e qual é o sentido de seu trajeto”. O desejo do sujeito de uma língua transparente, que dela se pode servir a qualquer momento, que se pode controlar de modo intencional é a promessa.

"Ora jamais esta língua, a única que assim estou votado a falar, enquanto falar me for possível, e em vida e na morte, jamais esta língua única, estas a ver virá a ser minha. Nunca na verdade o foi.... Sim eu não tenho senão uma língua, ora ela não é minha”. (DERRIDA, 1996, p. 14). Para Derrida não há propriedade natural da língua. Monolinguismo língua una e única, que significa "prótese de origem" é colocada no lugar da origem para sanar o furo, a falha a origem, portanto inventada, construída, falsificada,... (cf. Coracini, M., 2007, p 48).

\footnotetext{
${ }^{83}$ Referimo-nos ao livro La Mitzvá de vivir en Eretz Israel, Beer Sheva, Instituto Beit Yosef, Eretz Israel, 5765 .
} 


\section{Escola Secular / Laica}

EL SD3. Considero ser muito importante o estudo da língua hebraica, como elemento fundamental na formação da identidade judaica dos nossos alunos, além de ser um fator preponderante na garantia de continuidade do judaísmo. Aprender várias línguas ou uma segunda língua contribui para ampliar o repertório cultural dos alunos. No mundo globalizado, onde o inglês vem se tornando a língua franca, conhecer outras línguas, no entanto, vem sendo visto como um diferencial na formação pedagógica e profissional dos indivíduos.

Já na SD3 a língua hebraica é tomada como fator fundamental na formação da

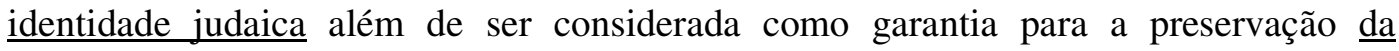
continuidade do judaísmo. Destaca este enunciador, no fio do discurso, no nível do dizer, a preservação do judaísmo e sua singularidade através da continuidade do ensino da língua hebraica. Cf. citação: garantia da continuidade do judaísmo.

Dentro da nossa perspectiva de memória discursiva enquanto um espaço de constituição/rearranjo de sentidos, os saberes contidos na língua hebraica aqui funcionam de modo dialético para este enunciador. Cf. Achard (1999:16): "entre a repetição e a regularização de sentidos, de tal forma que a regularização se apoia necessariamente sobre o reconhecimento do que é repetido." Assim, pensamos que para este enunciador os sentidos que preenchem esta enunciação, que enfatizam a preservação da identidade judaica e sua continuidade através da língua hebraica, se produzem em sua memória como um jogo simbólico que sustenta sua própria relação identitária com o judaísmo. O ensino de outras línguas serviria para ampliar a cultura do aprendiz. $\mathrm{O}$ inglês serviria como um valor agregado, um diferencial à sua formação pedagógica e profissional uma vez que se tornou a língua franca no mundo atual.

Quando se fala de identidade de um grupo, ou mesmo de um povo, pretendemos encontrar traços que possam caracterizá-la enquanto uma unidade estável, una, idêntica a si mesma. Procuramos evidenciar sua diferença com outro grupo social, no entanto mantemos ilusoriamente uma relação de homogeneidade. Na perspectiva da AD todo processo identitário é constituído por uma falta (o diferente) e pelo desejo de completude (o mesmo). Esse é o movimento das identidades.

Na perspectiva de Derrida "Uma identidade não é nunca dada, recebida ou alcançada, não, suporta-se apenas o processo interminável, infinitamente fantasmático da identificação” (Derrida, 1996, p. 43). Derrida aborda a questão da identidade como um sentimento de ilusão. "A nossa questão é sempre a identidade. O que é a identidade, 
conceito de que a transparente identidade a si é sempre dogmaticamente pressuposta por tantos debates sobre o monoculturalismo ou sobre o multiculturalismo, sobre a nacionalidade, a cidadania, a pertença em geral?" (Derrida, 2001, p. 27)

Identidade? Una? A não ser na promessa sempre adiada da coincidência consigo mesmo, do pertencimento imaginado e inventado a uma nação, a um grupo que se parece ou assemelha aqueles que são desiguais. Pertença? Inteira? Este mesmo efeito é produzido na língua e pela língua o simulacro da homogeneidade, da unidade. Não há identidade possível, a não ser na ilusão, promessa na esperança, numa racionalidade, numa totalidade jamais alcançada. Nas palavras de Coracini (2007): Promessa que é dívida impossível de ser quitada, que é esperança numa racionalidade, numa totalidade jamais alcançada, lugar inacessível da segurança e da certeza, longe da dúvida e do conflito... (cf. Coracini, 2007, p. 49). Essa promessa ou se quisermos essa ilusão (cf. Derrida, 1996) apontada pelo enunciador-professor sobre a identidade sobre o pertencimento imaginado; criado a uma nação, a um grupo que se iguala ou assemelha aqueles que são desiguais, inassimiláveis é próprio da racionalidade jamais alcançada da identidade homogênea.

Qual a importância que você atribui ao aprendizado do hebraico como matéria regular na formação do seu aluno?

EL SD4. Em minha opinião o ensino de língua hebraica é estruturante na formação judaica de nosso aluno. Através desta, o jovem se conecta e constitui elo com o Estado de Israel atual; permite o acesso à liturgia em sua forma original (hebraico) que lhe possibilitará um viver judaico (leitura do Sidur ${ }^{84}$, Torah etc.).

A SD4 atribui ao ensino da língua a própria estruturação judaica do aprendiz. Em sua formulação, este enunciador tem uma visão de que a língua não se constitui em tão somente um instrumento de comunicação, mas na / pela língua hebraica é que se estrutura a própria formação judaica, ou seja, a estruturação do indivíduo enquanto pessoa.

A língua hebraica enquanto estruturante da própria formação judaica do aprendiz remete este enunciado a duas ordens de memória. Por um lado, a língua hebraica vem a se constituir como um elo entre a diáspora, lugar onde reside o aprendiz, e o Estado de Israel. Diferentemente da $\mathrm{Sd} 2$ em que a importância do ensino da língua hebraica

\footnotetext{
${ }^{84}$ Sidur aqui se refere ao livro de orações diárias que cabe ao judeu proferir ao despertar pela manhã, ao anoitecer e nas datas comemorativas designadas como Yom Tov.
} 
remete à língua ancestral, dos patriarcas da antiguidade em sua ligação ao Estado Judeu, aqui para este enunciador a língua hebraica é o elo entre as línguas judaicas faladas no exílio e na diáspora (ídiche, ladino, ou os jargões árabe-judaicos), consideradas aí suas interdições, descontinuidades e assimilação com outras culturas ao longo da história e a sua continuidade no atual Estado de Israel. Por outro lado, acrescenta que o aprendizado do hebraico também permitirá aos alunos da diáspora o acesso à liturgia em sua forma original, que lhe possibilitará um viver judaico (leitura do Sidur, Torah etc.).

Entendemos que estas repetições sobre a língua hebraica ocorrem pelo viés do processo discursivo entendido por Pêcheux (1997 b) como um sistema de substituições, paráfrases, sinonímias etc. Vale dizer que a paráfrase é constitutiva dos efeitos de sentido (cf. Pêcheux, 1997-b, p. 160-164), mas seu sentido não existe em si mesmo, ao contrario, é determinado pelas posições ideológicas que estão em jogo no processo sócio-histórico, no qual as palavras e expressões são produzidas e sustentadas por aqueles que a empregam. Assim, acreditamos que para este enunciador a língua hebraica se inscreve em uma posição ideológica identificada com o sujeito que conjuga a língua hebraica como um instrumento necessário para entender os valores éticomorais contidos na literatura clássica do judaísmo, bem como em sua liturgia, e constitui um elo para se aproximar do atual Estado de Israel, que adotou a língua hebraica moderna como sua língua oficial.

\subsection{Segunda Seção: Alunos}

\subsubsection{Segunda Língua e a Constituição das Subjetividades}

Moi j’ aime ma langue. Mais ce quoi ma langue Avoir une langue à soi comme on a une langue chambre à soi.

Avoir une langue et qui plus est une langue maternelle, une langue natal. Langue de la mère, langue des ancêstres, de la famille, langue du roman familial?

E les langues autres, les autres langues, la langue des autres, l'autre de la langue, l'autre dans la langue .Et la langue et l' élangue? Aujourd'hui ce serait plutôt la déglangue ou la disneylangue .

Régine Robin, Le deuil de l'origine.

Une langue en trop, la langue en moins.

Eu amo minha língua, mas o que é minha língua? Ter uma língua própria como se tem o próprio quarto. Ter uma língua e que é antes uma língua materna, uma língua natal. 


\section{Língua da mãe, língua dos ancestrais, da família, língua do romance familiar? \\ E as línguas outras, as outras línguas, a língua dos outros, o outro da língua, o outro \\ na língua (...) Hoje seria mais (...) a disneylíngua. \\ (Tradução de Serrani Silvana)}

Nessa seção interessa-nos permear os processos de subjetivação do sujeitoaprendiz da língua hebraica/ segunda língua e de sua relação com outras línguas. Nesse processo a questão do sujeito, a identidade e a própria aquisição de língua em seu correlativo no processo aprendizagem de segunda língua são fundamentais (cf Serrani, S, Revuz, C., 2001, Coracini, M., 1995, Grigoletto, M., 2003)

Para melhor entender o ser entre línguas e, portanto, entre culturas, baseamo-nos em autores que estudaram o referido processo como Revuz (2001), Derrida (2001), Robin (2003).

Quanto ao sujeito e ao sentido questionamos um sujeito cartesiano, logocêntrico, dono de seu dizer, uno e igual a si mesmo. Adotamos uma abordagem discursiva em que se questiona de forma radical o sujeito intencional entendido como fonte individual de um sentido que lhe seria transparente (cf. Authier-Revuz, 1998, p.87).

Com base nesses pressupostos lançamos mão de conceitos de identificação produzidos na teoria psicanalítica e das categorias de interdiscurso e intradiscurso, tais como propostos por Michel Pêcheux (1997 b) por questionarem a noção de comunicação e o sujeito intencional dono de seu dizer.

Nessa perspectiva a constituição de sentido que os enunciadores imputam à língua hebraica e se constituem como sujeitos perpassa por outros discursos do interdiscurso do domínio do repetível (do já dito, da memória discursiva). A memória discursiva, conforme mencionamos anteriormente, não deve ser confundida com a memória cognitiva ou individual psicofisiológica, mas enquanto um espaço de estruturação dos contextos vividos; memória social inscrita em práticas discursivas provenientes da rede de discursos que se entrelaçam e se mesclam e, portanto, sofrem modificações e ressignificações por provir do outro. Cabe aqui lembrar que a alteridade discursiva no quadro das categorias da Análise do Discurso se situa no nível do interdiscurso, este entendido como o conjunto do dizível que necessariamente remete ao exterior (formado por outros discursos), que determina o que é formulável ideologicamente em um discurso determinado (cf. Pêcheux, 1997-a, 1997-b e Orlandi, 2002, Guimarães, 1995). 
Segundo Courtine (1981) com base na teorização de Foucault (2004) é no interdiscurso que se encontram os enunciados da ordem do repetível. Os enunciados são da ordem do repetível, enquanto as formulações se esgotam no tempo e espaço em que são ditas. Nesta dimensão de subjetividade não é o falante que encontraria na linguagem um instrumento para exprimir suas intenções de comunicação, mas o espaço do sujeito afetado pelo pré-construído e pelo discurso transverso, sujeito do inconsciente efeito de linguagem, ser em línguas, pego na ordem simbólica que o produz enquanto sujeito. (SERRANI-INFANTE, 2001, p. 245). É nessa perspectiva também que postulamos a heterogeneidade constitutiva do sujeito, o que resulta em seu descentramento, dispersão e contradição.

Cabe aqui acrescentar que na perspectiva da psicanálise, Lacan (1998) postula que a verdade sobre nós mesmos construída no nosso imaginário provém inevitavelmente pela imagem do outro, ou seja, nos vemos inevitavelmente pelo olhar do outro, cujo discurso nos perpassa e nos constitui como sujeitos, verdade com a qual nos identificamos enquanto sujeitos da linguagem. Para Lacan, com a entrada no campo da linguagem opera-se uma divisão subjetiva no aparelho psíquico que se marca na própria fala enquanto materialização da linguagem: ao falarmos, dizemos mais do que supomos dizer, pois na fala se inscreve um saber inconsciente.

Foi relendo e ressignificando o signo saussureano que Lacan introduziu a noção de significante ${ }^{85}$, o elemento que constitui o inconsciente, que tem precedência sobre o sentido e que vem do Outro ${ }^{86}$. Para a psicanálise lacaniana, lingua (gem) é uma estrutura na qual o sujeito humano, para advir como sujeito, é necessariamente inscrito, e nessa sua inscrição no campo do Outro, algo falta. "O inconsciente é estruturado como uma linguagem" (LACAN, 1988 p. 194), e nessa estruturação algo falta e se encontra silenciado. Inicialmente, o sujeito é falado, fala-se dele e nesse processo ele se encontra alienado, ou seja, submetido à ordem significante, mas, ao mesmo tempo, o sujeito retorna ao Outro ao se tornar um ser de linguagem. (ibidem: 1988, p. 196). É a

\footnotetext{
${ }^{85}$ Para Lacan o sujeito é um efeito do significante. O significante produzindo-se no campo do Outro faz surgir o sujeito de sua significação (Cf. Lacan, 1964, p 196-197). Um significante é uma entidade estritamente formal, indiretamente referida a um fato observável, que consiste num equívoco ou num ato involuntário na conduta consciente de um indivíduo. Um significante nunca existe sozinho, é sempre um dentre outros. Para Lacan um significante só é significante para outros significantes (Cf. J. Nasio, 1997, p. 111-112).

${ }^{86}$ Refiro-me, aqui, ao grande "Autre" lacaniano - isto é, o simbólico, o Outro da linguagem, "tesouro de significantes", o inconsciente enquanto "discurso do Outro" (Lacan, 1998, p. 529; cf. Le Gaufey, 1996, p. 186).
} 
possibilidade de inscrição desse significante advindo do campo do Outro, porém não aprisionado a significações, ou melhor, precedendo ao sentido, que constitui a subjetividade: "a estrutura de linguagem preexiste; o inconsciente é a sua condição." (LACAN, 1998. p. 26).

Ao nos apoiarmos em conceitos de identificação retirados da psicanálise, gostaríamos de lembrar que a crítica estabelecida por Pêcheux à linguística saussureana (1988 [1975]) tem seus fundamentos a partir de uma reterritorialização de noções do materialismo e da psicanálise. É sempre bom lembrar que para Pêcheux, "a ordem do inconsciente não coincide com a da ideologia, o recalque não se identifica nem com o assujeitamento nem com a repressão, mas para este autor isso não significa que a ideologia deva ser pensada sem referência ao registro inconsciente." (PÊCHEUX, op. cit., p. 301).

Para fins específicos de nosso estudo, serão aqui analisadas algumas sequências discursivas selecionadas e depoimentos do nosso corpus discursivo: recortes produzidos a partir de respostas formuladas no nosso questionário e depoimentos que entendemos como representativos para a questão da filiação identitária/ identificação e da subjetividade dos sujeitos aprendizes no processo aprendizagem da língua hebraica.

Designaremos a escola religiosa com a sigla ER e a secular laica com a sigla EL.

\section{Escola Religiosa}

\section{Saber hebraico significa o que para você? E saber outras línguas estrangeiras?}

ER SD1. Saber hebraico me dá certa sensação especial, coisa que as outras línguas não me dão. Poder falar a mesma língua que nossos patriarcas falavam; a língua em que estão escritos os Sifrei Torah, a Safá Kedosha. Lógico que saber outras línguas é de extrema importância, mas para mim, não tanto quanto o hebraico.

Conforme se pode observar na SD1, para este aluno-enunciador, saber a língua hebraica provoca uma sensação especial por ser esta a mesma língua falada pelos "patriarcas", a mesma língua em que estão escritos os Sifrei Torah - o Pentateuco, a Safá Kedosha - a língua sagrada. Os "patriarcas", tomados enquanto um acontecimento fundador na história judaica, juntamente com os "Livros da Torah" e a "Língua Sagrada" são os elementos significantes nessa enunciação. Abraão, segundo a Bíblia, é o grande líder dos hebreus, é considerado o primeiro patriarca, o primeiro judeu que pratica e funda o monoteísmo. Vivia em um contexto totalmente pagão politeísta, 
abandonou sua terra dirigindo-se à terra prometida por D'us. (Gênesis, 12:2). Abraão e seus descendentes Isaac e Jacob são os patriarcas que deram origem aos filhos de Israel (Bnei Israel), ao povo judeu e falavam a língua hebraica.

No caso acima, o enunciador-aluno toma uma posição enunciativa decorrente de filiações sócio-históricas e da memória preponderante sobre a língua hebraica enquanto uma língua ancestral, língua sagrada escrita no Pentateuco, motivo pelo qual reforça sua importância diante das demais línguas estrangeiras.

As unidades linguísticas aqui mencionadas "Sifrei Torah" e "Safá Kedosha" em referência à santidade da língua hebraica tratam da dimensão vertical interdiscursiva de uma rede de formulações capazes de serem reformuladas não apenas no intradiscurso em uma relação horizontal, mas também, segundo Courtine (1981, p. 102-103), em uma relação vertical, no nível do interdiscurso onde os objetos se formam como préconstruídos. Os enunciados, dessa forma, articulam-se entre si no interior dessa rede, estabelecendo a referência dos elementos do saber dessa FD: "Língua dos patriarcas, língua em que estão escritos a Torah na Safá Kedosha” (na língua sagrada).

ER SD2. Saber hebraico significa ter um maior contato com Israel, ao ir para lá me sentia um pouco mais israelense. Entender o que lemos e o que ouvimos em hebraico para mim é muito importante. Saber outras línguas é importante, pois assim ao viajarmos, por exemplo, nos comunicamos sem muitas dificuldades, e para um futuro trabalho uma língua a mais pesa muito na seleção, e para contatar pessoas estrangeiras.

Já para este enunciador da SD2, diferentemente da SD1, o saber a língua hebraica está relacionado ao Estado de Israel - Estado-nação moderno, à cidadania israelense. Cf. citação: "Lá me sentia um pouco mais israelense".

Para este enunciador, na dimensão linear do dizer, no fio do discurso, ou seja, no intradiscurso, o hebraico está relacionado à língua hebraica em sua estreita relação ao atual Estado de Israel, a língua falada pelos israelenses na atualidade. Na teoria lacaniana essa representação corresponde predominantemente ao registro do

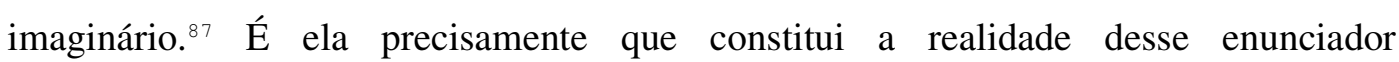
considerando a análise no nível do intradiscurso. Ao tecido do representável, que

\footnotetext{
${ }^{87}$ Milner descreve os três registros que se articulam na produção de sentido estabelecidos pela teoria lacaniana da subjetividade: o real, o simbólico e o imaginário.
} 
constitui a realidade para um sujeito, corresponde o domínio das relações de semelhança e dessemelhança, das propriedades atribuídas a objetos, que são, dessa forma, organizados em classes, localizadas em um espaço e em um tempo. Esse âmbito do registro em que os objetos se ligam é o imaginário (Cf. Serrani, 2001, p. 234).

Por outro lado, este registro está constitutivamente ligado a determinações da ordem do interdiscurso e das identificações simbólicas inconscientes de sua formulação. Ao considerarmos o interdiscurso como um nível interdependente do intradiscurso da análise, ou seja, remetendo o dizer à dimensão vertical, não linear, à rede complexa de formações discursivas em que todo dizer segundo a perspectiva do discurso está inserido, poder-se-ia dizer que para este enunciador o Estado de Israel constitui sua rede de saber preponderante na forma de pré-construído e de um discurso transverso. Cf. menciona: "Saber hebraico significa ter um maior contato com Israel. Ao ir para lá me sentia um pouco mais israelense. Entender o que lemos e o que ouvimos em hebraico para mim é muito importante.

Conforme mencionamos anteriormente, a língua hebraica foi adotada como língua nacional e oficial após a independência do Estado de Israel em 1948. Durante o exílio, por cerca de 1700 anos, a língua hebraica sagrada serviu principalmente como língua de orações e de produção literário-cultural. O renascimento da língua hebraica e sua transformação em língua moderna e nacional, língua em uso, devem-se principalmente aos intelectuais judeus que participaram da Ilustração Judaica (Haskalá) e pela determinação do movimento sionista realizador em falar hebraico em todas as situações em favor de seu projeto nacional. A partir de então a língua hebraica foi laicizada e passou a ser usada como língua "cultural secular", falada e escrita em Israel em todas as áreas do conhecimento.

Entendemos que esta filiação identitária, diferentemente da anterior, perpassa pela historicidade do povo judeu, pautada em rupturas e descontinuidades e que culminou com a adoção da língua hebraica enquanto língua nacional do atual Estado de Israel. Quanto a sua relação com as demais línguas fica claro também que, diferentemente da Sd1, as línguas estrangeiras são representadas como necessárias para fins de comunicação, "como em viagens", ou ainda importantes para se adquirir posição de trabalho numa eventual seleção. 


\section{Escola Secular Laica}

\section{Saber hebraico significa o que para você? E saber outras línguas estrangeiras?}

EL SD1. Saber hebraico significa me identificar e conhecer melhor a minha própria cultura. Significa um elo que une judeus no mundo todo. Outras línguas estrangeiras também significam aprender diferentes culturas, mas meu foco é a questão profissional.

Em sua formulação este enunciador inscreve a cultura como determinante em seu dizer. A "cultura" é aqui representada como um elemento uno, homogêneo, completo e transparente: "Elo que une os judeus de todo o mundo". Esse efeito de sentido que ecoa nessa sequência discursiva é o próprio elemento constitutivo da prática discursiva, que torna necessariamente seu discurso coerente e homogêneo. Ilusão necessária, conforme foi dito anteriormente, parte do imaginário que nos garante uma unidade nos processos identitários. Esta determinação sócio-histórica de uma língua hebraica homogênea e uma cultura única tecida pela memória discursiva contraditória, no interdiscurso, apaga as diferenças da língua e da cultura enquanto tais e permanece inacessível para o enunciador.

Aqui entendemos que se trata do papel estruturante do discurso do outro. $A$ alteridade é aquilo que escapa a atribuição, aquilo que não pode ser definido totalmente. É o sentido que foge, que excede, aquilo que não pode ser dominado. A alteridade é o que forma o sentido do impossível... (ROBIN, 2003, p. 47).

Parece-nos aqui apropriada a definição de Regine Robin sobre a alteridade e o comentário de Sherry Simon polemizando com Tzvetan Todorov sobre a configuração homogênea das identidades e das culturas no colóquio "Fictions de l'identitaire au Québec”. “A identidade cultural não é jamais um dado" (apud Robin, 2003, p. 13).

Para este enunciador o aprendizado de outras línguas estrangeiras está intimamente relacionado ao seu interesse profissional. Cf. segue: "meu foco é a questão profissional".

EL SD2. Saber o hebraico, mais do que qualquer outra língua, significa uma proximidade com as minhas raízes históricas. Entendo que inglês é fundamental devido à rapidez que a comunicação atingiu hoje em dia. Se você não fala inglês, corre o risco de ficar à margem do mundo. Mais no sentido profissional. Espanhol também entendo que é muito importante, apesar de o Mercosul ir de mal a pior.

Como se pode observar, mais do que qualquer outra língua, diferentemente da Sd1 a língua hebraica configura-se para este enunciador como elemento formador da 
unidade do povo judeu pautado em suas raízes históricas. Pêcheux e Fuchs denominam de processos discursivos aos processos de relações de substituição, paráfrases, sinonímias etc., que funcionam entre elementos linguístico- significantes em uma formação discursiva dada. (PÊCHEUX, 1997-b, p. 161) Acrescenta, entretanto, que todo critério puramente linguístico é insuficiente para caracterizar o processo discursivo inerente a uma formação discursiva uma vez que os sujeitos são interpelados em sujeitos falantes (em sujeitos de seu discurso pelas formações discursivas ideológicas que lhes são correspondentes).

Para este enunciador, diferentemente da SD1 da ER, o conhecimento da língua hebraica o remete às suas raízes históricas, às descontinuidades da língua em seus recuos e avanços pautados na dispersão do povo judeu, no contato com outras línguas culturas que permearam a língua em sua trajetória ao longo dos anos.

O sentido de uma palavra, uma expressão ou uma proposição não tem um sentido que lhe seria próprio vinculado a uma literalidade. O sentido de uma palavra, de uma expressão, de uma proposição, etc., não existe em si próprio, mas, ao contrário, é determinado pelas posições ideológicas que estão em jogo no processo sócio- histórico no qual as palavras, expressões e proposições são produzidas (isto é, reproduzidas) (PÊCHEUX, 1997, p. 160).

É importante aqui ressaltar que a maioria dos livros que constituem o arcabouço da literatura judaica clássica foi redigida em língua hebraica quando o povo hebreu vivia no Oriente na época bíblica e talmúdica. Porém, sujeito a domínios estrangeiros, o povo judeu deixou de utilizar a língua hebraica como língua de comunicação oral permanecendo durante séculos como língua de orações e estudos da Bíblia. Na diáspora em contato com outras línguas-cultura os judeus passaram a falar outras línguas e recriaram a sua especificidade em línguas como o ídiche, ou o judeu-espanhol. O hebraico, como se sabe, passou a ser falado e adotado como língua oficial e nacional com a criação do Estado de Israel em 1948. Para este enunciador, a língua hebraica passa a ser determinante em relação às suas raízes históricas e em sua trajetória singular.

Quanto a sua relação com as demais línguas estrangeiras, este enunciador se aproxima da SD2 da EL. O inglês, língua hegemônica no mundo moderno, garante a inclusão profissional do sujeito no mundo globalizado e o espanhol seria a porta de entrada para se estabelecer uma comunicação efetiva com os países do Mercosul.

EL SD3. Saber ler os caracteres hebraicos significa muito para mim que estou muito interessada na cultura e língua ídiche. Como apaixonada pelo ídiche, língua dos meus avós paternos e maternos da Rússia, Polônia e Lituânia, tenho um pouco de 
"ressentimento" do hebraico, pois sinto que é quase uma imposição para judeus do mundo inteiro. É uma questão complicada, pois a decadência do ídiche tem vários fatores que não têm relação com a oficialização do hebraico como língua de Israel. É um tema que incita uma discussão muito ampla. Não sinto apego pelo hebraico, não tenho muito "afeto" pela língua, apesar de me sentir bastante próxima devido ao ambiente judaico que sempre frequentei. Minha relação com o hebraico está na possibilidade de ler, de me integrar no que se passa em Israel, de não negar algo que é considerado importante para um judeu. Gosto de Israel e tenho um vínculo afetivo com o país, sendo assim é útil saber hebraico também por essa razão de simples comunicação. Creio que o hebraico será essencial para me possibilitar campos de estudo e pesquisa em Israel e para leitura em hebraico. Saber outras línguas estrangeiras é absolutamente importante para mim, acho que realmente abre a cabeça, se ao aprendermos outros idiomas nos conscientizarmos da beleza existente nas diferenças culturais que são inevitáveis e com as quais deveríamos conviver com aceitação. Enxergar a beleza nas diferenças é nos aproximarmos como seres humanos, assumindo que apesar das diferenças, ninguém é melhor nem pior, nem mais ou menos importante no mundo, como diz a minha mãe. Além disso, as línguas portam conteúdos históricos e revelam a humanidade e suas nuances culturais.

A SD3 põe em questão justamente a institucionalização da língua hebraica como língua oficial e nacional em sua relação contraditória à língua ídiche. A ideia de falar hebraico em todas as situações da vida diária em Israel como parte do projeto de hebraização que toma corpo com o renascimento do sentimento nacional judaico, conforme mencionamos anteriormente, não foi instaurada sem divergências e batalhas entre a população judaica em Israel. Os judeus do Leste Europeu falantes do ídiche a queriam como a língua oficial para todo o povo judeu. Em 1913, ocorreu a chamada "guerra das línguas" após um debate sobre qual seria a língua de instrução em Física e Matemática no Technion. A guerra terminou com a vitória do hebraico. (cf. Shavit, 2010, p. 1).

Este enunciador, como apaixonado pelo ídiche, manifesta o seu ressentimento em relação a sua obrigatoriedade de falar o hebraico. Cabe aqui lembrar que as línguas judaicas: O Ídiche na Europa Central e Oriental falado pelo universo dos ashkenazitas, bem como o Ladino, falado pelos sefaraditas, no Império Otomano no século XV, após a expulsão dos judeus da Espanha, passaram a se constituir como elementos culturais fundamentais na preservação da identidade e unidade do povo judeu no exílio, antes constituídas principalmente por valores ético-religiosos ${ }^{88}$. Entretanto, doutrinas de cunho racista transformaram a desigualdade das raças em antissemitismo, que alcançou

${ }^{88}$ Conforme Szuchman, E. Identidade / identificação na condição judaica, 2006, p. 141 (trabalho de Mestrado). 
seu apogeu na Segunda Guerra Mundial, com o Holocausto, onde a maioria dos ashkenazitas falantes do ídiche foi dizimada.

Pensamos que a aprendizagem de línguas perpassa pela relação afetiva que as palavras carregam. As palavras da mãe, a voz, a descoberta das palavras das significações linguísticas são indissociáveis da experiência com o outro. (Cf. Revuz, 2001, p. 219) “Assim, muito tempo antes de poder falar, a criança é falada intensamente pelo seu ambiente, e não há uma palavra que não seja, a um só tempo, designação de um conceito e discurso sobre o valor atribuído a esse conceito pelo ambiente".

Para este enunciador do universo ashkenazita de avós paternos e maternos da Rússia, Polônia e Lituânia, o ídiche representa sua língua de afeto, conforme relata: "Não sinto apego pelo hebraico, não tenho muito "afeto" pela língua apesar de me sentir bastante próxima ao ambiente judaico que sempre frequentei. É uma questão complicada, pois a decadência do ídiche tem vários fatores que não têm relação com a oficialização do hebraico como língua de Israel. É um tema que incita uma discussão muito ampla".

Este enunciador tem uma visão crítica cultural com respeito às demais línguas diferentemente da visão geral aqui apresentada pela maioria dos alunos que representam o inglês como língua hegemônica de oportunidades profissionais e de ascensão social. Em sua representação, as línguas portam conteúdos históricos e revelam a humanidade e suas nuances.

\subsubsection{O encontro-confronto de segunda língua/ língua estrangeira no processo de ensino-aprendizagem. $O$ caso do hebraico.}

Ao tratarmos de alunos da escola judaica consideramos a diversidade e heterogeneidade das línguas trazidas pelos imigrantes judeus, ou seja, sua origem linguístico-cultural e seu desdobramento entre seus filhos e netos. Trata-se do Ídiche, do Hebraico, do Árabe e Ladino enquanto línguas judaicas e das demais como o Alemão, Polonês, Russo ou Francês, para citar apenas algumas línguas por eles faladas nesses países. Esses imigrantes, ao chegarem ao Brasil, necessariamente tiveram que se comunicar imergir na cultura local, sendo que muitos deles lentamente abandonaram suas raízes religiosas e sua língua de identidade cultural (hebraico, ídiche ou ladino) e se aculturaram passando a confrontar sua língua materna com a língua nacional falada no 
Brasil: o português. A este propósito nos parece relevante a seguinte observação de Melman (1992):

Por razões históricas como as invasões, as migrações e a organização política dos Estados, o bilinguismo sempre foi a regra... Existe no mundo por volta de três mil línguas faladas por duzentos Estados politicamente individualizados. Tal distribuição é evidentemente possível graças unicamente a prevalência de um bilinguismo. Este bilinguismo é paradoxal. Do ponto de vista linguístico nada se opõe a penetração de uma língua por outra e a tendência mecânica, espontânea, deveria ser a do apagamento, da assimilação das línguas minoritárias. Por outro lado, o inconsciente não cria nenhum obstáculo à mixagem das línguas. Pode reter em seu seio palavras locuções, fragmentos inteiros de discursos tomados de uma língua da infância que em seguida tornou-se estrangeira. $\mathrm{O}$ inconsciente não é nem nacionalista nem xenófobo. (MELMAN, 1992, p. 16)

Esse processo de integração dos imigrantes judeus à sociedade brasileira, aprendendo a falar o português, adquirindo os mesmos hábitos e costumes, mandando seus filhos às mesmas escolas, participando das mesmas organizações comunitárias, segundo Rattner, H. (1977), contribuiu para a fusão e uniformização da comunidade judaica, inicialmente composta por elementos tão heterogêneos. De fato, quanto mais aberta e tolerante a sociedade adotiva, mais rapidamente se processam as mudanças culturais necessárias a sua integração e novos padrões de comportamento são adquiridos nesse processo, afetando profundamente a personalidade e a identidade cultural dos indivíduos atingidos. Esses imigrantes se mesclaram ao correr dos anos, entretanto, sem perderem suas particularidades de judeus ashkenazim e sefaradim (RATTNER, H., 1977, p. 16).

\footnotetext{
Longe, portanto de ter ocorrido o melting-point ou processo de assimilação, tão temido pelos da primeira geração, os imigrantes, os judeus paulistanos, embora tenham aberto todos os caminhos na vida profissional e social, preferem insistentes, manter sua identidade cultural e religiosa distinta, conservando suas escolas comunitárias, associações juvenis, esportivas e culturais próprias, nas quais a maioria da comunidade está inscrita, frequentando-as e nelas se encontrando, embora muito pouco do conteúdo tradicional e dos valores judaicos nelas sobreviva. (RATTNER, H., 1977, p. 17)
}

Em nossas análises, cabe mencionar que por via de regra, estaremos tratando de alunos falantes do português como língua materna, ou seja, língua em que foram alfabetizados no Brasil, mesmo que não seja, necessariamente, o português a língua materna de um dos pais ou dos avôs enquanto imigrantes que aqui chegaram. Dessa forma, a língua hebraica será aqui tratada como segunda língua / língua estrangeira. Esta complexidade, precisamente, é a que gostaríamos de enfatizar. (cf. Revuz, C., 2001; 
Serrani, 1988; Coracini, M., Grigoletto, M., 2003; Eizerik Marisa, 1994; Melman, C., 1992).

Os imigrantes que chegaram ao Brasil no século $\mathrm{XX}$, em sua maioria, judeus ashkenazitas, fugindo dos pogroms e do antessemitismo da Europa, preservaram nas escolas o ensino da língua de seus antepassados: o hebraico (lingua da Torah e das orações, lingua de prestígio), e o idiche (considerada uma segunda língua dos judeuslíngua do povo). Fatores, entretanto, como o holocausto, o surgimento do Estado de Israel e a maior abertura da sociedade brasileira no período posterior à Segunda Guerra contribuíram de forma decisiva para o enfraquecimento do ídiche no Brasil.

Nos anos 70 e 80, o ídiche no Brasil ficou confinado quase inteiramente a círculos familiares e a grupos ashkenazitas idelologicamente ligados à manutenção de uma identidade judaica expressa na chamada "língua do povo". (GUINSBURG, 1997, p. 4).

Segundo esse autor, somado a esses fatores deve se considerar, sobretudo, que o idiche perdeu sua função aglutinadora (mameloschen - de lingua materna) como instrumento prioritário de comunicação, sem que viesse a ser fortalecido por novas ondas de imigrantes de centros de radiação do universo ashkenaz, quando foram erradicadas as suas raizes mais profundas com a barbárie institucionalizada pelo Estado Alemao: o holocausto.

Ao tratarmos do encontro-confronto entre a língua materna e a estrangeira, gostaríamos de enfatizar que não estamos tratando da língua materna ou estrangeira na acepção simplista conforme considerada na linguística aplicada ou em sala de aula. Por via de regra, a língua materna corresponde à língua falada pela mãe, o que no Brasil corresponderia à língua portuguesa, e a língua estrangeira, a uma segunda ou terceira língua, não falada no nosso contexto do dia a dia. Na prática em verdade se torna difícil distinguir a complexidade envolvida muitas vezes quando se trata de uma ou de outra (Cf. Dabene, 1994). Para nossas considerações o hebraico será aqui referido como segunda língua /língua estrangeira.

Outro aspecto que aqui gostaríamos de considerar é o do "Imaginário Social", conforme trazido pelas pesquisadoras Marisa Eizerik e Nilda Ferreira em seu artigo "Educação e Imaginário Social ${ }^{89 "}$. Questionando os pressupostos positivistas e

\footnotetext{
${ }^{89}$ Referimo-nos ao artigo "Educação e Imaginário Social: revendo a escola". In: Aberto, Brasília, ano 14, n.61, jan/mar.1994. Marisa Eizerik é doutora em Educação e professora da Universidade Federal do Rio
} 
intelectualistas sobre a escola, as autoras colocam em dúvida e desconfiança as verdades absolutas, da ordem da racionalidade científica, os olhares que excluem e reduzem o conhecimento verdadeiro ao pensamento e às ideias claras. Nessa perspectiva reducionista afirmam as autoras que a escola exclui as ideias provenientes dos sentidos e das ideias fictícias, provindas da imaginação. A complexidade, postulam, está presente em qualquer objeto de investigação, e aquilo que é da ordem do real e do ideal, do objetivo e subjetivo são conceitos instituídos socialmente e neles está presente o modo de produção de seus sentidos. Dessa forma propõem um novo olhar sobre os sentidos para a educação e para a escola considerando a dimensão do imaginário social, ou seja, aquilo que produz sentido para o aprendiz. (CASTORIADES, 1982; BACKZO, 1985, apud EIZIRIK e FERREIRA, 1994).

A criança, ao chegar à escola, não abandona o mapa intelectual a que até então recorreu para orientar-se no mundo, para resolver suas questões. Nesse mapa estão presentes referentes de sua identidade: mitos, crenças ideias próprias de seu grupo social, de que ela não pode desfazer-se. Embora não seja um adulto em miniatura, ela carrega consigo uma subjetividade de alguma forma instituída a partir de uma cultura. Nessa criança estão presentes fantasias, desejos, expectativas inclusive em relação à escola. (EIZIRIK, M. e FERREIRA, N., 1994, p. 6)

Partindo do pressuposto de que as relações humanas não resultam estritamente de decisões estritamente racionais, as autoras postulam e reconhecem que o conjunto de normas e valores não paira automaticamente sobre os homens, mas se materializa pelas suas práticas sociais, em seus processos de identificação, em seus arranjos grupais, reforçando ou instituindo elos de sociabilidade entre eles.

É nesse sentido que se pode dizer que o mundo transcende a esfera de natureza em si, porque é vivido real /imaginariamente pelos homens. Ou seja, toda sociedade conta com um sistema de representações cujos sentidos traduzem um sistema de crenças que, em última instância, legitima a ordem social vigente. Trata-se de uma complexa rede de sentidos que circula, cria e recria, instituindo /instituindo-se na luta pela hegemonia. (Ibidem, 1994, p. $6)$.

Vejamos, pois, alguns depoimentos dessa complexa rede de sentidos enquanto fatores não cognitivos inconscientes que perpassam pela aquisição de segunda língua, por nós entendida como um novo espaço potencial para a expressão do sujeito.

Grande do Sul (UFRGS) e Nilda Ferreira é doutora em Educação e professora da Universidade do Rio de Janeiro (UFRJ). 


\section{$\underline{\text { Escola Religiosa }}$}

Conte como foi o curso de língua hebraica em sua escola. Os professores, as aulas e sobre você nesse contexto.

ER SD1. Quando entrei na escola, não sabia praticamente nada em hebraico, pois a escola em que estudava antes, não tinha um bom nível de judaísmo. Logo no primeiro ano, assim como eu, havia outros alunos que vieram de outras escolas e que também quase não sabiam o hebraico, tivemos aulas de reforço com outra professora (que durou somente um ano). Com o passar do tempo, fui aprendendo cada vez mais, até que hoje considero que falo hebraico fluentemente. Talvez não perfeito, mas com muita facilidade. A escola sempre procurou aperfeiçoar mais o seu nível de ensino da língua hebraica, trazendo shlichim (professores) de Israel.

ER SD2. Quando pequena tive muito contato com a língua na escola, quando fui para o colegial comecei a ter menos contato com a língua na escola, pois os professores mudavam muito e nem sempre ensinavam bem. Porém posso dizer que aprendi muito hebraico na escola e tudo o que sei falar foi aprendido lá.

ER SD3. Nunca foram levadas muito a sério as aulas da área hebraica. Mas a escola sempre se esforçou nesse quesito, tentando trazer professores estrangeiros para um melhor ensino, e trazendo provas estrangeiras.

ER SD4. As aulas da área judaica, infelizmente, eram dadas em português, o que diminuiu muito o meu aprendizado da língua. Ainda não falo hebraico fluente, apesar de já ter completado o terceiro colegial na escola e lá estudei desde a pré-escola.

ER SD5. Até a $7^{\mathrm{a}}$ série o hebraico era uma matéria levada a sério e aprendíamos várias coisas. Portanto o ápice de aprendizagem não passa da $8^{a}$ série. Houve uma ilusão que professores israelenses seriam melhores. As aulas não renderam (e não rendem) e não se adquire mais conhecimento do que o básico do básico, na escola não sendo praticado. Foi importante adquirir conhecimento sobre a língua do meu povo e minha religião e aprender o básico do básico, mas foi sempre desvalorizada sua importância se acaso tivesse uma avaliação de Língua Portuguesa no mesmo dia. Até o ensino médio a importância de ivrit e inglês era a mesma. A partir do colegial, comecei a dar mais importância ao inglês por ser matéria do vestibular.

ER SD6. O ensino de hebraico foi bom, mas tendeu a enfraquecer nos últimos anos. O gan (pré-escola) é excelente nessa área e também o primário. Senti que faltou no ginásio e principalmente no colegial. Os professores sempre foram muito bons, mas o desnível de conhecimento entre as alunas tendeu a dificultar o aprendizado.

ER SD7. O curso foi presente desde o início do primário, através de aulas constantes, principalmente com Shlichim, onde se buscou o aperfeiçoamento da língua hebraica, que por alguns foi adquirida, e por outros não.

Iniciarei minha reflexão com o depoimento ER SD7 por considerá-lo bastante representativo sobre o processo de aquisição de uma língua estrangeira. A língua hebraica por alguns foi aprendida, por outros não. Sem fazer um levantamento 
estatístico de quantos alunos adquiriram a língua hebraica em sua passagem pela escola, certamente aí temos uma pista para entender a complexidade da aprendizagem de uma segunda língua.

Conforme este enunciador, a língua hebraica matéria regular do currículo escolar, ministrada com regularidade ao longo dos anos, mesmo com o esforço feito pela escola em trazer professores nativos - shlichim - com o objetivo de aperfeiçoar a aprendizagem da língua, por alguns foi adquirida e por outros não.

Partindo da hipótese que o encontro-confronto com outra língua aparece com uma experiência totalmente nova e sob modalidades variadas trazendo à consciência alguma coisa do laço muito específico que cada sujeito mantém com a "sua" língua, abordaremos as sequências discursivas aqui apresentadas. (cf. Revuz, 2001)

Conforme se pode constatar, as SD1 e SD2 tratam de enunciadores que ao longo da aprendizagem vivenciaram o estranhamento de confronto "necessário" para a aprendizagem de uma língua estrangeira como uma operação salutar de renovação e de relativização da língua materna ou como uma experiência de um espaço de liberdade.

ER SD1. Com o passar do tempo, fui aprendendo cada vez mais, até que hoje considero que falo hebraico fluentemente. Talvez não perfeito, mas com muita facilidade.

ER SD2. Posso dizer que aprendi muito hebraico na escola e tudo o que sei falar foi aprendido lá.

Já os enunciadores da SD3, SD4, SD5 e SD6 põem em questão a complexidade da aprendizagem e de seu funcionamento, representada aqui pelos alunos conforme segue:

ER SD3. Nunca foram levadas muito a sério as aulas da área hebraica.

ER SD4. Ainda não falo hebraico fluente, apesar de já ter completado o terceiro colegial na escola e lá estudei desde a pré-escola.

ER SD5 Houve uma ilusão que professores israelenses seriam melhores. As aulas não renderam (e não rendem) e não se adquire mais conhecimento do que o básico do básico, na escola não sendo praticado.

ER SD6. $\underline{\text { O desnível de conhecimento entre as alunas tendeu a dificultar o }}$ aprendizado. 
Essas dificuldades, ansiedades e questionamentos vividos pelos alunos apontam o quanto é inevitável o "encontro-confronto" entre a chamada língua materna e o aprendizado de uma língua estrangeira. A língua estrangeira provoca desde o primeiro momento uma surpresa e estranhamento por recortar o real de forma diferente da chamada língua materna. A título de exemplo aqui trago algumas expressões que podem nos exemplificar este estranhamento.

Ao tratarmos do possessivo em língua hebraica, diremos:

1. Eu tenho um carro grande (יש לי מכונית גדולה). Ou na negativa:

2. Eu não tenho um carro (אין לי מכונית גדולה).

Traduzindo literalmente a primeira sentença, diremos em português: "existe para mim um carro grande". Traduzindo literalmente a segunda: "não tem para mim um carro grande". O pronome "eu" da primeira pessoa do singular não aparece nessas expressões. Para se referir à idade de alguém em hebraico menciona-se a expressão:

1. Eu tenho 12 anos - (אני בת 12 שנדה), dito por um sujeito feminino. Traduzindo literalmente, diríamos: "sou filha de 12 anos".

2. Tenho 12 anos - (אני בן 12 שנהת). Sou filho de 12 anos, dito por um sujeito masculino.

Estas formas diferentes de exprimir conceitos em língua hebraica nos exemplificam claramente a dificuldade dos alunos ao enfrentarem o confronto entre as línguas, e o exercício deles exigido na desconstrução da ilusão imaginária sob um ponto de vista único na possível tradução termo a termo da palavra à coisa. Nas palavras de Revuz:

O que se estilhaça ao contato com a língua estrangeira é a ilusão que existe um ponto de vista único sobre as coisas, é a ilusão de uma possível tradução termo a termo... Toda tentativa de aprender outra língua vem perturbar, questionar, aquilo que está inscrito em nós com as palavras dessa primeira língua... Pela intermediação da língua estrangeira se esboça o deslocamento do real e da língua. (REVUZ, 2001, p. 221-223).

De fato a língua não pode ser resumida a códigos, formas diferentes que permitem falar o que se pensa na sua própria língua numa língua diferente tomando-se como parâmetro a primeira língua.

Já nas sequências discursivas SD1, SD3, SD6 e SD7:

ER SD1 A escola sempre procurou aperfeiçoar mais o seu nível de ensino da língua hebraica, trazendo shlichim (professores de Israel). 
ER SD3. Nunca foram levadas muito a sério as aulas da área hebraica. Mas a escola sempre se esforçou nesse quesito, tentando trazer professores estrangeiros para um melhor ensino, e trazendo provas estrangeiras.

ER SD6. O ensino de hebraico foi bom, mas tendeu a enfraquecer nos últimos anos... Os professores sempre foram muito bons, mas o desnível de conhecimento entre as alunas tendeu a dificultar o aprendizado.

ER SD7. O curso foi presente desde o início do primário, através de aulas constantes, principalmente com Shlichim, onde se buscou o aperfeiçoamento da língua hebraica...

Depreende-se da fala desses alunos que a língua é um objeto uno, controlável, e quanto maior for o grau de consciência do aprendiz "bom aluno", e dos professores (principalmente estrangeiros) melhor será a aprendizagem. Passa-se para o aluno a imagem de que aprender uma língua é uma atividade consciente e sem conflitos (cf. SD4). Esses modelos de professor "ideal" e de "bom aluno" constroem, sobretudo, modelos de bom "aprendiz de língua estrangeira", excluindo todos aqueles que não se ajustam aos padrões de aquisição ideal de uma língua, e desconsideram, sobretudo, a história pessoal dos alunos. O professor é legitimado e institucionalmente autorizado a manejar o ensino da língua na crença de que ele é depositário de um saber a ser reproduzido cabendo ao aluno assimilá-lo. O que se desconhece de fato é a fragmentação do sujeito tanto do professor como do aluno, perpassados pelo inconsciente e pelas determinações histórico-sociais do dizer, ou seja, por memórias discursivas contraditórias (cf. Serrani, 2001, p. 245 e Coracini, M., 2003, p. 143).

Não são os professores nativos, cf. mencionado pelo ER SD5: "Houve uma ilusão que professores israelenses seriam melhores. As aulas não renderam (e não rendem) e não se adquire mais conhecimento do que o básico do básico, na escola não sendo praticado". Ou mesmo o desnível entre os alunos na mesma turma, os responsáveis pela dificuldade na aquisição da língua ou no seu uso, cf. mencionado na ER SD6: “Os professores sempre foram muito bons, mas o desnível de conhecimento entre as alunas tendeu a dificultar o aprendizado".

Pensamos que estas estratégias de aprendizagem, adotadas pela escola em sua prática de ensino trazendo professores de fora - Shlichim -, trazendo provas do estrangeiro, adotando a política de inclusão entre os diferentes níveis de alunos, cabendo ao aluno o controle de seu processo de aprendizagem de língua estrangeira conforme mencionados nas SD6 acima decorrem de teorias que se apoiam em um sujeito 
consciente, dono de seu dizer capaz de controlar o seu processo de aprendizagem. Nessa abordagem a primeira língua do aprendiz não é sequer levada em conta, talvez por ser parte constitutiva da sua subjetividade. Nos termos de Revuz (2001):

Esse estar-já-aí da primeira língua é um dado ineludível, mas essa língua é tão onipresente na vida do sujeito, que se tem o sentimento de jamais tê-la aprendido, e o encontro com outra língua aparece efetivamente como uma experiência totalmente nova, A novidade, entretanto, não está no encontro com o fenômeno linguístico como tal, mas na modalidade desse encontro. (REVUZ, C., 2001, p. 215).

Quanto aos professores nativos aqui mencionados na SD1, SD3, SD5, SD7, chamados "Shlichim", parece-nos pertinente a observação do Rajagopalan Kanavillil (2001) quanto à ideia do falante nativo como uma espécie do "bom selvagem" linguístico, que tem norteado alguns conceitos básicos da linguística teórica e das políticas da língua adotadas no ensino-aprendizagem de cursos de língua. (RAJAGOPALAN, 2001, p. 28). Sob essa perspectiva prevalece, na maioria dos casos, a compreensão do professor nativo, não como uma das possíveis leituras que teria respaldado nas ideologias vigentes, mas como a única possível, como se o sentido do texto nele estivesse alojado, enclausurado (RAJAGOPALAN, 1997, p. 55). Essa postura do professor nativo reforça uma noção de "professor ideal", transcendental, o que faz dele um mito, supostamente dono da verdade e isento de qualquer impureza linguística que pudesse contaminá-lo.

\section{Escola Laica}

Conte como foi o curso de língua hebraica em sua escola. Os professores, as aulas e sobre você nesse contexto.

EL SD1. As aulas de hebraico na escola sempre foram encaradas como uma obrigação. Em minha opinião as aulas eram de boa qualidade, mas sem estimular o interesse genuíno da maioria dos alunos.

EL SD2. Sempre fui um aluno bastante aplicado. Frequentava a turma avançada nas aulas de hebraico. O curso era bom. Aprendi o hebraico com razoável facilidade

EL SD4. O curso foi intenso, todos os dias com aulas de hebraico. Músicas, literatura, Tanach, gramática. Eu era da "turma forte"... Mas mesmo assim, chegar a Israel e sair falando hebraico é muito difícil. Fui três vezes para Israel para curtos períodos de tempo, o maior deles foi de dois meses numa espécie de programa de férias da agência judaica juntamente com a escola quando tinha 16 anos. Sempre sou capaz de entender boa parte do que está sendo falado em conversas quando estou em Israel, mas a dificuldade de encontrar as palavras para me expressar é grande. Apesar disso, $\underline{\text { sinto que }}$ o hebraico me é uma língua muito familiar. Gosto muito de idiomas e sei que se eu 
passasse algum tempo me dedicando ao aprimoramento do hebraico, seja estudando, mas principalmente vivendo por alguns meses em Israel, conseguiria ter certa fluência. Sinto que a parte de conversação no meu aprendizado de hebraico foi insuficiente, apesar dos bons professores que tive. Mas creio que a única forma de aprender uma língua com fluência é realmente se impregnando na cultura de um país vivendo por alguns meses e sentindo a entonação e a melodia implícita no idioma. Aconteceu para mim algo parecido, na área de inglês. Fiz Cultura Inglesa por vários anos, tinha certa facilidade. Mas quando fui viver na Inglaterra (onde morei por 4 anos e meio) tive muita dificuldade com o idioma nos primeiros meses. Contrariamente, vivi também na França aonde cheguei sem ter aprendido nada de francês, e fiz um curso lá mesmo. Talvez por ser uma língua latina, ou pelo momento de vida em que estava, aprendi muito rapidamente em pouquíssimos meses e hoje em dia é o idioma estrangeiro que falo melhor.

EL SD7. Tive aula de hebraico só até a $8^{\mathrm{a}}$ série, nunca gostei das aulas e nunca dei importância ao aprendizado da língua.

EL SD9. As professoras sempre tentaram passar o hebraico para gente de uma maneira descontraída e divertida: traziam jogos, músicas, historinhas e faziam de tudo para aproveitarmos o máximo. Sempre tive um grande interesse pela língua, as aulas de hebraico na escola sempre foram muito válidas, cada aula era uma nova palavra aprendida, uma nova música e/ou um novo conhecimento. Comecei a realmente perceber a importância do hebraico quando viajei para Israel e precisei me comunicar com o pessoal de lá, e até mesmo agora que tive que fazer meu currículo, um idioma a mais é sempre um diferencial muitas vezes positivo. Além das vezes que quero fazer comentários em público com amigos e não quero que as pessoas ao redor entendam, a melhor maneira é sempre o hebraico.

EL SD10. O curso foi bom, apesar de os alunos não levarem muito a sério. Tive excelentes professores. Porém, não consigo falar hebraico. Só percebi isso na Marcha da Vida em Israel, e sei que falava bem há alguns anos.

EL SD11. O curso, para ser sincera, foi fraquíssimo, tanto é que não sei falar praticamente nada! As aulas de hebraico na minha época foram sempre aulas com muita desordem, bagunças.

EL SD12. O hebraico foi uma língua que eu aprendi desde que eu entrei na escola até os meus 14 anos. Acredito que até tive bons professores, uma vez que saí de lá, sabendo usar pelo menos até frases no passado (o que no inglês seria o "past simple") pelo que eu lembre. No entanto, eu não acho que eu tenha aproveitado tanto todas essas aulas, já que era uma matéria em que eu me sentia "obrigada" a estudar, o que para um aluno no ensino escolar é algo tido como chato. E comecei a dar mais valor, quando eu estava lá pela sétima, oitava série, que foram os anos que comecei a pensar nas minhas perspectivas de vida, tipo intercâmbio, viajar etc. Infelizmente eu não falo e nem aprendi com o mesmo prazer que eu aprendi inglês, uma língua que em menos tempo eu aprendi mais rápido (mesmo antes de morar fora). Hoje em dia, se perguntarem se falo hebraico, eu digo "eu começo a conversa, mas não sei terminar!" (risos) 
Não diferentemente das sequências anteriormente analisadas, também nas escolas laicas deparamos com aprendizes que adquiriram a língua hebraica com certa facilidade, enquanto outros apresentaram dificuldade e ainda encontramos aqueles que, mesmo tendo passado anos significativos de estudo, não a adquiriram. Depreende-se, entretanto, da fala desses aprendizes que não adquiriram a língua hebraica, uma crítica efeito de sentido - diferente dos aprendizes da escola religiosa, dos quais voltaremos a falar.

Conforme se pode observar acima, enquanto para alguns aprendizes as aulas são representadas descontraídas, lúdicas, interessantes, e até mesmo familiares, para outros as aulas eram uma obrigação, uma coisa chata e desinteressante.

A esse propósito parece-nos interessante a observação de Melman: O inconsciente não é receptor de nenhuma voz; o sujeito deve emprestar-lhe a sua se quiser que o inconsciente se deixe escutar sem que saiba e sem que possa comandá-lo. "A unidade significativa no inconsciente é eminentemente variável” (MELMAN, 1992, p. 49).

Partimos da hipótese que a língua é sempre um objeto complexo e acreditamos que sua prática vai muito além da mera comunicação e da habilidade de expressão uma vez que o contato-confronto com a língua estrangeira questiona de forma determinante a relação que os sujeitos aprendizes mantêm com sua língua e sua história singular, que é sempre social. A modalidade de confronto entre a "língua" do aprendiz e a segunda língua exige uma flexibilidade psíquica constante entre várias dimensões: a afirmação do eu, trabalho do corpo, e dimensão cognitiva.

Conforme depoimentos EL: SD1, SD7, SD12.

EL SD1: As aulas de hebraico na escola sempre foram encaradas como uma obrigação. As aulas eram de boa qualidade, mas sem estimular o interesse genuíno da maioria dos alunos.

EL SD7. Tive aula de hebraico só até a $8^{a}$ série, nunca gostei das aulas e nunca dei importância ao aprendizado da língua.

EL SD12: "Era uma matéria em que eu me sentia obrigada a estudar, o que para um aluno no ensino escolar é algo tido como chato". "Infelizmente eu não falo e nem aprendi com o mesmo prazer que eu aprendi inglês, uma língua que em menos tempo eu aprendi mais rápido (mesmo antes de morar fora)".

Por outro lado, conforme depoimentos EL: SD2, SD4, SD9. 
EL SD2. Sempre fui um aluno bastante aplicado. Frequentava a turma avançada nas aulas de hebraico. O curso era bom. Aprendi a língua hebraica com razoável facilidade.

EL SD4. O curso foi intenso, todos os dias com aulas de hebraico. Músicas, literatura, Tanach, gramática. Eu era da "turma forte" [ ...] sinto que o hebraico me é uma língua muito familiar.

EL SD9. As professoras sempre tentaram passar o hebraico para gente de uma $\underline{\text { maneira descontraída e divertida. Sempre tive um grande interesse pela língua, as aulas }}$ de hebraico na escola sempre foram muito válidas, cada aula era uma nova palavra aprendida, uma nova música e/ou um novo conhecimento.

A complexidade aqui envolvida decorre do fato de que falar é sempre uma prática de expressão que mobiliza simultaneamente tarefas básicas na constituição da subjetividade. Aprender a falar é para a criança estabelecer um compromisso, e encontrar alguma coisa para dizer de seu próprio desejo, alguma coisa dos valores que adquiriram para ela os objetos e as palavras, em uma linguagem tecida a partir do desejo do Outro, enquanto é ela própria modelada a partir desse desejo. (Revuz, 2001, 219). Portanto, falar é sempre uma atividade que envolve significações a partir do desejo do outro e não é raro que este navegar mude de direção (Ibidem, p. 220).

Revuz aponta a nominação (2001, p. 223) como uma operação linguísticodiscursiva que aparece em evidência na aprendizagem de uma língua estrangeira e enfatiza que na língua materna esta operação é sempre simultaneamente uma operação de predicação, uma operação sempre provida de uma carga afetiva. Nos termos de Revuz:

\begin{abstract}
Muito antes de poder falar, a criança é falada intensamente pelo seu ambiente, e não há uma palavra que não seja a um só tempo, designação de um conceito e discurso sobre o valor atribuído a este conceito pelo ambiente. Este sistema de valores impregna completamente o sistema linguístico. Ele diz aquilo que se pode dizer e aquilo que não poderia ser dito; ele manifesta uma relação com a própria língua e o saber que ela permite construir. (Revuz, C., 2001, p.219).
\end{abstract}

Na Análise do Discurso (cf. Pêcheux e C. Fuchs, 1975; Orlandi, 2004) a operação de nominação é entendida como uma operação prenhe de mediações. Nessa perspectiva a tomada da palavra significante, que não tem origem em quem a enuncia, é aquela que excede a ordem da instrumentalidade da língua, e os sentidos aí excedem a ordem da proposição lógica. (Cf. Pêcheux, 2002). No caso particularmente do encontro com segundas línguas, esse encontro faz parte do processo fundamental, mais amplo da tomada da palavra (Cf. Serrani, 2001, p. 247). Quando se toma a palavra, sabemos, 
toma-se um lugar que dirá respeito a relações de poder, mas simultaneamente, toma-se a língua, que tem um real específico, uma ordem própria. Aí a tomada da palavra implica uma posição ideológica e subjetiva e não uma relação de domínio da língua, pautado pelo conhecimento de regras linguísticas ou de sequenciação de situações comunicativas.

Em nossos recortes encontramos que os alunos das escolas laicas, em sua crítica ao processo de ensino-aprendizagem à língua hebraica, assumem um efeito de posiçãosujeito diferente dos alunos da escola religiosa. Apresentam diferentes "domínios de saber" em sua contraidentificação, ainda que também sua posição se realize por um distanciamento, questionamento à identificação - recobrimento à língua hebraica.

Esse domínio de saber, cf. EL: SD1, SD7, SD11, SD12: “As aulas sempre eram encaradas como uma obrigação". "Aulas eram chatas e desinteressantes". "Aulas com muita desordem e bagunça, assumido pelos aprendizes funciona como um princípio de aceitabilidade discursiva em relação a um conjunto de formulações determinando "aquilo que pode e deve ser dito", ao mesmo tempo em que um princípio de exclusão determina "aquilo que não pode ser e não deve ser dito" (COURTINE, 1981, p. 49).

Quanto aos diferentes sistemas de valores atribuídos por esses alunos à língua hebraica em seu processo de ensino-aprendizagem e considerando a formação discursiva didático-pedagógica dos alunos das escolas comunitárias em São Paulo como constitutivamente heterogênea e contraditória, parece-nos operacional, partindo da perspectiva não subjetiva da subjetividade proposta pela Análise do Discurso, analisálos enquanto representações de processos identificatórios que constituem o acontecimento de posições enunciativas significantes em relação à tomada da palavra em segunda língua, tal como proposto por Serrani (1997) em seu artigo "Formações discursivas e processos identificatórios na aquisição de línguas". ${ }^{90}$

Ao analisar o encontro-confronto que inevitavelmente ocorre na aprendizagem de línguas, Serrani (1997) distingue a língua de estrutura "simbólica fundamental" 91

\footnotetext{
${ }^{90}$ Nesse trabalho a autora focaliza o funcionamento de fatores não cognitivos que tem uma incidência significativa no grau de sucesso e forma de acontecimento do processo de aquisição de segunda língua dentro de uma abordagem transdisciplinar, a partir da Linguística Aplicada mobilizando categorias da Análise do Discurso e Psicanálise. Na perspectiva da Análise de Discurso a partir da rejeição de um real da língua estranho à univocidade lógica e tendo como pressuposto a rejeição de toda metalingua universal inscrita de modo inato na mente humana, coloca-se em questão a articulação dual do biológico com o social, incluindo a dimensão simbólica e significante.

${ }^{91}$ Cf. Melman se refere: língua materna é aquela que teceu o inconsciente e não necessariamente aquela falada pela mãe. (Melman, 1992: 44- 45). Língua materna - é aquela na qual funcionou para o pequeno
} 
(que não necessariamente seria a falada pela mãe) da língua estrangeira, enfatizando os jogos implícitos e efeitos de sentido no processo de produção em Segunda Língua. Nas palavras da autora: Esta "estrutura simbólica" cujas marcas formais ganham sentido ao se realizarem processos discursivos, historicamente determinados são as determinantes na constituição do sujeito. (Cf. Serrani, 1997, p. 75).

Nesse processo de aquisição de segunda língua - entendido enquanto inscrição do sujeito na L2, a autora propõe pensar as relações de preponderância nas condensações discursivas uma vez que são as determinantes na constituição do sujeito. Dessa forma entende que as condensações discursivas preponderantes na primeira língua do sujeito do discurso são os materiais através dos quais se estrutura sua relação com o Outro, com a interdiscursividade constitutiva, com o mundo e também consigo enquanto sujeito (sempre clivado) e enquanto ego enunciador que formula sequências intradiscursivas. Em suas palavras:

[...] um dos processos fundamentais que acontece quando o sujeito desenvolve uma "aquisição" bem sucedida de segunda língua (isto é quando acontece o "desarranjo" subjetivo que possibilita um "rearranjo"significante) é a inscrição do sujeito em relações de preponderância na discursividade nova da segunda língua. A relação contraditória do sujeito com ressonâncias discursivas ${ }^{92}$ novas, que a segunda língua introduz possibilita essa alteração na preponderância de suas formações discursivas fundamentais (SERRRANI, 1997, p. 75).

Vejamos, pois:

EL SD2. Sempre fui um aluno bastante aplicado. Frequentava a turma avançada nas aulas de hebraico. O curso era bom. Aprendi a língua hebraica com razoável facilidade.

EL SD4. O curso foi intenso, todos os dias com aulas de hebraico. Músicas, literatura, Tanach, gramática. Eu era da "turma forte"... Mas mesmo assim, chegar a Israel e sair falando hebraico é muito difícil. Fiz Cultura Inglesa por vários anos, tinha certa facilidade. Mas quando fui viver na Inglaterra (onde morei por 4 anos e meio) tive $\underline{\text { muita dificuldade com o idioma nos primeiros meses. }}$ Contrariamente, vivi também na

falante, o interdito de sua mãe. E a chamamos de "língua materna" "porque é inteiramente organizada por este interdito que, de algum modo, imaginariza o impossível próprio de toda língua. [...] $O$ inconsciente funciona como uma língua interditada: o sujeito não pode articular plenamente o desejo que é inerente, que é veiculado por esta cadeia , que é constitutivo desta cadeia”.

92 Serrani opera com a noção de ressonâncias discursivas de significação entendendo que há ressonância de significação quando entre duas ou mais unidades linguísticas específicas (itens lexicais, frases nominais) ou mais modos de dizer (construções indeterminadoras, de tom causal causativistas e assim por diante) encontram-se ligados produzindo um efeito de vibração semântica mútua tendendo a construir a realidade imaginária de um mesmo sentido (cf. Serrani, 1999, p.287). 
França aonde cheguei sem ter aprendido nada de francês, e fiz um curso lá mesmo. Talvez por ser uma língua latina, ou pelo momento de vida em que estava, aprendi muito rapidamente em pouquíssimos meses e hoje em dia é o idioma estrangeiro que falo melhor.

EL SD12. O hebraico foi uma língua que eu aprendi desde que eu entrei na escola até os meus 14 anos. [...] Infelizmente eu não falo e nem aprendi com o mesmo prazer que eu aprendi inglês, uma língua que em menos tempo eu aprendi mais rápido (mesmo antes de morar fora). Hoje em dia, se perguntarem se falo hebraico, eu digo "eu começo a conversa, mas não sei terminar!" (risos)

Como se pode ver, esses alunos estudaram a língua hebraica de forma regular como matéria do currículo escolar durante anos importantes de sua formação. Entretanto, em suas formações discursivas fundadoras constituídas por determinantes ideológicos e subjetivos inconscientes estabeleceram ao longo de sua trajetória relações singulares com a segunda "língua-cultura": o hebraico, o inglês e o francês.

A esse propósito parece-nos interessante a observação de Melman (1992): [ ... ] saber uma língua é muito diferente de conhece-la. Saber uma língua que dizer ser falado por ela, que o que ela fala em você se enuncia por sua boca, como destacado a título de "eu” (Melman, 1992, p. 15).

$\mathrm{Na}$ SD4, o francês foi a língua mais rapidamente adquirida em um período muito curto, e a língua que o enunciador melhor fala atualmente. Na SD12 foi o inglês e já na SD2 o hebraico foi a língua adquirida com facilidade.

Cabe aqui acrescentar que em nossas análises, as questões identitárias em jogo nesse processo de aquisição de segunda língua referem-se à noção de identificação a partir da descoberta do inconsciente (a do descentramento do sujeito), introduzida por Freud, e da concepção heterogênea da linguagem própria à Análise do Discurso. Tratase da imbricação de duas instâncias inconscientes: o eu e o objeto e não de relações intersubjetivas (uma pessoa X se transforma por identificação em Y). Segundo Nasio, com a descoberta do inconsciente (1997, p. 101-102): Foram substituídas as relações intersubjetivas por relações intrapsíquicas ${ }^{93}$. A partir dessas noções introduzidas por

${ }^{93}$ Conforme Nasio, por objeto não deve entender-se a pessoa exterior do outro, ou aquilo em sua pessoa que me é dado perceber conscientemente, mas a representação psíquica inconsciente do outro. A identificação na concepção freudiana é um processo de transformação efetuado no próprio seio do aparelho psíquico, fora de nosso espaço habitual e imperceptivel diretamente por nossos sentidos. (Nasio, 1997, p. 100) 
Freud posteriormente na teoria psicanalítica, Lacan distingue três conceitos de identificação: a simbólica, imaginária e fantasística ${ }^{94}$.

Aqui é preciso insistir que nesse processo de inscrição do sujeito em discursividade da segunda língua, o sujeito é solicitado a afrontar um espaço silencioso no qual é preciso se inventar para dizer eu: aprender uma língua é fazer a experiência de seu próprio estranhamento no mesmo momento em que nos familiarizamos com o estranho da língua e da comunidade que a faz viver (Revuz, 2001, p.229). Essa autora observa que nem todos estão prontos para a experiência do próprio estranhamento. Para alguns esta experiência mobilizará um perigo e assim evitarão aprender a língua. Outros poderão adotá-la como estratégia da pura repetição como o papagaio, ou ainda tentando reduzir a língua a procedimentos lógicos e somente poderão compreender um enunciado em língua estrangeira se cada termo tiver sua correspondência em língua materna.

Conforme se pode observar nas EL: SD1, SD7 e SD10 e SD 11.

EL SD1. As aulas de hebraico na escola sempre foram encaradas como uma obrigação.

EL SD7. Tive aula de hebraico só até a $8^{\mathrm{a}}$ série, nunca gostei das aulas e nunca dei importância ao aprendizado da língua.

EL SD10.. Tive excelentes professores. Porém, não consigo falar hebraico. Só percebi isso na Marcha da Vida em Israel, e sei que falava bem há alguns anos.

EL SD11. O curso, para ser sincera, foi fraquíssimo, tanto é que não sei falar praticamente nada.

Com a noção freudiana do inconsciente que presume uma alteridade simbólica, o mesmo torna-se parte integrante do descentramento do sujeito. Para Freud o adjetivo alemão heimlich (familiar) já contém em si uma inquietude: o secreto, o íntimo, o escondido, o dissimulado (o estranhamente familiar) em oposição ao adjetivo unheimlich. A partir de então o estrangeiro não é nem uma raça nem uma nação. $O$ estrangeiro não é magnificado como Volksgeist secreto, nem banido como perturbador da urbanidade racionalista. Inquietante, o estranho está em nós: somos nós-próprios estrangeiros - somos divididos. (KRISTEVA, 1994, p. 190). Aqui passa-se a admitir o

\footnotetext{
94 Aqui nos referimos ao conceito de identificação de Lacan que o designa "o nascimento de um lugar novo", a emergência de uma nova instância psíquica que introduz a dimensão simbólica que dá origem ao sujeito do inconsciente.
} 
estranho como parte integral de nós-mesmos, a estranheza que habita em nós. E quando fugimos ou combatemos o estrangeiro, lutamos contra o nosso inconsciente - esse “impróprio" de nosso "próprio" impossível. (Ibidem, 1994, p. 201)

\title{
5.4. Terceira Seção: Diretores de escola
}

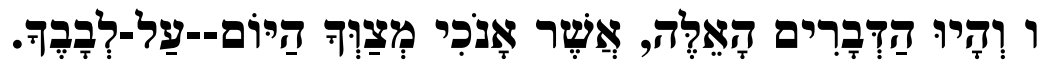

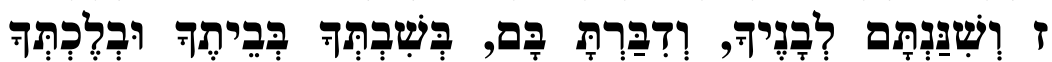

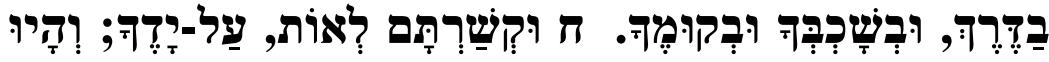

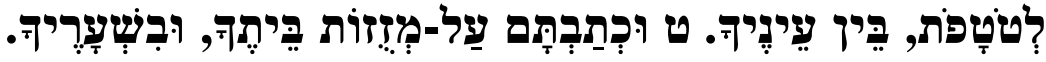

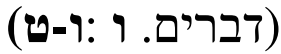

\begin{abstract}
E estas palavras que eu te ordeno hoje estarão sobre o teu coração, e as inculcarás a teus filhos, e delas falarás sentado em tua casa e andando pelo caminho, ao deitar- te e ao levantar-te. E as atarás como sinal na tua mão, e serão por filactérios [Tefilin] entre os teus olhos, e as escreveras nos umbrais [Mezuzá] de tua casa e nas tuas portas. (Deuteronômio. 6: 5-9)
\end{abstract}

\subsubsection{O estatuto da língua hebraica no processo de ensino-aprendizagem: um olhar sobre posições de sujeito: homogeneidade e heterogeneidade.}

As sequências discursivas que aqui serão analisadas correspondem às respostas obtidas através do nosso questionário à pergunta conforme segue:

Como se reflete na prática escolar o papel que é atribuído à língua hebraica na sua escola?

- Quanto aos professores (qualificação);

- Quanto à carga horária dessa disciplina;

- Capacitação de professores em seminários e cursos (periodização);

- Quanto à coordenação. 
Nessa seção sobre o estatuto da língua hebraica nas escolas judaicas comunitárias buscamos sequências discursivas passíveis de observação e de análise, tendo em vista suas interseções com acontecimentos históricos que se discursivizam na linguagem. Essas sequências visam a abordar as diferentes formas de subjetivação, ou seja, modos de identificação, de posições-sujeito: religiosos e não religiosos (laicos/ seculares) à forma-sujeito dominante na condição judaica no confronto, aliança ou transformação que as instituem em sua relação com a cultura, costumes, religião, língua e memória. Em síntese, interessa-nos explorar a heterogeneidade da FD judaica didático-pedagógica.

Para tanto, retomaremos alguns conceitos antes de partirmos para nossas análises. Conforme já mencionamos, em $\mathrm{AD}$ não é vigente a noção psicológica de sujeito empiricamente coincidente consigo mesmo. Ele é sujeito à língua e à história, conforme Orlandi (2002).

Ele é sujeito à língua e à história, pois para se constituir, para (se) produzir sentidos ele é afetado por elas. Ele é assim determinado, pois se não sofrer os efeitos do simbólico, ou seja, se ele não se submeter à língua e à história, ele não se constitui, ele não fala, ele não produz sentidos. (ORLANDI, 2002, p. 49)

Entendemos que essa relação é essencial na produção de sentidos. O sujeito da $\mathrm{AD}$ articula entre si inconsciente e ideologia, ou seja, a ideologia interpela os indivíduos em sujeitos, de tal forma que "os processos de 'imposição/dissimulação' que constituem o sujeito, 'situando-o' (significando para ele o que ele é) e, ao mesmo tempo, dissimulando para ele essa 'situação' (esse assujeitamento) pela ilusão de autonomia constitutiva do sujeito", operam de modo que o sujeito 'funcione por si mesmo' (Pêcheux, 1997-b, p. 133). Vale dizer que a ideologia interpela os indivíduos em sujeitos sem que eles se deem conta de tal interpelação. Ou ainda, dito de outra forma, não há sujeito sem ideologia, embora ela não seja um processo de ordem totalmente consciente.

Trata-se, pois, daquilo que Pêcheux, à semelhança de Althusser, designou de forma-sujeito (PÊCHEUX, 1997-b, p. 183, nota 31). "A forma sujeito, de fato, é a forma de existência histórica de qualquer indivíduo, agente das práticas sociais”. Nesse processo, o recalque inconsciente e o assujeitamento ideológico estão materialmente ligados sem estar confundidos no interior do que se poderia chamar como processo do Significante na interpelação e na identificação, processo pelo qual se realizam as 
condições ideológicas da reprodução /transformação das relações de produção. (ibidem, 1997 b, p. 134).

Quanto às diferentes modalidades de tomada de posição introduzidas por Pêcheux na teoria da AD (cf. Pêcheux, 1997-b, p. 213-231), a interpelação supõe um desdobramento constitutivo de sujeito do discurso, representando um dos termos o "sujeito universal", sujeito da ciência, e o outro o "sujeito da enunciação", o que toma posição com total conhecimento de causa, total responsabilidade, liberdade etc. A relação do sujeito universal com o sujeito da enunciação se dá pela forma-sujeito, podendo representar diferentes modalidades de subjetivação, entre as quais destacamos duas, na medida em que estão diretamente relacionadas com nosso estudo.

A primeira modalidade consiste em um recobrimento entre o "sujeito da enunciação" e o "sujeito universal", de modo que a tomada de posição efetua seu assujeitamento sob a forma de "livremente consentido", o que marca a reduplicação da identificação. A segunda modalidade consiste numa tomada de posição em que o sujeito da enunciação se contrapõe ao sujeito universal. Esta tomada de posição se realiza em oposição à primeira por uma separação (distanciamento, questionamento...) em relação aos saberes que a forma-sujeito comporta (Ibidem, p. 215). Em resumo, o sujeito se contraidentifica com a formação discursiva que lhe é imposta pelo interdiscurso. Para Pêcheux, esta prática é decorrente dos "efeitos paradoxais" introduzidos pelo desdobramento constitutivo da forma-sujeito.

Importante aqui considerar, a propósito da noção de ideologia, o texto de Pêcheux de 1977 "Remontemo-nos de Foucault a Spinoza". Nesse texto Pêcheux afirma: "uma ideologia é não idêntica a si mesma, só existe sob a modalidade da divisão, e não se realiza a não ser na contradição que com ela organiza a unidade de luta dos contrários" (PÊCHEUX, 1980, p. 192). E mais adiante acrescenta: "a esse propósito trata-se de pensar a ideologia sob o prisma da contradição de dois mundos em um só" (Ibidem, p. 195). Diante disso, a formação discursiva na teoria da AD passa a abrigar em seu domínio de saber a diferença e divergência sob o primado da contradição, subtraindo-se dela a homogeneidade e unicidade.

Courtine, retomando essa noção (1982), sustenta que uma FD é uma "unidade dividida" em relação a si mesma, conforme o que segue: “uma FD não é só um discurso para todos, não é também a cada um seu discurso, mas deve ser pensada como dois ou mais discursos em um só” (COURTINE, 1982, p. 245). Segundo ele, é no interdiscurso (enquanto articulação contraditória da FD com as formações ideológicas) que se 
constituem os domínios de saberes próprios das formações discursivas. Daí concluir o autor que o domínio de saber funciona como um princípio de aceitabilidade discursiva em relação a um conjunto de formulações determinando "aquilo que pode e deve ser dito", ao mesmo tempo em que um princípio de exclusão determina "aquilo que não pode ser e não deve ser dito" (COURTINE, 1981, p. 49).

Essas reconsiderações no seio da teoria da $\mathrm{AD}$ levaram a considerar a formasujeito em seus desdobramentos (PÊCHEUX, 1997-b, p. 160), permitindo a instauração da diferença e da desigualdade de saberes no interior da FD. E se a FD é heterogênea, a forma-sujeito que a organiza também é dotada de heterogeneidade, em relação a si mesma, abrigando em seu interior a diferença e a ambiguidade. Isto nos permite pensar as diferentes posições-sujeito que a interpelação ideológica faculta ao sujeito. Como confirma Courtine:

Chamar-se-á domínio da forma-sujeito o domínio de descrição da produção do sujeito como efeito no discurso. Isso conduz a descrever o conjunto de diferentes posições sujeito numa FD como modalidades particulares de identificação do sujeito da enunciação com o sujeito do saber, com os efeitos discursivos específicos que aí estão relacionados. (COURTINE, 1982, p. 252).

Essa forma-sujeito, assim dividida, nos remete a uma noção de sujeito fragmentado entre as diferentes posições-sujeito que sua interpelação ideológica lhe permite. Ao mesmo tempo essa dispersão de posições-sujeito instaura também domínios de saberes heterogêneos e divididos em relação a si mesmo. Vejamos, pois, como essas posições-sujeito são representadas no nosso corpus pelos sujeitos religiosos e não religiosos.

\section{Escola Religiosa}

ER SD5. Primeiramente é importante definir a importância do $\underline{\text { vvrit }}^{95}$ no currículo da escola. Na verdade, o Ivrit é considerado:

a) uma língua sagrada (lashon hakodesh), usada nas rezas e nos estudos da literatura clássica do judaísmo, ou seja, um instrumento de estudo;

b) um fundamento da identidade nacional. "FIM".

Enquanto a primeira faz do Ivrit um "MEIO", na segunda ela é considerada um

Quanto aos professores (qualificação) - De uma forma geral são exigidos formação em pedagogia ou áreas próximas (psicologia, história etc.) e principalmente

\footnotetext{
${ }^{95}$ Literalmente: hebraico na língua hebraica.
} 
formação no exterior, principalmente em Israel, cursos como licenciatura em Tanach, Toshba ${ }^{96}$ ou Rabinato.

Quanta à carga horária dessa disciplina - O Departamento dos Estudos Judaicos detém $45 \%$ da carga total escolar. Isso representa 20 horas-aula por semana. No caso específico do Ivrit são 5 horas-aulas semanais.

Capacitação de professores em seminários e cursos (periodização) - O colégio capacita com consultores vindos de Israel. Atualmente estamos desenvolvendo um projeto que denominamos: Haarachá Chitsonit - avaliação externa. "QUEM ENSINA, NÃO AVALIA". Durante três anos recebemos já 4 visitas que totalizaram 85 horas. No passado fizemos outras e estamos planejando uma específica de $\underline{i v r i t}$ para o próximo ano letivo.

Quanto à coordenação - No caso específico de ivrit possuímos uma coordenação vertical que acompanha o desenvolvimento da língua hebraica desde o ensino infantil até o ensino médio.

Nas SD5 pode-se observar uma posição-sujeito identificada com os saberes da FD judaica didático-pedagógica em que a Bíblia Hebraica (a Torah) e a Tradição Talmúdica representam os princípios organizadores da identidade judaica. A língua hebraica enquanto língua sagrada, "Lashon Hakodesh" (língua usada nas rezas e nos estudos da literatura clássica judaica), é um instrumento para um fim maior, "oㅡ fundamento da identidade nacional judaica".

Para este enunciador o Ivrit - enquanto Lashon Hakodesh - língua sagrada -, conforme mencionado nesse recorte é simbolicamente representado como uma unidade, um bloco homogêneo, valorizado como um dos principais recursos religioso-culturais para a preservação do povo judeu e da Torah. O Lashon Hakodesh é a língua sagrada utilizada na Torah. Com ela D'us criou todo o universo. Cada palavra deste idioma tem um significado intrínseco e não é apenas uma convenção criada pelo homem. A fala é um dos principais fatores que diferenciam o homem do animal e como fator de unificação da humanidade representa também uma das provas da espiritualidade do homem já que ela exprime seu interior. Na Torah encontramos a designação "medaber" - falante - como forma de definição do homem o fato de ele falar. Segundo os conceitos da Torah, a fala possui um poder imenso.

Todas as línguas têm a capacidade de revelar o interior do ser humano, no entanto foi com o Lashon Hakodesh - língua sagrada - utilizada pela Torah que D'us criou o Universo. Adam - Adão, o primeiro homem, e Chava - Eva, a primeira mulher, falavam nesse idioma. As gerações subsequentes também se utilizaram dessa língua,

${ }^{96}$ Toshba - - תורה שבעל פהdo hebraico: Torah Shebeal-pe , ou seja, Lei Oral. 
bem como Noé e seus filhos. Esse idioma foi utilizado até a geração de Peleg, a quinta após Noé. Os homens dessa época decidiram construir a torre de Babel e como castigo de D’us foram dispersos pela terra e passaram a falar várias línguas.

בראשית פרק יא

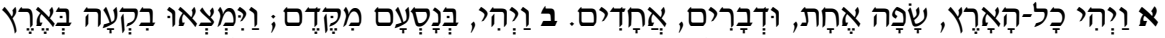

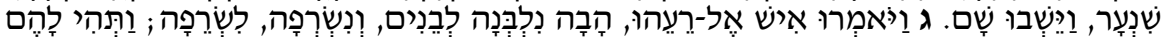

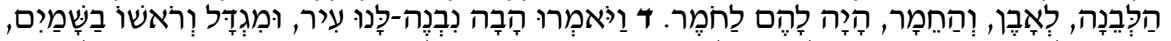

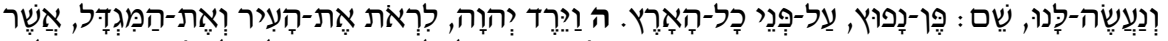

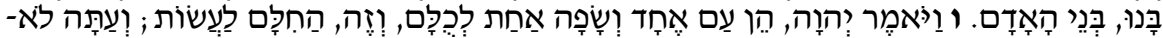

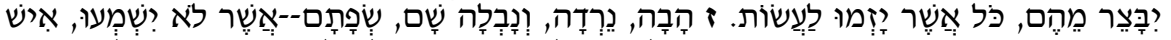

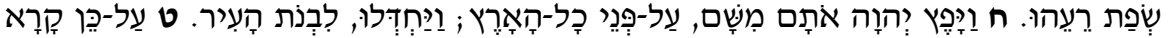

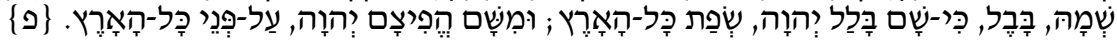

Então tinha uma só língua e mesmas palavras. E foi viajando do Oriente que acharam um vale na terra de Shinar, e ficaram ali. E disse cada homem a seu companheiro: Vinde, façamos tijolos e os cozinhemos no fogo. E foi para eles o tijolo por pedra e o barro foi para eles por argamassa. E disseram: Vinde, edifiquemos para nós uma cidade e uma torre, e que seu cume chegue aos céus, e conseguiremos para nós fama, para que não sejamos espalhados sobre a face de toda a terra. E desceu o Eterno para ver a cidade e a torre que edificavam os filhos dos homens, e disse o Eterno: "Eis um mesmo povo e uma mesma língua para todos eles; foi isto que os fez começar a fazer. E agora, nada os impedira fazer tudo quanto intentarem fazer? Vinde, desçamos e confundamos ali sua língua, para que não entenda cada um a linguagem de seu companheiro". (Gênesis, 11:1-9)

Nessa perspectiva, para este enunciador, a língua hebraica Lashon Hakodesh está relacionada a uma concepção criacionista do homem e do mundo. "A origem da linguagem pelo judaísmo ocorre no primeiro instante da criação do mundo. A frase "E disse Deus", repetida ao longo dos seis primeiros dias do mundo, revela o impacto da linguagem divina sobre o mundo físico, o propósito e a santidade da matéria. Portanto, no momento em que o homem, o único de toda a Criação, expressa seus sentimentos e seus conhecimentos, "estará se assemelhando a Deus, na construção de um mundo melhor com o meio físico, com a sociedade e ainda consigo mesmo" (Cf. Rabino Pinto, Samuel, 2008, p. 57).

Conforme é possível observar, a identidade nacional é aqui mencionada como um fim em si. Um elo entre o passado, o presente e o glorioso futuro promissor que há de advir do grandioso destino messiânico do povo judeu ("nacionalismo religioso") e com ele a língua como uma parte integrante.

Na SD5 encontramos que: "a identidade nacional judaica estaria circunscrita na língua sagrada, consubstanciados na sua tradição escrita e oral. O conhecimento da língua e sua aplicação, fundamentos da religião judaica, estão encerrados na Torah e configuram-se enquanto aplicação de princípios do decálogo, oriundo da revelação 
divina dada a Moisés, e aos seus ancestrais. O Midrash cita que D'us, ao criar este mundo, utilizou a Torah como sua planta e as letras do alfabeto hebraico como agentes criadores. As letras hebraicas do Lashon Hakodesh, a Língua Sagrada, são consideradas como "pedras", enquanto as letras das demais línguas são os "tijolos". "Pedras são criadas por D'us, tijolos são feitos pelos homens".

Em sua relação histórico-discursiva esse enunciador resgata a língua hebraica enquanto Lashon Hakodesh em seu dizer no "já dito" no interdiscurso. É o que se chama em $\mathrm{AD}$ o assujeitamento do sujeito ideológico que consiste que cada um seja conduzido, sem se dar conta, e tendo a impressão de estar exercendo sua livre vontade, a ocupar o seu lugar. (PÊCHEUX e FUCHS, 1975, p. 165-166). Importante aqui destacar que para este enunciador a língua hebraica não tem singularidade fora da Torah.

Conforme mencionamos anteriormente, a relação do sujeito com a ideologia implica um desdobramento constitutivo do sujeito do discurso, de forma que um dos termos representa "o locutor" ou "sujeito da enunciação", o sujeito que toma posiçãosujeito com conhecimento de causa, total liberdade. O outro termo representa "o sujeito universal", que é o sujeito de saber da FD (PÊCHEUX, 1997-b, p. 217). A relação do sujeito da enunciação com o sujeito universal da FD se dá pela forma-sujeito. Os efeitos dos pré-construídos Ivrit - Torah - Lashon Hakodesh - Talmud, as letras do alfabeto hebraico que dominam os sentidos do dizer do sujeito religioso em questão, representam uma superposição entre o sujeito do discurso e o sujeito universal. Tal superposição revela uma identificação plena do sujeito do discurso com a forma-sujeito, a qual marca sua reduplicação da identificação e, por conseguinte, o retorno ao mesmo, de modo que a 'tomada de posição' se realiza sob a forma de 'livremente consentido'. Esta superposição caracteriza o bom sujeito que reflete espontaneamente o "Sujeito" (cf. PÊCHEUX, 1997-b, p. 215).

Importante aqui para nossa análise destacar que as sequências discursivas $\mathrm{Sd} 5$ e seus desdobramentos enunciados pelo locutor religioso alicerçam a identidade judaica enquanto transmissão de língua encerrada na Torah, fundamentada no decálogo e nos 613 mandamentos oriundos da crença na revelação divina a Moisés. Ou seja, a interpelação em sujeito religioso relaciona-se com seu imaginário de Torah e Lashon Hakodesh e sua constituição inconsciente nesse processo simbólico. Para Courtine, esta é uma modalidade particular da identificação do sujeito da enunciação ao sujeito de saber, com os efeitos discursivos que lhe estão ligados. 


\section{Escola Secular/Laica}

Como se reflete na prática escolar o papel que é atribuído à língua hebraica

\section{na escola?}

EL SD6. Primeiramente o curso de hebraico em nossa escola objetiva:

a) Proporcionar ao aluno recursos para desenvolvimento da língua hebraica moderna como meio de comunicação.

b) Habilitar o aluno a ler e escrever para se expressar.

c) Ensinar aos alunos o uso das regras da norma culta.

Quanto aos professores (qualificação) - São todos professores com uma formação de $3^{\circ}$ grau.

Quanto à carga horária dessa disciplina - Mantemos uma carga horária com 3 aulas semanais.

Capacitação de professores em seminários e cursos (periodização) - Nossos professores são anualmente capacitados com cursos cujo objetivo maior é a língua hebraica falada atualmente em Israel.

Quanto à coordenação - idem - uma vez ao ano recebem capacitação.

Diferentemente da SD5 este enunciador-diretor enfatiza o ensino da língua hebraica moderna, refere-se à língua falada e em uso atualmente no Estado de Israel. A "língua sagrada", que durante séculos serviu o povo judeu em suas preces e orações, foi laicizada e passou a ser usada como língua "cultural-secular" antes mesmo de se tornar a língua de uso diário do empreendimento sionista (cf. p. 18 acima). O renascimento da língua hebraica moderna e sua transformação em "low language", isto é, sua penetração em todas as atividades do cotidiano deve-se principalmente a um de seus principais expoentes Eliezer Ben Yehuda, que emigrou para a Palestina em 1881. Para Ben Yehuda o nacionalismo moderno (leumiut) na terra de Israel não sobreviveria sem um idioma próprio, sem a língua de seus antepassados, mas tampouco sobreviveria como entidade nacional definida, sem um idioma próprio, o qual deveria ser empregado não somente nas sinagogas, nas revistas literárias, mas para fins de comunicação cotidiana em todos os assuntos (cf. Ben Yehuda apud, R., 1970, p. 34). Embora a língua sagrada mantenha até os dias de hoje seus rastros no hebraico cotidiano, muitos elementos foram esquecidos, outros reprimidos e ainda outros transformados ${ }^{97}$.

\footnotetext{
${ }^{97}$ Referimo - nos aos depoimento de escritores em Israel como Haim Gouri, Michal Guvrin, Etgar Keret e Orly Castel Bloom, entre outros, colhidos por Nurit Aviv a respeito de sua relação com a língua sagrada. ${ }^{97}$ (cf. Nurit Aviv, em Langue Sacrée, Langue Parlée).
} 
Retomando as palavras de Pêcheux, temos: "a interpelação do indivíduo em sujeito de seu discurso se realiza pela identificação (do sujeito) com a formação discursiva que o domina”. (PÊCHEUX, 1997-b, p. 214).

A "tomada de posição" do sujeito se realiza sob a forma de "livremente consentido". A contraidentificação ocorre quando o sujeito da enunciação "se volta" contra o sujeito universal por meio de uma tomada de posição que consiste em uma separação (distanciamento, contestação, questionamento, revolta...) com respeito ao que o "sujeito universal" lhe "dá a pensar", caracterizando assim o mau sujeito. (Pêcheux, 1997, p. 215).

No nosso caso temos um sujeito enunciador identificado com a formação discursiva secular/laica que se distancia da representação da língua enquanto um objeto sagrado: Lashon Hakodesh, designação anterior por nós acima analisada.

Courtine (1981), reiterando a ideia de assujeitamento considerada por Pêcheux crucial para caracterizar o interdiscurso de uma FD, define o interdiscurso como o lugar no qual se constituem os objetos que o sujeito enunciador se apropria para fazer deles os objetos de seu discurso. As articulações entre esses objetos (o que dá coerência ao propósito do sujeito) são o que Courtine, conforme Pêcheux (1975) chama de intradiscurso da sequência discursiva.

É, portanto, na relação entre o interdiscurso de uma FD e o intradiscurso de uma sequência discursiva produzida por um sujeito enunciador a partir de um lugar inscrito em uma relação de lugares no seio desta FD, que é preciso situar os processos pelos quais o sujeito falante é interpelado-assujeitado em sujeito de seu discurso (COURTINE, 1981, p.35).

Vale ressaltar ainda que, embora este enunciador desloque seu discurso em direção à aprendizagem dos alunos, esta passa a ser vista como um processo controlável, consciente, ideal: “ensinar aos alunos o uso das regras da norma culta”, ensinar a língua hebraica moderna como meio de comunicação.

Para Grigoletto (2008) "conceber a língua como um instrumento de comunicação implica escamotear toda uma gama de funções inerentes à existência das línguas e de relações entre a língua e o sujeito falante" (GRIGOLETTO, 2003, p. 228). A língua é um objeto complexo em vários sentidos, como muito bem relata Revuz (2001); é ao mesmo tempo um objeto de conhecimento intelectual e objeto de uma prática que envolve três dimensões: social, corporal e cognitiva. Para esta autora o que é fundamentalmente solicitado do aprendiz de uma língua estrangeira são as bases mesmas de sua estruturação psíquica através de sua língua materna que, ao mesmo 
tempo, é instrumento e matéria dessa estruturação. A língua nos constitui, ela é "o material fundador de nosso psiquismo e de nossa vida relacional" (REVUZ, op.cit., p. 217).

O enunciador da SD6 acrescenta:

b. Habilitar o aluno a ler e escrever para se expressar.

c. Ensinar aos alunos o uso das regras da norma culta.

Nessa perspectiva o "bom aluno aprendiz de língua estrangeira" é o que domina as regras da norma culta para se expressar. Nesta concepção de linguagem enquanto instrumento de comunicação e de sujeito dotado de razão, capaz de se conscientizar e de controlar o processo ensino-aprendizagem simula-se o mito do nativo e do estrangeiro. Nessa abordagem, normalmente, criam-se situações reais de comunicação entre os nativos da língua a ser aprendida "norma culta" e do estrangeiro evitando o confronto entre língua materna e estrangeira, passando a imagem tanto para o professor como para o aluno de que aprender línguas é uma atividade sem confronto.

Nas palavras de Revuz (2001): A língua estrangeira vai confrontar o aprendiz com outro recorte do real e é precisamente por esta intermediação que se esboça o deslocamento do real da língua provocando um espaço para ressignificações, deslocamentos e rearranjos. (cf. Revuz, 2001, p. 153). Ainda nessa mesma abordagem, segundo Coracini (2003), é preciso compreender que a língua não é um sistema vazio de sentido: "ela traz consigo, a revelia do aprendiz, uma carga ideológica, que o coloca em conflito permanente com a ideologia da língua materna". (cf. Coracini, 2003, p. 153).

Este fato é o que explica a maneira diferente que as línguas explicitam seus tempos verbais, as cores, os fatos, sua cultura. Em hebraico para se dizer: "eu estou com frio", direi: "frio para mim" (קר לי - Quanto aos dias da semana, em hebraico para se referir ao Domingo direi: "hoje é o primeiro dia da semana" (-דיום יום ראשן-). Esse entendimento vem do próprio capítulo da Bíblia hebraica sobre a criação do mundo em que o Sábado é referido como o dia do descanso em relação aos demais seis dias da criação. A designação Shabat - שבת em língua hebraica literalmente significa cessar. (cf. Gênesis, 1:5-31e 2:1-3) 98

\footnotetext{
${ }^{98}$ Referimo-nos ao capítulo 1 que faz referência aos seis dias da criação do mundo e ao capítulo 2: 1 - 3 sobre o dia do descanso designado como o Sábado - שבת -. E assim foram acabados os céus, a terra e todo seu exército, e Deus terminou no $7^{\circ}$ dia toda a obra que fez e cessou de fazê-la no $7^{\circ}$ dia. E Deus, abençoou o sétimo dia e santificou-o, porque nele cessou toda a Sua obra, que Deus criara para fazer (שבת). Os demais dias são os dias de trabalho enquanto a designação Sábado literalmente significa cessar.
} 
Para Coracini (2003), ainda que muitos linguistas acreditem ter observado muitos enunciadores em processo de aprendizagem através de métodos capazes de capturar momentos de processos (como, por exemplo, protocolos verbais e até mesmo diários e entrevistas), "é impossível negar que se procede a uma homogeneização fazendo-se tábula rasa das diferenças, e, sobretudo, da história que cada um inevitavelmente traz consigo, das inúmeras vozes que constituem o seu inconsciente e que, certamente, são responsáveis pelo seu imaginário”. (ibidem, 2003, p. 143). Para Krashen (1982), a aprendizagem se dá de forma consciente, enquanto a aquisição ocorre como um processo inconsciente. Poderíamos dizer, portanto, sob esta perspectiva, que se adquire a língua materna, mas aprende-se a língua estrangeira.

\subsection{Da relação do político com a educação}

Por trabalharmos com diretores de escolas que representam instituições pedagógicas onde a educação é vista em seu sentido mais amplo, achamos importante tecer algumas considerações sobre a educação e a política antes de encerrarmos esta seção.

As escolas judaicas comunitárias inseridas na comunidade maior mantêm uma relação abrangente com a educação como um todo, e em sua prática pedagógica judaica são permeadas por políticas educacionais. Para nós a educação tem um viés político por transmitir de forma sistemática modelos sociais, modelos de comportamento, de trabalho, de vida, de relacionamento com a autoridade, de conduta religiosa etc. É também política porque forma a personalidade dos indivíduos segundo normas que refletem as realidades sócio-políticas e ainda difunde ideias políticas. Como instituição social a escola tem a responsabilidade de educar segundo as normas de uma determinada sociedade, na transmissão de modelos de comportamento, no controle de impulsos agressivos e nos ensinamentos dos deveres de cidadãos.

Para Bernard Charlot (1986): “A neutralidade política da escola só se define, em função de seu próprio postulado, ele próprio, político" (CHARLOT, B., 1986:12). Esse autor entende que da mesma forma como outras formas de totalização do conjunto das

Observe bem que na cultura cristã o dia de Domingo - Dominus - é o dia do Senhor, ou seja, do descanso, enquanto que na cultura judaica Sábado literalmente traduzido por cessar é o dia do descanso semanal. 
experiências vividas tem implicações políticas, a educação, a escola, os programas, $o$ controle pedagógico, etc. são políticos. Para Charlot:

\begin{abstract}
...a escola visa a uma transmissão mais eficaz dos modelos e das normas de comportamento, dos fundamentos éticos do controle pulsional e das ideias sócio-políticas [...] Assim os grupos sociais e as classes sociais procuram fazer da escola o instrumento de suas finalidades, de seus interesses e da difusão de suas ideias. A escola é o campo de lutas que traduzem as tensões e os conflitos que atravessam a sociedade... (CHARLOT, 1986:19).
\end{abstract}

Esse mesmo autor acrescenta que por não ser a sociedade homogênea, uma vez que é formada por grupos diferentes, perseguindo suas finalidades, elaborando modelos particulares de comportamento dependendo do grupo de pertencimento (religioso, cultural, esportivo, político etc.), a escola não pode escapar a esse papel político, pois depende de muitas formas, isto é, quer de um grupo social (igreja, municipalidade, partido político), quer de um poder de Estado, quer de uma associação de pais e de mantenedoras para seu financiamento, sua gestão e seu controle. (Ibidem, 1986).

A título de ilustração do que acabamos de mencionar sobre o papel político educacional que a escola exerce trago duas citações retiradas do marco referencial dessas escolas e de sua missão.

\title{
Missão da Escola Laica
}

Nossos alunos, desde pequenos, vão vivenciando aspectos de sua condição judaica, sua história, suas crenças, suas tradições, sua língua, sua cultura, sua arte, seu folclore. E, mais do que isto, seus valores, através dos quais trarão sua contribuição significativa para a sociedade. Desde pequenos, são envolvidos pela cultura de tzedaká, da justiça social, e sensibilizados para ações e campanhas em prol dos mais necessitados.

\section{Da Cultura e Tradição}

Nossa missão está baseada na transmissão significativa dos valores essenciais de nosso povo e dos momentos chaves de nossa história, fortalecendo a identidade judaico$\underline{\text { sionista do aluno, estimulando a reflexão do espírito crítico, sob a identificação }}$ contínua com o Estado de Israel, educando para uma identidade judaica pluralista e formando cidadãos responsáveis e coerentes de seu papel em sua comunidade e na 
comunidade maior. É nosso objetivo aprofundar os conteúdos da área judaica com ênfase na aquisição da língua hebraica como única língua de nosso povo. Esta aprendizagem é feita entendendo o uso do hebraico como língua viva, produzindo marcos comunicativos para incentivar a fluência dos alunos.

$\underline{\text { O Curso de Torah visa em sua programação, através do estudo dos ensinamentos }}$ e da linguagem da Torah, evidenciar a sua atualidade e fundamentar a ação ética e responsável que dela emana.

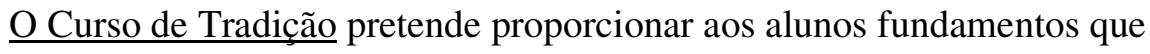
desenvolvam sua identidade e identificação com o judaísmo, pela compreensão e vivência das festas, dos costumes e da liturgia judaica.

\section{Missão da Escola Religiosa}

Uma escola transparente, onde os valores estão sempre presentes.

O Colegio Iavne, desde o início, teve como objetivo proporcionar uma educação religiosa, nos moldes dos ensinamentos da Torah, segundo as normas do Talmud e de seus decodificadores, com o objetivo de formar bons cidadãos e bons judeus.

Também sempre se preocupou com a educação laica, pois acredita que da qualidade do ensino nas duas áreas resulta a excelência na formação de bons cidadãos e bons judeus.

As diretrizes de nossa escola baseiam-se na certeza de que a preservação da identidade judaica só se mantém pela prática da vivência intensa dos valores religiosos.

O Colégio Iavne oferece aulas de hebraico, idioma de gerações e base de toda a cultura clássica do judaísmo, além de estudos destes livros e autores. A questão cultural, as tradições, a preparação para cerimônias fundamentais, tudo isso é valorizado e colocado em prática na escola.

\section{Da Cultura e Tradicão}

O Colégio Iavne se apoia em conceitos considerados essenciais. Eles orientam nosso trabalho e definem a nossa linha de ensino pedagógico e judaico:

- Torah im Derech Eretz - O estudo e a prática da Torah, associados ao estudo $\underline{\text { laico e ao envolvimento com o mundo moderno. Acreditamos que os valores da Torah }}$ aprimoram e fortalecem a condição espiritual e a identidade dos nossos alunos. Junta- 
se a este ponto a responsabilidade de nossa escola de preparar os jovens para o ingresso em boas universidades, dando a eles ferramentas para integrar o mercado global e de excelência e alcançar o sucesso nas carreiras escolhidas;

- Sionismo e comunidade - Nossa escola educa para a identificação $e$ envolvimento com o Estado de Israel, nosso lar nacional judaico. Estimulamos nossos alunos a conhecer e participarem da realidade de Israel. Da mesma forma, buscamos conscientizá-los para que assumam papéis de destaque e responsabilidade nas suas comunidades, liderando e servindo de exemplo. Buscamos sempre sensibilizá-los para serem solidários e participativos, cumprindo ativamente os preceitos de Tzedaká e Chessed.

Ora, nessa perspectiva a educação tem ao mesmo tempo um sentido cultural e sócio-político e não pode ser reduzida ao plano individual descontextualizado do social. A pedagogia e a cultura estão inseridas em realidades sociais e processos ideológicos na teoria da educação. 


\section{6. À GUISA DE CONCLUSÃO}

Este trabalho enquanto um olhar voltado para a função da língua hebraica no processo de ensino-aprendizagem nas escolas comunitárias, secular/laica e religiosa, de São Paulo, no recorte histórico entre os anos de 1980 e 2010, período que compreende a globalização na contemporaneidade, constituiu-se enquanto um gesto de interpretação, na medida em que a ele integramos diferentes atravessamentos da língua hebraica na história judaica.

A trajetória singular da língua hebraica entrecortada por rupturas, descontinuidades e avanços configurou-se como um espaço discursivo heterogêneo em que se determinaram as condições concretas de existência das contradições, através das quais se produziu a história. Essa determinação nos possibilitou um enquadramento da língua hebraica em sua heterogeneidade no processo de ensino-aprendizagem.

A língua hebraica, dada a permanente história de imigração do povo judeu, sujeito a domínios estrangeiros histórico-religiosos e culturais, caracterizou-se juntamente com as tradições ético-religiosas e os costumes como um fator predominante no desafio de preservação da unidade judaica.

$\mathrm{Na}$ antiguidade, o hebraico era o idioma falado pelo povo judeu na terra de Canaã, porém, com o exílio para a Babilônia (586. A.E.C.) o povo judeu passa a falar o aramaico. Os judeus da região da Síria e do Iraque, para preservar sua unidade identitária na Babilônia, continuaram a usar seus antigos textos hebraicos na oração e nos estudos religiosos (RABIN, 1970). No Egito, durante o período helenístico, os judeus passaram a falar e escrever o grego. As relações hegemônicas, entretanto, impostas ao estatuto da língua hebraica no período bíblico excluíram do cânon judaico os livros escritos em grego, designados como apócrifos. (GUINSBURG, 1977).

Este período, designado como bíblico e talmúdico, foi utilizado na composição da maior parte da literatura clássica judaica. Ocupou um lugar de extrema importância nesse trabalho, posto que a Torah (lei escrita) juntamente com o Talmud (lei oral) se constituíram enquanto espaços de materialização do imaginário não só sobre o ensino, mas também sobre os sujeitos envolvidos em nossa pesquisa, predominantemente os da escola religiosa.

A tensão entre identidade e assimilação a outras línguas e doutrinas dominaria a história judaica por muitos séculos. Assimilação ou resistência? O dilema diante do qual 
os judeus se encontravam na Babilônia tornou-se preocupação dominante em relação à manutenção da identidade linguística por toda a sua trajetória. Nessa perspectiva, o exílio, que remete à escravidão no período bíblico, e a diáspora, no período da Mishná, essencialmente determinados por uma dispersão forçada em face de interdições e perseguições religiosas, foram acontecimentos marcantes para o povo judeu em sua singularidade histórica e linguística.

Em decorrência da destruição do Segundo Templo pelos romanos (70 D. E. C) e, sobretudo, do aniquilamento da identidade coletiva judaica: a proibição do estudo da Torah, da observância da lei judaica do Shabat e da circuncisão. O estudo passou a ser considerado a essência da sobrevivência nacional de um povo. Para preservar a unidade coletiva judaica foram fundadas academias em várias regiões da Palestina, entre as quais a academia de Keren Iavne, fundada por iniciativa do Rabi Yochanan Ben Zakai, líder do povo judeu nessa época.

Este acontecimento histórico veio a ser reformulado (enquanto um "já dito" - a memória do dito que possibilita todo dizer) em um novo contexto como a missão principal da escola religiosa Iavne, responsável pela preservação do estudo da Torah e pela perpetuação do judaísmo em nossos dias. Seus fragmentos ressoaram na fala de alunos e professores como observamos em nossas análises: a língua sagrada consubstanciada na Torah.

Durante a Idade Média, desde aproximadamente o ano de 900 até o renascimento da língua hebraica (1880), a comunicação oral efetuava-se normalmente na língua do país onde a pessoa vivia; o modo de falar dos judeus, entretanto, diferenciava-se do de seus vizinhos por incluírem uma mistura de palavras e frases hebraicas e aramaicas retiradas do Talmud, fonte de literatura clássica judaica (Rabin, C., 1970).

Dessa forma, as línguas ídiche e ladino passaram a se constituir como elementos culturais fundamentais na preservação da identidade do povo judeu no exílio, antes constituídas principalmente por valores ético-religiosos. $\mathrm{O}$ ídiche, na Europa do Norte, e o ladino, na Europa Meridional e no Oriente próximo, eram escritos em caracteres hebraicos e permaneceram assim paralelamente. Todo o processo de vida material e espiritual, antes ancorado nas tradições e costumes religiosos, passa a ser permeado pelas línguas.

Os imigrantes que chegaram ao Brasil no século $\mathrm{XX}$, em sua maioria, judeus ashkenazitas, fugindo dos pogroms e do antissemitismo da Europa, preservaram nas 
escolas o ensino da língua de seus antepassados: o hebraico, língua da Torah e das orações, "língua de prestígio"; e o ídiche, considerada uma segunda língua dos judeus, "língua do povo". Fatores, entretanto, como o holocausto, o surgimento do Estado de Israel e a maior abertura da sociedade brasileira no período posterior à Segunda Guerra contribuíram de forma decisiva para o enfraquecimento do ídiche no Brasil.

$\mathrm{Na}$ Alemanha, o antissemitismo moderno, sustentado pelo conceito de superioridade da raça, culminou com o extermínio físico proposto por Hitler: a solução final, eliminando seis milhões de judeus até o final da segunda guerra mundial (1/3 do povo judeu) e impedindo que novas ondas de imigrantes vindas do universo ashkenazita pudessem perpetuar e/ou revitalizar a língua ídiche. Os netos desses imigrantes, muitos deles inseridos em nosso recorte cronológico, nunca chegaram a estudar o ídiche como matéria regular nas escolas, mesmo tendo sido essa a língua falada em suas casas pelos seus avôs ou familiares.

O acontecimento histórico que veio determinar a missão das escolas judaicas como uma unidade no Brasil e no mundo judaico como um todo, indubitavelmente, foi o surgimento do sentimento nacional judaico moderno: o "sionismo", com a consequente criação do Estado de Israel em 1948. O hebraico funcionou como um instrumento educacional de poder único: ajudou a formar a nova sociedade em Israel composta por imigrantes dos mais variados países.

Seu triunfo deve-se em parte porque era o único meio comum igualmente sagrado para todos os imigrantes, e em parte porque era o veículo antigo de uma literatura clássica, nobre, cujos estratos têm influenciado as raízes de todo o pensamento e imaginação europeus. O hebraico se tornou um instrumento para aumentar a dignidade humana, um meio de recriar um grau mínimo de disciplina tanto da emoção como da razão (cf. Berlim, 2005, p. 217).

Dessa forma, na diáspora, a língua hebraica passa a ser ensinada como a principal língua judaica e institucionalizada nas escolas e universidades, ocupando um papel de relevância nos estudos judaicos.

No Brasil, este espaço no entremeio de 1980 a 2010 esteve atravessado por um lado pela escola religiosa, predominantemente apoiada pelo estudo da língua hebraica em seu vínculo ao Estado de Israel pautado na Torah, na Mishna e na Guemará como fundamentos norteadores de sua missão e, por outro lado, composto pelo segmento das escolas seculares/laicas, predominantemente pautadas pela Haskalá (ilustração judaica), 
pelo renascimento nacional judaico e pelo hebraico moderno como língua revitalizada e em uso no atual Estado de Israel.

Nessa perspectiva, a heterogeneidade do imaginário de língua que perpassou o ensino-aprendizagem nas escolas comunitárias judaicas configurou-se em um espaço contraditório em suas modalidades de apropriação/reprodução/transformação de efeitos "pré-construídos" que dominaram os sentidos do dizer de cada grupo de alunos e de professores.

Constatamos que entre os alunos e professores da escola religiosa prevaleceu uma posição-sujeito mais identificada com os saberes em torno da língua hebraica que emanam da religião e da tradição judaica. A língua hebraica foi representada enquanto uma língua sagrada, língua em que foi escrita a Torah, língua ancestral, língua dos patriarcas e por vezes como língua judaica "falada" no atual Estado de Israel. Em seus deslizamentos de subjetivação passaram a integrar em alguns recortes outros domínios de saber: a língua hebraica israelense falada pelos sabras, judeus que nasceram no Estado de Israel (cf. ER SD2).

Já entre os professores e alunos da escola secular/laica encontramos diferentes modalidades de interpelação. Sua relação com a ideologia perpassou diferentes dispersões, interdições e, principalmente, foi pautada pela história e cultura do povo judeu marcado pela Haskalá (ilustração judaica). Cabe enfatizar que o movimento de ilustração judaica causou uma revolução cultural não apenas para os judeus alemães, mas para todo o universo ashkenazita. Fortaleceu a busca pelo direito à liberdade do homem e abriu espaço para o judeu lançar-se na sociedade maior.

Os acontecimentos perpetrados pela Haskalá, pelo sionismo político e pela "revitalização" da língua hebraica vieram a ser ressignificados pelas escolas seculares em sua missão e transmissão dos valores judaicos de forma plural na sociedade maior: pela compreensão, conhecimento e vivência das tradições e da cultura judaica evidenciando na atualidade a sua relação com a língua hebraica "secular moderna" como instrumento de comunicação entre a diáspora e o Estado de Israel. A Torah, o Sidur (livro de orações) e a liturgia das festas passam a ser ensinados em português para uma melhor compreensão dos valores judaicos que deles emanam.

Vale destacar, entretanto, que o antagonismo entre a língua sagrada e a língua secular não se constitui de forma cabal numa dada formação discursiva, pois ele implica necessariamente a contradição. A institucionalização da língua hebraica como matéria regular nas escolas judaicas na diáspora após o holocausto e a criação do Estado de 
Israel, mesmo com o esforço e investimento feito pelas escolas judaicas comunitárias em promover a continuidade da língua hebraica como vetor de identificação coletiva judaica, nem sempre produziu efeitos desejados de conhecimento da língua e de identificação pautados em sua ideologia.

Os saberes no mundo contemporâneo constantemente em mutação implicaram e provocaram o transitório, o efêmero, o descontínuo, ou seja, a instabilidade, no conhecimento que por razões intrínsecas tendeu à superficialidade, à dificuldade e à falta de aprofundamento desestabilizando os pontos de ancoragem necessários para a identificação do sujeito.

No período histórico da globalização no qual nos focamos, cabe mencionar que o ensino do inglês como matéria regular foi paulatinamente incorporado na grade escolar por todas as escolas comunitárias judaicas e atualmente é ministrado desde a pré-escola. A predominante expansão do inglês, instituído atualmente como língua hegemônica no mundo moderno, juntamente com a importância a ele atribuída no mundo judaico atual, e em Israel, ecoou de forma determinante em nossos recortes. A representação imaginária atribuída à língua inglesa perpassou pela ascensão profissional, pela inserção no mercado de trabalho e pela comunicação no mundo moderno conforme constatado em nossos recortes.

Após 1945, encabeçados pelo judaísmo americano, os judeus passaram a experimentar um novo estilo de vida. Nos países democráticos, onde lhes foram concedidos plenos direitos como cidadãos, passaram a assimilar-se cultural e socialmente e, sobretudo, a imprimir uma nova identidade coletiva. Dado o afastamento ocorrido com o enfraquecimento das raízes culturais judaicas entre os imigrantes e o convívio maior entre judeus e não judeus, o hebraico nas escolas judaicas seculares passou a conviver com outras línguas tais como o francês, inglês e espanhol dentro de uma perspectiva comunicativa funcional. (cf. EL. SD4 e SD12).

Em nossos recortes constatamos que as dificuldades na aquisição da língua hebraica permearam tanto as posições enunciativas dos aprendizes da escola religiosa como da secular/laica. Os alunos apresentaram, entretanto, diferentes posições enunciativas que, segundo nosso entendimento, dizem respeito a relações de poder e de seus processos identificatórios.

Nas escolas laicas as críticas foram representadas como "aulas encaradas como obrigação"; "como uma chatice"; "aula de muita bagunça". Apreendemos essas críticas enquanto reflexos das relações de poder aluno-professor atravessados por estratégias 
institucionais que as (re)produzem, instituindo um lugar para o saber. O poder, diferentemente de uma substância, designa relações entre parceiros - um conjunto de ações que se induzem e se respondem umas às outras. [...] O poder só se exerce entre sujeitos livres enquanto livres (cf. Foucault, 1988, p. 240-244). Para o autor, as relações de poder se enraízam profundamente no nexo social; entretanto, por serem permeadas por um saber que se exerce sobre sujeitos livres, há sempre a possibilidade da resistência.

$\mathrm{Na}$ escola religiosa, diferentemente da escola laica, o professor é legitimizado e institucionalmente autorizado pelos aprendizes a manejar o ensino da língua na crença de que ele é o depositário de um saber a ser reproduzido, cabendo ao aluno assimilá-lo, conforme constatamos na seguinte sequência (ER SD6): “[...] os professores sempre foram muito bons, mas o desnível de conhecimento entre os alunos tendeu a dificultar o aprendizado".

Nessa perspectiva, o ensino da língua é passado enquanto um objeto uno, controlável, e, quanto maior for o grau de consciência do aprendiz "bom aluno", melhor será a aprendizagem. O que se desconhece de fato nessa perspectiva de ensino é a fragmentação do sujeito, tanto do aluno como do professor, perpassados pelo inconsciente e por determinações históricas sociais do dizer responsáveis pela identificação.

É preciso lembrar, no entanto, que a identificação não se aprende. Os sujeitos e sentidos resultam de filiações em redes (enquanto formações discursivas) em cujo jogo somos capturados pelo/desde o interior. Somos pegos pelo real da língua e da história sem, todavia, termos acesso ao modo pelo qual a língua nos afeta nessa sua relação com a história (cf. Orlandi, 2001, p. 206).

Ao tratarmos da complexidade do objeto língua e consequentemente do ensinoaprendizagem no encontro-confronto necessário na aprendizagem de segunda língua, enfatizamos a importância de considerar o estranhamento provocado pelo novo recorte do real (ou seja, o da língua hebraica). A língua, em nossa perspectiva, não pode se restringir a códigos, a formas diferentes que permitem falar o que se pensa na própria língua numa língua diferente tomando-se como parâmetro a primeira língua. $\mathrm{O}$ exercício exigido do aprendiz nesse confronto é o da desconstrução imaginária sob um ponto de vista único na possível tradução termo a termo da palavra à coisa. Pela intermediação da língua estrangeira se esboça o deslocamento do real e da língua. (cf. Revuz, 2001, p. 221-223). 
É importante mencionar que a construção das imagens representadas pelos aprendizes não é independente de memórias ou de filiações sócio-históricas de identificação do sujeito, entendidas na AD como interdiscurso. É nessa perspectiva que consideramos a mediação imaginária e simbólica dos alunos aprendizes. Ao falar o sujeito representa o mundo (e se representa) por imagens na cadeia discursiva (SERRANI, 1988, p. 145).

Assim como o sujeito está na língua, também o social, o cultural e o histórico estão nela, atravessados por um imaginário que constrói a sua relação com ela. $\mathrm{O}$ imaginário tem um papel fundamental nos processos de identificação do sujeito e, portanto, no modo singular do sujeito se relacionar com a língua. O imaginário é esse complexo de dizeres que antecedem a identificação do sujeito e que se materializarão pela intervenção do simbólico. Trata-se de uma complexa rede de sentidos que circula, cria e recria, instituindo/instituindo-se na luta pela hegemonia (EIZIRIK, M. e FERREIRA, N., 1994, p. 5). Assim, se na construção desse imaginário negarmos a dimensão histórica e cultural da língua afastando os traços culturais que lhe são constitutivos, reduzindo-a a tão somente instrumento de comunicação, chegaremos talvez, a códigos abstratos, mas não à língua do outro para produzir sentidos a partir dela.

A produção do sentido por sua vez não ocorre no vazio, pressupõe o encontro de um lugar a partir do qual se dá a interpretação; pressupõe uma ancoragem para o dizer, uma cultura, uma história social que constrói, transforma, reformula, ressignifica o modo do sujeito se significar. Para nós trata-se do "espaço necessário" para se fazer novas interpretações, novos pontos de ancoragem, relativizando a língua do aprendiz "sua língua". Nós a entendemos aqui como sua história singular, sua cultura, suas crenças e mitos que perpassam pelo seu imaginário social. Desse modo, reduzir o ensino da língua hebraica a tão somente instrumento de comunicação, segmentando-a e separando-a de seus extratos anteriores permeados pela historicidade, afastando do linguístico os traços culturais que lhe são constitutivos é reduzi-la e esvaziá-la de sua singularidade e especificidade enquanto língua de identificação do povo judeu.

Nos últimos anos, sem almejar a competência linguística na perspectiva instrumental da língua, como a tem pautado a escola laica na "era da globalização", e apreender o ensino enquanto um objeto uno, completo, centrado e racional, desejo que habita o saber pedagógico e o fazer teórico na educação como uma prática pedagógica, a escola religiosa vem sedimentando o ensino-aprendizagem do hebraico em torno de 
uma concepção onde as várias matérias da área judaica (cultura, filosofia e história) são integradas ao ensino da língua.

Sem segmentar e compartimentar a língua secular e a religiosa, a história, a filosofia e a cultura, pensamos que é possível criar novos espaços de identificação, possibilitando aos aprendizes fazer o uso da língua, não somente como instrumento de comunicação, mas, sobretudo, permitindo aos sujeitos elaborarem novas formulações e novos deslocamentos para nela se increverem como autores e não meros reprodutores. Esta concepção tem levado alunos da escola religiosa a atingirem um nível de conhecimento da língua hebraica que lhes proporciona ingressar nos cursos superiores em Israel sem a necessidade de se submeter a cursos preparatórios de hebraico exigidos em instituições acadêmicas.

É também nessa perspectiva que enfatizamos o espaço necessário da interpretação exigido do sujeito para que possa se inscrever numa segunda língua. A partir de um real da língua estranho a univocidade lógica e incluindo a dimensão simbólica e significante, pensamos a cultura, a literatura e a leitura de textos como um lugar privilegiado para a identificação com o outro. O "outro" para o sujeito com o qual se identifica e por meio do qual constrói sua identidade. Ao falar o sujeito representa o mundo (e se representa) por imagens na cadeia discursiva (SERRANI, 1988, p. 145).

Defendemos a idéia, juntamente com Ben Rafael (2007), que a relação privilegiada que adquiriu a língua hebraica no mundo judaico deve ser atribuída, sobretudo, à relação paradoxal que se estabeleceu entre Israel e a atual diáspora.

Há vários anos os judeus em Israel representam uma parte importante do judaísmo mundial. Sob este aspecto, a relação que os judeus da diáspora mantinham com a terra de Israel e com os judeus de Israel não depende mais do sionismo, mas da própria existência do Estado de Israel. Criou-se uma solidariedade coletiva entre a diáspora e Israel, que pode ser definida como "a totalidade do povo judeu". (כלל ישראל). Essa relação paradoxal nos ilustra a definição do Estado de Israel como um "Estado Judeu" e como um "Estado para o povo judeu", ou seja, a concepção que prevalece para muitos na diáspora de que o Estado de Israel é parte integrante do povo judeu (BEN RAFAEL, 2007, p. 21).

É precisamente esta relação que torna a função da língua hebraica na atual realidade judaica na diáspora complexa e multifacetada. Por um lado, o permanente apoio oferecido pelos judeus da diáspora a Israel e suas instituições cria uma dependência com a diáspora. Por outro lado, Israel ocupa um lugar significativo na vida 
judaica da diáspora considerado central na abordagem, no interesse e na ligação da existência coletiva judaica na atualidade. A natureza dessa relação poderia ser definida essencialmente como um círculo em permanente estado de mudanças.

A língua hebraica, dadas essas relações paradoxais de "responsabilidade mútua" que se estabeleceram entre Israel e a diáspora atual, por vezes ecoou em nossos recortes em sua dimensão religiosa, em outras ocasiões em sua dimensão secular e, em outras ainda, se contradisse em sua heterogeneidade. Assim, pensamos que a subjetividade contemporânea se produz como um movimento na história com seus deslocamentos e determinações entre o fora e o dentro, o mesmo e o diferente entre o outro das línguas, espaço de necessárias acomodações na impossibilidade de tudo dizer.

Forjar, entretanto, um ponto final para este trabalho é uma tarefa árdua e difícil não somente pela perspectiva discursiva aqui adotada, ou seja, pela ilusão de que seja tempo de concluí-lo, mas pela própria natureza da pesquisa em língua(gem) e identidade em educação. Não esgotamos todas as questões levantadas sobre as diferentes formas de subjetivação no processo de ensino-aprendizagem, entendendo que este campo se estende também a outras localidades da diáspora onde a língua hebraica é ministrada como língua regular na grade escolar e ocupa um lugar de destaque na área judaica.

Ainda que o conhecimento da língua hebraica no mundo judaico é fraco consideramos que a identidade do sujeito, suas diferentes formas de filiações identitárias ocorrem pela língua e na língua. Abrir mão do ensino-aprendizagem da língua hebraica na diáspora seria se distanciar e apagar as raízes históricas-sociais, culturais e éticas permeadas pela singularidade e peculiaridade do judaísmo como um todo.

Reduzir o ensino da língua hebraica a tão somente instrumento de comunicação, segmentando-a e separando-a de seus extratos anteriores permeados pela historicidade, afastando do linguístico os traços culturais que lhe são constitutivos é reduzi-la e esvaziá-la de sua singularidade e especificidade enquanto língua de identidade do povo judeu.

Pensar o ensino-aprendizagem do hebraico nas escolas judaicas comunitárias como um espaço para fazer reflexões sobre a identificação/identidade, a formação discursiva, o interdiscurso e a memória nos conduziu a penetrar na rede complexa do sujeito, na rede do dizer do outro. "É porque há o outro nas sociedades e na história que pode haver ligação, identificação ou transferência abrindo a possibilidade de interpretar. E é porque há essa ligação que as filiações históricas podem se organizar em memórias, e as relações sociais em redes de significantes" (PÊCHEUX, 2002, p. 54). A identidade 
é um movimento na história, ela se transforma, não é idêntica a si mesma e por esta mesma razão não pode ser considerada como um dado fixo e categórico. Identidade não se aprende, refere-se a posições que se constituem em processos de memória afetados pelo inconsciente e pela ideologia. 


\section{REFERÊNCIAS BIBLIOGRÁFICAS}

A TORAH VIVA. O Pentateuco e as Haftarot por Rabino Aryeh Kaplan, tradução por Adolpho Wasserman. São Paulo: Editora Maayanot.

ACHARD, Pierre. Memória e produção discursiva do sentido. In: ACHARD, P.e al. Papael da Memória. Tradução de J. H. Nunes. Campinas: Pontes, 1999.

AGNON, S.I. La Lengua Sagrada como um Idioma Escrito (p. 17-21). In: Ariel Revista de Artes Y Ciencias de Israel - número 19 - año 1970.

ALEXANDER, Frida. Fillippson. São Paulo: Ed. Fulgor, 1967.

ALTHUSSER, Louis. Aparelhos Ideológicos de Estado. Tradução de Walter José Evangelista e Maria V. de Castro. In: Aparelhos Ideológicos de estado: nota sobre os aparelhos ideológicos de estado. $2^{a}$ edição. Rio de Janeiro: Graal, 1985. Tradução de Posicion.

ANSCOMBRE, G. E.M.: Introduction to Wittgenstein's “Tractus”, Londres: Hutchinson, 1959. Os pensadores Vida e Obra. Investigações Filosóficas. Tradução de Jose Carlos Bruni.

ARENDT H., “La crise de l'éducation” e “Qu'est ce que l'autorité?”. In: La crise de la culture (1954). Paris: Gallimard, 1972. p. 248.

ASLANOV, Cyril. "As políticas das línguas judaicas: entre etnia e nação”. In: Cadernos de Língua e Literatura Hebraica. N. 5, p.73-91. São Paulo. 2006.

AUTHIER-REVUZ, J "Hétérogéneité montrée et hétérogéneité constitutive: élements pour une approche de l'autre dans le discours". In: DRLAV-Revue de linguistique, 1982.

Palavras incertas - As não-coincidências do dizer. Trad. de Claudia Pfeiffer et al. Campinas: Ed da Unicamp, 1998. 
AUSUBEL Nathan. Conhecimento Judaico. Rio de Janeiro: Editora Tradição S.A., 1967. Do original The Book of Jewish Knowledge. (1964).

BACK, Leon, Imigração judaica no Rio Grande do Sul. In: Enciclopédia RioGrandense, vol. IV, Canoas: Ed. Reg. Ltda, 1958.

BAKER, C, Foundations of bilingual education and bilingualism. Clevedon Multilingual Matters, 1993.

BAKHTIN, Mikhail. Marxismo e Filosofia da Linguagem. (Tradução de M.Lahude e Y.F. Vieira). São Paulo: Hucitec, 1979.

Esthétique de la création verbale. Paris: Gallimard, 1984.

- Marxismo e Filosofia da Linguagem. Problemas fundamentais do método sociológico na ciência da linguagem. São Paulo: Hucitec, 2002.

BHABHA, Homi K. O local da cultura. Tradução de Myriam Ávila, Eliana Lourenço de Lima, Gláucia Renati Gonçalves. Belo Horizonte: Ed.UFMG, 1998.

BAUMAN ZIGMUNT. Globalização: as consequências humanas. Tradução de Marcus Penchel. Rio de Janeiro: Jorge Zahar Ed., 1999. . Identidade; entrevista a Benedetto Vecchi. Tradução de Carlos Alberto Medeiros. Rio de Janeiro: Jorge Zahar Ed., 2005.

The Hebrew Language in the Era of Globalization. Orgs. Nava Nevo e Elite Olshtain Jerusalem, Magnes Press, 2007.

BENJAMIN, W. Oeuvres, Paris: Gallimard Folio Essais, 2000, p. 119-120.

BEN-RAFAEL, Eliezer. Identity and Language in Transnational Diasporas: New Horizons for Hebrew in NEVO, Nava; OLSHTAIN, Elite (eds.). The Hebrew 
Language in the Era of Globalization. Jerusalem: The Hebrew University Magnes Press, 2007, p. 15 a 25.

Language, Identity and Social Division: the case of Israel. Oxford: University Press / Clarendon, 1994.

BENVENISTE, E. O homem na língua. In: Problemas de linguística geral (Tradução de M.G.Novak e L. Néri), São Paulo: Comp. Ed. Nacional/ Edusp, 1966.

BERLIN, Isaiah. A força das idéias. São Paulo: Companhia das Letras, 2005 (tradução de Rosaura Eichenberg).

BOUTET, J. A diversidade social do francês. In: VERMES, G.; Boutet, J (ORG) Multilinguism. Campinas, Editora da Unicamp, 1989.

BOURDIEU, Pierre. O poder simbólico. Tradução de Fernando Tomaz. Rio de Janeiro: Bertrand Brasil, 1998.

BÍBLIA HEBRAICA por David Gorodovits e Jairo Fridlin. São Paulo: Editora Sefer, 2006.

CHARLOT, Bernard. A Mistificação Pedagógica. Realidades sociais e processos ideológicos na Teoria da Educação. Rio de Janeiro: Ed. Guanabara, 1986.

CHNAIDERMAN, M. Língua(s) - Linguagem(ns) - Identidade(s) - Movimento(s): uma abordagem psicanalítica. In: SIGNORINI, Ines (ORG). Língua(gem) e Identidade: elementos para uma discussão no campo aplicado. Campinas: FAPESP, 2001.

CORACINI, M.J. - Interpretação, autoria e legitimação do livro didático. In: CORACINI, Maria José (ORG) Identidade e Discurso: (des)construindo subjetividades, Campinas: Editora da Unicamp, 2003. . Língua estrangeira e Língua materna: uma questão de sujeito e identidade. In: CORACINI, Maria José (ORG) Identidade e Discurso: (des)construindo subjetividades, Campinas: Editora da Unicamp, 2003. 
. O jogo discursivo na sala de leitura: língua materna e língua estrangeira.

Campinas, SP: Pontes, 1995.

A celebração do outro. Arquivo, memória e identidade. Campinas:

Mercado das Letras, 2007.

COURTINE, Jean-Jacques. Quelques problèmes théoriques et méthodologiques en

Analyse du Discours: à propos du discours communiste adressé aux chrétiens. Langages, Paris, nº. 62, p. 9-127, Juin, 1981.

. 'Définition d'Orientations Théoriques et Méthodologiques en Analyse de

Discours", in: Philosophiques, v. 9, nº 2. Paris, 1982.

O Chapéu de Clémentis. Observações sobre a memória e o esquecimento

na enunciação do discurso político. In. INDURSKY, Freda.; LEANDRO FERREIRA.

Maria Cristina (Org.) Os múltiplos territórios da Análise do Discurso. Porto Alegre:

Sagra-Luzatto, 1999.

COURTINE, Jean-Jacques et MARANDIN, Jean Marie. Quel object pour l'analise du discours? In: Matérialités discoursives. Colloque de 24, 25 e 26 avril, 1980 Nanterre: Presses Universitaire de Lille 1981.

DABÈNE, L. Repères sociolinguistiques pour l'enseignement des langues. Paris: Hachette FLE, 1994.

DELEUZE, Gilles \& GUATTARI, Félix. KAFKA por uma literatura menor. Trad. de Julio Castãnon Guimarães. Rio de Janeiro: Imago Editora Ltda, 1977. Título original: Kafka pour une littérature mineure. (1975)

DERRIDA, J. O monolinguismo do Outro ou a prótese de Origem. Tradução de Fernanda Bernardo. Porto: Campo das Letras, 2001. . Les Yeux de La Langue, L’Herne. France, Septembre, 2005

DUBNOV, Simon. História Judaica. Versão Portuguesa de Ruth e Henrique Iussim. Buenos Aires: Editora S. Sigal , 1953. 
DUBOIS, Jean. Énonce e Énonciation. In: Langages, $n^{\circ}$. 13, Paris: Librairie Marcel Didier, março de 1969.

DUCROT, O. Esboço de uma teoria polifônica da enunciação. In: $O$ dizer e o dito. Campinas: Pontes, 1997.

EIZIRIK, Marisa \& FERREIRA, Nilda Neves. Educacao e Imaginário Social: revendo a escola. Em Aberto, Brasília, ano 14, n.61, jan/mar.1994.

FALBEL Nachman. Estudos sobre a comunidade judaica no Brasil. São Paulo: Fisesp, 1984.

Comunidade judaica de São Paulo: Diálogos nos Anos 40. Centro Cultural São Paulo de 22 de novembro a 16 de Dezembro de 1990. Arquivo Histórico Judaico Brasileiro.

. Judeus no Brasil. Estudos e Notas, EDUSP. São Paulo: Humanitas, 2008, pp. 335- 367.

A Imigração judaica no Brasil no século XX. Revista de Estudos Judaicos - Ano 1, nº.1, Belo Horizonte: Instituto Histórico Israelita Mineiro, 1998.

. David Jose Perez: uma biografia. Rio de Janeiro: Gramond, 2005.

FERGUSON, C.F. 'Diglossia' in: World 15, 1959, p. 325-340.

FERREIRO, E \& TEBEROSKY. Literacy before Schooling. Exeter. NH: Heinemann, 1982.

FISHLER, Ben-Zion. Estudos judaicos na Diáspora. São Paulo: Editora B`nei B`rith, 1970.

FOUCAUlT, M. A ordem do Discurso. Sao Paulo: Ediçoões Loyola, 1996. Titulo original: L’Ordre du Discours. Gallimard, Paris, 1971.

Arqueologia do Saber. (Tradução L.F. Baeta Neves) Rio de Janeiro: Forense Universitária, 2004. 
FREUD, Sigmund. Obras psicológicas completas de Sigmund Freud. Volume XVII (1917- 1919). Uma neurose infantil e outros trabalhos. Tradução: Eudoro Augusto Macieira de Souza. Rio de Janeiro: Imago Editora. 1969.

GOODMAN, Yetta M. Descoberta das invenções das crianças na língua escrita. In: GOODMAN. (ORG). Como as crianças constrõem a leitura e a escrita. Artes Médicas; Porto Alegre, 1995.

GRIGOLETTO, M. Representação, identidade e aprendizagem de língua estrangeira. In: CORACINI, Maria José (ORG) Identidade e Discurso: (des)construindo subjetividades, Campinas: Editora da Unicamp, 2003. As representações da Lingua estarngeira e a constituição do sujeito aluno de Línguas. II congresso Nacional da Abralin e XIV Instituto Lingíustico. 25- 27 de fevereiro de 1999.

GUIMARÃES, E. Os limites dos sentidos - Um estudo histórico e enunciativo da linguagem. Campinas: Pontes, 2002.

GUINSBURG, J. Guia Histórico da Literatura Hebraica. São Paulo: Editora Perspectiva S.A., 1977.

. Aventuras de uma Língua Errante: ensaios de literatura e teatro Ídiche. São Paulo: Perspectiva, 1996.

. O Ídiche no Brasil. Junho, 1997.

. Uma língua - Passaporte: O Ídiche. Revista Espaço Acadêmico, São Paulo, n. 37, junho de 2004.

HAROCHE, C. "Maneiras de ser, maneiras de sentir do individuo hipermoderno". Agora, Estudos em teoria psicoanalítica, Rio de Janeiro: Ed. Contracapa, vol. VII n ${ }^{\circ}$. 2, Julho /dezembro 2004.

Crise da consciência contemporânea e expansão de um saber - não comulativo (A universidade em questão). Histórias e Perspectivas, Uberlândia (32/33): 13- 37, Jan, jun/jul.dez 2005. 
HARRIS, T.K. Death of a Language; History of Judeo-Spanish. Netwark: University of Delaware Press, 1994.

HENRY, P. A Ferramenta Imperfeita, língua, sujeito e discurso. Tradução de Maria Fausta P. de Castro. Campinas: Unicamp, 1992.

HENRY, P. Os fundamentos teóricos da Analise Automática do Discurso. Tradução de Eni Orlandi. In: GADET, F; HAK, Tony (orgs.). Por uma análise automática do discurso: uma introdução à obra de Michel Pêcheux. $3^{\mathrm{a}}$ ed. Campinas: Unicamp,1997 -a.

HERZL, Theodor. Der Judenstaat: Versuch einer modernen Losung der Judenfrage. Leipsig - Wien: Bretitenstein, 1896.

HYMES, D. Models of interection of language and social life. In. GUMPERZ, J.; HYMES, D. (eds.). Directions in sociolinguistics: the ethnography of speaking. New York: Holt Rinehart\& Winston, 1972.

INDURSKY, Freda. Lula lá: estrutura e acontecimento. Porto Alegre: Organon. vol. 17, $\mathrm{n}^{\mathrm{o}} 35,2003$.

A Fragmentação do Sujeito em Análise do Discurso In: INDURSKY, Freda e CAMPOS, Maria do Carmo (Org). In: Ensaios, Discurso, Memória, Identidade. 15 ed. Porto Alegre; Editora Sagra Luzzato, 2000.

KIRSCHBAUM Saul. Presença Judaica na Idade Média Ibérica: A poesia laica e o idioma hebraico. São Paulo: Targumim, 2008.

KRASHEN, S.D. Principles and practice in second language acquisition. Oxford: Pergamon Press, 1982.

KRISTEVA, J. Estrangeiros para nós mesmos. Traduzido por Maria Carlota Carvalho Gomes. Rio de janeiro: Rocco, 1994. 
KUTSCHER, E. Y. A history of the hebrew language. Jerusalem: Magnes Press, 1982.

LACAN, Jacques. O Seminário. Livro 11. Os quatro conceitos fundamentais da psicanálise. Rio de Janeiro: Zahar Editor Ltda, 1988.

. (1966). Escritos. Trad. de Vera Ribeiro. Rio de Janeiro: Jorge Zahar, 1998.

LÉVINAS. Emmanuel. Difficile Liberté. Paris: Albin Michel. 1963, seconde édition refondue et completée, 1976.

LIPNER, Elias. O tribunal do Santo Ofício da Inquisição de Portugal. São Paulo: Pioneiras, 1966.

MALDIDIER, Denise. A inquietação do Discurso. (Re)ler Michel Pêcheux hoje. Tradução de Eni Orlandi. Campinas: Pontes, 2003. 2004.

MARIANI, Bethania. Polifonia. Sentidos de subjetividade: imprensa e psicanálise. Revista do Programa de pós-graduação em estudos da linguagem. Vol. 12, número 1, 2006, p. 21 a 46.

MEDAN, Meir. La Academia de la Lengua Hebrea. In: Ariel Revista de Artes y Ciências de Israel. Jerusalém, n. 19, 1970, p. 38-45.

MELMAN, Charles. Imigrantes: incidências subjetivas das mudanças de língua e país. Tradução de Rosane Pereira. São Paulo: Escuta 1992.

MEY, Jacob. Etnia, Identidade e Língua. In: SIGNORINI, Inês (ORG). Língua(gem) $\boldsymbol{e}$ Identidade: elementos para uma discussão no campo aplicado. Campinas: Fapesp, 2001.

MILNER, J. C. Os nomes indistintos (1983). Rio de Janeiro: Companhia de Freud, 2006. 
MIREILLE. Hadas-Lebel. L'HEBREU: 3000 ans d'histoire. Paris : Albin Michel, 1992.

MYHILL, John. Language in Jewish Society: Towards a New Understanding. Great Britain: Cromwell Press Ltd, 2004.

NACHBIN, Jacob. Idishe Folkzeitung. Rio de Janeiro, 1928 (Gazeta israelita).

NASIO, J.D. Lições sobre 7 Conceitos Cruciais da Psicanálise. Tradução: Vera Ribeiro. Rio de Janeiro: Jorge Zahar ed., 1997.

Cinco lições sobre a teoria de Jacques Lacan. Tradução: Vera Ribeiro.

Rio de Janeiro, Jorge Zahar Editores, 1993.

ORLANDI, Eni. A Análise de Discurso: algumas observações. D.E.L.T.A, São Paulo, v.2, $n^{\circ} .1,1986$.

Discurso e leitura. São Paulo, Cortez; Editora Unicamp, 1988.

. Terra à vista: discurso de confronto: velho e novo mundo. São Paulo: Cortez; Unicamp, 1990, p. 39-44.

O lugar das sistematicidades lingüísticas na Análise de Discurso. D.E.L.T.A, São Paulo, v. 10, n.2., p. 295- 307, 1994.

. A linguagem e seu funcionamento: as formas do discurso, 4. ed.Campinas: Pontes, 1996.

. Maio de 1968, os silêncios da memória. In: ACHARD, P et al. Papel da Memória. Tradução e introdução de J.H. Nunes. Campinas, Pontes, 1999. Identidade lingüística escolar. In. SIGNORINI, Inês (Org). Lingua(gem)

e Identidade: elementos para uma discussão no campo aplicado. Campinas, SP: Fapesp, 2001, p. 203- 212.

Analise de Discurso: Princípios \& Procedimentos. Campinas, SP: Pontes,4.ed 2002.

As Formas do Silêncio: no movimento dos sentidos. 5.ed. Campinas: Unicamp, 2002- a.

Autoria, leitura e efeitos do trabalho simbólico. Campinas: Pontes, 2004 
PAGUIS, Dan. A linguistic Problem. In: The Hebrew Language in the Era of Globalization. Editors: Nava Nevo \& Elite Olshtain. The Hebew University Magness Press, Jerusalem 2007.

PÊCHEUX, M. Cahiers pour l'analyse. Março - abril 1966, reedição, p. 141- 167. . Análise automática do discurso. Tradução de Eni Orlandi. In: GADET, F; HAK, Tony (orgs.). Por uma análise automática do discurso: uma introdução à obra de Michel Pêcheux. $3^{\text {a }}$ ed. Campinas: Unicamp, 1997-a.

Semântica e Discurso; uma crítica a afirmação do óbvio. Campinas, 1997-b. (Original em francês: Les Vérités de la Palice).

Ler o arquivo hoje. Orlandi, Eni (Org), [et al]. Gestos de leitura; tradução: Betania S.C. Mariani [et al]. Campinas, SP: Editora da Unicamp, 1997-c.

. Sur les contextes épistémologiques de l'analyse du discours. Mots, 9, 1984.

O discurso: estrutura ou acontecimento. Campinas: Pontes, 2002.

. O mecanismo do (des) conhecimento ideológico. In: Altusser: Um mapa da Ideologia. Ed. Presença, 1980.

. Remontémonos de Foucault a Spinoza. In: Maldidier,D. Linquietude de discours . Paris, Cendres, 1990. P. 245- 260

. Sur le contextes épistémologiques de l'analyse du discours. Mots, 9, 1984.

. "Papel da memória”. In: ACHARD, P et al. Papel da Memória. Tradução e introdução de J.H. Nunes. Campinas: Pontes, 1999.

PENNY, R. Dialect Contact and social Networks in Judeo - Spanish. Romance Philology 46/2. 1992, p. 125-140.

PINTO, Samuel, N. A dupla face de Abrahão: O ser humano como ser intelectual e social na filosofia do Maharal. Tese de Doutorado. São Paulo 2008. p. 56-71.

RABIN, Chaim. Investigação sobre a Língua Hebraica. Coletânea de artigos sobre a língua hebraica e sua revitalização. (org) Moshe Bar Asher e Barak Dan. Academia da Língua Hebraica, Mossad Bialik, Jerusalém 1997, p. 359-390. (Original do Hebraico) 
חקרי לשון מאמרים בלשון העברית ובאחיותיה, חיים רבין

. Pequena História da Língua Hebraica. Tradução de Rivka Berezin. Do original: עיקרי תולדות הלשון העיברית São Paulo: Summus Editorial Ltda. 1973.

- "El renacimiento de la Lengua Hebrea" in: Ariel Revista de Artes y Ciências de Israel, Jerusalém, n. 19, 1970, 22- 32.

RAJAGOPALAN, K. O conceito de identidade em linguística: é chegada a hora para uma reconsideração radical? In: SIGNORINI, Inês (ORG). Língua(gem) e Identidade: elementos para uma discussão no campo aplicado. Campinas: FAPESP, 2001.

A ideologia da homogeneização: Reflexões concernentes à questão de heterogeneidade na linguística. In: Letras. Universidade Federal de Santa Maria, centro de Artes e Letras, Curso de Mestrado em Letras - n. 14 (Jan/jun. 1997).

Por uma lingüística crítica. Linguagem, identidade e a questao ética. São Paulo: Parábola Editorial, 2003.

RATTNER, Henrique. Tradição e Mudança. São Paulo, Ática, 1977. Pgs. 15-20.

REVUZ, C. Aprentissage d'une langue étrangère et rélation à la langue maternelle. Mimeo, Univ. Paris VII, 1987.

A língua estrangeira entre o desejo de um outro lugar e o risco do exílio.

In: SIGNORINI, Inês (ORG). Língua (gem) e Identidade: elementos para uma discussão no campo aplicado. Campinas: FAPESP, 2001.

ROBIN, R. História e Linguística. São Paulo: Cultrix, 1997. Título do original: Histoire et Linguistique. Paris: Librairie Armand Colin, 1973.

Le Deuil de l'origine. Une langue en trop, la langue en moins. Saint Denis, presses Universitaires de Vincennes, 2003.

ROTH, Cecil. Pequena História do Povo judeu. São Paulo: Fundação Fritz Pinkuss, 1962. Título do original: Short History of Jewish People.

SERRANI-INFANTE, S. Análise de ressonâncias discursivas em micro-cenas para estudo de identidade linguístico-cultural. Trabalhos em Linguística Aplicada, Campinas, p.79-90, jul-dez, 1994. 
- Formações Discursivas e processos identificatórios na Aquisição de Linguas, DELTA, vol.13, No 1, 1997, p. 63-81.

Identidades e Segundas Línguas: as identificações no discurso. In:

SIGNORINI, Inês (ORG). Língua (gem) e Identidade: elementos para uma discussão no campo aplicado. Campinas: FAPESP, 2001.

. Discurso e aquisição de segundas línguas: proposta Areda de abordagem. In: FREDA INDURSKY e MARIA. C. LEANDRO FERREIRA (ORGS). Os múltiplos territórios da Análise do Discurso. Porto Alegre: Sagra Luzzato, 1999.

Fragmentos. Línguas e Processos discursivos - Teoria e Prática. Florianópolis: Editora DAUFSC, 2003.

Abordagem transdisciplinar da enunciação em segunda língua: A proposta Areda. In: SIGNORINI, Inês e Marilda Cavalcanti (ORGS). Linguística Aplicada e Transdisciplinaridade. Campinas: S.P: Marcado de Letras, 1988.

. Diversidade e Alteridade na enunciação em línguas próximas. In: Letras/

Universidade Federal de Santa Maria, curso de mestrado em Letras $-n^{\circ} 14$, Jan./Jun, 1997.

A linguagem na pesquisa sócio-cultural. Um estudo da repetição na discursividade. Campinas: Editora da Unicamp, 1993

SHAVIT, Zohar. The Hebraization Project. In: XI congress of the European Association for Jewish Studies (EAJS). Ravenna, Italy, July 25-29, 2010.

SIVAN, Reuvén. "Ben Yehuda y el Renacimento de la Lengua Hebrea" in: Ariel Revista de Artes y Ciências de Israel, Jerusalém, nº.19, 1970, p. 33-37.

SZUCHMAN, Esther. Identificação / Identidade na Condição Judaica. Tese de Mestrado, UFRGS, Porto Alegre, 2005.

TODOROV, T. Mikhail Bakhtine: le principe dialogique. Paris: Seuil.

TORAH. A lei de Moisés. Tradução, explicações e comentários de Meir Matzliach Melamed. São Paulo: Editora Sefer, 2001. 
WEINBERG. J. Judeus Turcos e judeus alemães. Cem anos de Amor: a imigração judaica no Rio Grande do Sul. Porto Alegre. Federação Judaica do Rio Grande do Sul.

WEINREICH, M. Story of the Ydish Language. Translated by S. Noble. Chicago: University of Chicago Press, 1980.

ZUCHERMAN, G. Language Contact and Lexical Enrichment in Israeli Hebrew. New York: Macmillan, 2003.

$\underline{\text { www.bialik.com.br }}$

$\underline{\text { www.iavne.com.br }}$

WwW.peretx.com.br

WWW.renascenca.com.br 


\section{ANEXO 1 - Questionário para Professores}

Professores de Língua Hebraica e /ou Cultura judaica.
a) Anos de magistério (...).
b) Sou professor de Língua Hebraica (...). Cultura Judaica (...). Tanach (...)
c) Faixa etária para a qual leciona: Jardim de infância (...)
d) Fundamental I (...) Ensino Fundamental II (...)
e) Ensino Médio (...) Ensino Superior (...)

Cite seu histórico escolar

Nome da Instituição em que estudou

Cite o nome das demais instituições que trabalhaste como professor

1. Qual é a importância que você atribui ao aprendizado do hebraico como matéria regular na formação do seu aluno?

2. Qual a importância no atual contexto histórico de aprender outras línguas para seu aluno? (Inglês, espanhol, francês etc.)

3. Quais são os principais obstáculos ou resistências que você percebe no contexto escolar ao ensinar a língua hebraica como matéria regular no currículo? (da escola e suas como professor)

4. Aponte as dificuldades dos alunos na aprendizagem do hebraico como língua estrangeira? 


\section{ANEXO 2 - Questionário para Ex-Alunos}

Aluno ou ex-aluno do Colégio

Quantos anos você estudou na escola

Mencione o período de 19 a

5. Quando você entrou na escola tinha algum conhecimento ou contato com a Língua hebraica tipo: música, palavras isoladas sobre rituais - Bar-Mitzva, Brit-Mila, orações, cumprimentos típicos ou outro...

6. Sua família pais avós de origem materna ou paterna nasceu no Brasil?

a. Em caso negativo aponte sua origem.

7. Em que medida aprender hebraico foi ou é importante para você?

8. Qual a importância que você atribui ao aprendizado de outras línguas estrangeiras? (Inglês, Espanhol Francês, etc.) Explique.

9. Conte como foi o curso de língua hebraica em sua escola. Os professores, as aulas e sobre você nesse contexto.

10. Saber hebraico significa o que para você? E saber outras línguas estrangeiras?

11. Você gostaria de continuar em contato com a língua hebraica? Como? 


\section{ANEXO 3 - Questionário para Diretores}

1. Que disciplinas da área judaica estão incluídas no ensino-aprendizagem de sua escola como matéria regular? E qual é a relevância delas no atual contexto histórico - social em nossa coletividade.

2. Como se reflete na prática escolar o papel que é atribuído à língua hebraica na escola?
a. Quanto aos professores (qualificação)
b. Quanta a carga horária dessa disciplina
c. Capacitação de professores em seminários e cursos (periodização)
d. Quanto à coordenação.

3. Cite as outras línguas estrangeiras que são oferecidas em sua escola. Justifique 


\section{ANEXO 4 - Respostas Alunos}

\section{A. Aluno}

Quantos anos você estudou na escola: 10

Mencione o período: de $1^{\text {a }}$ série do ensino fundamental a $2^{\mathrm{a}}$ serie do ensino médio (sem contar o $3^{\circ}$ colegial)

1. Quando você entrou na escola tinha algum conhecimento ou contato com a língua hebraica tipo: música, palavras isoladas sobre rituais - Bar - Mitzva, Brit Milá, orações, cumprimentos típicos ou outro...

Sim, pela educação judaica da minha casa, e por ter feito o infantil em outra escola judaica.

2. Sua família, pais avós de origem materna ou paterna nasceram no Brasil? Em que caso negativo aponte sua origem.

Meus avós de origem materna nasceram na Polônia assim como meu avô paterno; já minha avó paterna, nasceu no Brasil, no Rio de Janeiro.

\section{Em que medida aprender hebraico foi ou não importante para você?}

Para mim aprender o hebraico é de extrema importância, uma vez que é a língua da história judaica, e por futuros planos, como de estudar e um dia poder morar em Israel.

4. Qual a importância que você atribui ao aprendizado de outras línguas estrangeiras? (Inglês, Espanhol Francês, etc.) Explique.

Considero-as de extrema importância; mas, para mim, não mais importante do que o hebraico, a língua em que eu sinto certa ligação, e certa obrigação em sabê-la.

\section{Conte como foi o curso de língua hebraica em sua escola. Os professores, as} aulas e sobre você nesse contexto.

Quando entrei na escola, não sabia praticamente nada em hebraico, pois na escola em que estudava antes, não tinha um bom nível de judaísmo. Logo no primeiro ano, assim como eu, tiveram outros alunos que vieram de outras escolas e que também quase não sabiam hebraico, tivemos aulas de reforço com outra professora (que durou somente um 
ano). Com o passar do tempo, fui aprendendo cada vez mais, até que hoje considero que falo hebraico fluentemente. Talvez não perfeito, mas com muita facilidade.

\section{Saber hebraico significa o que para você? E saber outras línguas estrangeiras?}

Saber hebraico me da certa sensação especial, coisa que as outras línguas não me dão. Poder falar a mesma língua que nossos patriarcas falavam; a língua que estão escritos os Sifrei Torah, a Safá kedosha. Lógico que saber outras línguas é de extrema importância. Mas para mim, não tanto quanto o hebraico.

\section{Você gostaria de continuar em contato com a língua hebraica? Como?}

Frequientando lugares que me dêem essa oportunidade, dentro de casa, passando um tempo em Israel (pois nada melhor do que a convivência com a língua, pois faz de um jeito ou de outro, você aprender), e espero como já dito anteriormente, poder um dia fazer algum curso e morar em Israel.

\section{B. Aluno}

Quantos anos você estudou na escola: 10

Mencione o período: do jardim até o ensino médio

1. Quando você entrou na escola tinha algum conhecimento ou contato com a língua hebraica tipo: música, palavras isoladas sobre rituais: Bar-Mitzva, BritMilá, orações, cumprimentos típicos ou outro...

Sim, frequentava a sinagoga regularmente durante o Shabat e festas. Tinha conhecimento sobre as Tefilót. Sabia ler e escrever, mesmo que meu vocabulário não fosse tão grande como hoje.

2. Sua família, pais, avós de origem materna ou paterna, nasceu no Brasil? Em que caso negativo aponte sua origem.

Não. Origem: Síria

\section{Em que medida aprender hebraico foi ou não importante para você?}

Foi muito importante para poder entender as tefilót e em viagens para Israel. 
4. Qual a importância que você atribui ao aprendizado de outras línguas estrangeiras? (Inglês, Espanhol Francês, etc) Explique.

$\mathrm{O}$ aprendizado da língua inglesa também foi forte, e recebeu maior importância.

5. Conte como foi o curso de língua hebraica em sua escola. Os professores, as aulas e sobre você nesse contexto.

O curso foi presente desde o início do primário, através de aulas constantes, principalmente com Shelichim, onde se buscou o aperfeiçoamento da língua hebraica, que por alguns foi adquirida, e por outros não.

6. Saber hebraico significa o que para você? E saber outras línguas estrangeiras?

Maior conhecimento tanto ao saber hebraico, quando ao saber outras línguas.

7. Você gostaria de continuar em contato com a língua hebraica? Como?

Sim, porém não através de aulas após o fim do período escolar, e sim através de Shiurim e viagens.

\section{Aluno}

Quantos anos você estudou na escola: 16 anos

Mencione o período: de 1983 a 1999

1. Quando você entrou na escola tinha algum conhecimento ou contato com a língua hebraica tipo: música, palavras isoladas sobre rituais: Bar-Mitzva, BritMilá, orações, cumprimentos típicos ou outro ...

Não

2. Sua família pais avós de origem materna ou paterna nasceram no Brasil? Em caso negativo aponte sua origem.

Pais brasileiros. Avos europeus (Alemanha, Áustria, Polônia e Lituânia)

3. Em que medida aprender hebraico foi ou não importante para você? Israel, 1996. Por ocasiao do programa Nachat. 
4. Qual a importância que você atribui ao aprendizado de outras línguas estrangeiras? (Inglês, Espanhol Francês, etc) Explique.

Saber o idioma Ingles possibilitou- me transitar por outros países com bastante tranqüilidade

5. Conte como foi o curso de língua hebraica em sua escola. Os professores, as aulas e sobre você nesse contexto.

Sempre fui um aluno bastante aplicado. Frequentava a turma avançada nas aulas de hebraico. $\mathrm{O}$ curso era bom. Lembro que não minha época costumava se comentar que o hebraico do Bialik era melhor que o do Peretz e pior que o do Renascença

\section{Saber hebraico significa o que para você? E saber outras línguas estrangeiras?}

Atualmente, não sei mais falar o hebraico, Quanto ao Ingles pratico pouco.

\section{Você gostaria de continuar em contato com a língua hebraica? Como?}

Não é minha prioridade, mas gostaria. Sua origem e relacao com a cultura

\section{Sequências discursivas retiradas da escola religiosa}

1. Saber hebraico significa o que para você? $E$ saber outras línguas estrangeiras?

ER SD1 Saber hebraico me dá certa sensação especial, coisa que as outras línguas não me dão. Poder falar a mesma língua que nossos patriarcas falavam; a língua em que estão escritos os Sifrei Torah, a Safá kedosha. Lógico que saber outras línguas é de extrema importância, mas para mim, não tanto quanto o hebraico.

ER SD2 Saber hebraico significa ter um maior contato com Israel, ao ir para lá me sentia um pouco mais israelense. Entender o que lemos e o que ouvimos em hebraico para mim é muito importante. Saber outras línguas é importante, pois assim ao viajarmos, por exemplo, nos comunicamos sem muitas dificuldades, e para um futuro trabalho uma língua a mais pesa muito na seleção, e para contatar pessoas estrangeiras.

ER SD3. Hebraico é a língua do meu povo e do meu país, mas ainda acho importante ser poliglota, e saber muitas línguas. 
ER SD4. Saber hebraico significa mais para mim do que o aprendizado de qualquer outra língua, pois é em hebraico que a Torah foi escrita, é em hebraico que muitos livros sobre judaísmo são escritos.

ER SD5. A língua hebraica reforça os meus laços com o povo judeu, e é muito importante para a minha formação como judeu e manter a tradição que possuímos.

ER SD6. Saber hebraico está diretamente ligado ao lado religioso, e será útil para mim independente de eu morar ou não em Israel, é útil em cada acontecimento da minha vida. Já outras línguas são estudadas com o âmbito profissional, de alargar o currículo ou facilitar em viagens e comunicação com estrangeiros, ou seja, o lado social e profissional da vida.

ER SD7. Maior conhecimento tanto ao saber hebraico, quando ao saber outras línguas. EL SD1. Saber hebraico significa me identificar e conhecer melhor a minha própria cultura. Significa um elo que une judeus no mundo todo. Outras línguas estrangeiras também significam aprender diferentes culturas, mas meu foco é a questão profissional.

EL SD2 Saber o hebraico, mais do que qualquer outra língua, significa uma proximidade com as minhas raízes. Entendo que inglês é fundamental devido à rapidez que a $\underline{\text { comunicação atingiu hoje em dia. Se você não fala inglês, corre o risco de ficar à margem do }}$ mundo. Mais no sentido profissional. Espanhol também entendo que é muito importante, apesar de o Mercosul ir de mal a pior. Agora qualquer outra língua, seja francês, alemão ou italiano é bem-vinda, claro, mas é um complemento.

\section{$\underline{\text { Sequências discursivas retiradas das escolas laicas - seculares }}$}

EL SD3. Saber ler os caracteres hebraicos significa muito para mim que estou muito interessada na cultura e língua ídiche. Como apaixonada pelo ídiche, tenho um pouco de "ressentimento" (rsss) do hebraico, pois sinto que é quase uma imposição para judeus do mundo inteiro. É uma questão complicada, pois a decadência do ídiche tem vários fatores que não têm relação com a oficialização do Hebraico como língua de Israel. É um tema que incita uma discussão muito ampla. Não sinto apego pelo hebraico, não tenho muito "afeto" pela língua, apesar de me sentir bastante próxima devido ao ambiente judaico que sempre frequentei. Minha relação com o hebraico está na possibilidade de ler, de me integrar no que passa em Israel, de não negar algo que é considerado importante para um judeu. Gosto de Israel e tenho um vínculo afetivo com o país, sendo assim é útil saber hebraico também por essa razão de simples comunicação.

Saber outras línguas estrangeiras é absolutamente importante para mim, acho que realmente abre a cabeça, se ao aprendermos outros idiomas nos conscientizarmos da beleza 
existente nas diferenças culturais que são inevitáveis e com as quais deveríamos conviver com aceitação. Enxergar a beleza nas diferenças é aproximarmos como seres humanos, assumindo que apesar das diferenças, ninguém é melhor nem pior, nem mais ou menos importante no mundo, como diz a minha mãe. Além disso, as línguas portam conteúdos históricos e revelam a humanidade e suas nuances culturais.

EL SD4. Saber hebraico significa estar conectada com a minha cultura e dominar um âmbito a mais dela, além de simbolizar, de certa forma, meu sionismo. É uma forma de expressar meu sentimento por ser judia. Saber outras línguas significa estar inserida no mundo "globalizado" atual.

EL SD5. Significa uma ligação com o meu povo, minhas raízes, meus pais e minha história. As outras línguas é uma maneira de comunicação e de informação.

EL SD6. Saber qualquer língua para mim significa duas coisas: ter vantagem sobre outras pessoas na hora de procurar por um emprego em determinadas áreas, e ter um acesso diferencial à literatura escrita na língua, podendo ler o que foi escrito sem passar pelas mãos de um tradutor que, querendo ou não, sempre modifica o escrito original. A diferença entre aprender uma ou outra língua vai depender de sua importância para a área de trabalho que está sendo almejada ou para a vontade de cada um em ler textos originais. Hoje, como sou estudante de Letras, acredito que aprender qualquer língua seja importante - quanto mais, melhor - e até lamento ter abandonado o hebraico por completo. Mas com certeza saber falar inglês, espanhol, francês é muito mais importante, em geral, do que hebraico, porque são línguas mais conhecidas pelo mundo, e é quase uma garantia de comunicação.

Também pelo fato de o inglês ser hoje, praticamente, uma língua "padrão" no mundo, acho que seu aprendizado é necessário. Acredito que hoje, para uma pessoa de classe média, média alta, alta, que almeje um cargo profissional elevado, ou crescer profissionalmente, não saber falar inglês seja o mesmo que ser analfabeto

EL SD7. Na verdade não sei o que significa falar hebraico. Mas com certeza saber falar inglês, espanhol significa muito para mim. Amo de paixão falar inglês, eu acho a língua mais linda desse mundo, fora que é uma língua universal que é obrigação de todos saberem falar inglês.

EL SD8. Para mim é uma das línguas de identidade com o judaísmo e com o sionismo, além de ser um idioma a mais. Há pessoas que te admiram por saber falar uma língua em que até os caracteres são diferentes. Saber outras línguas significa que eu tenho liberdade de pelo menos poder me comunicar com outras pessoas do mundo, mesmo que seja virtualmente em uma viagem, num estudo. Além disso, conforme o país que você está isso lhe garante certa receptividade, como exemplo na França (segundo a fama - risos), eles gostam quando as pessoas falam a língua-pátria. Saber outra língua, também me ajuda quando vou ler um texto em outro idioma. 


\section{ANEXO 5 - Respostas Professores}

\section{A. Professores de Língua Hebraica e /ou Cultura judaica.}

1. Anos de magistério (20)

2. Sou professor de Língua Hebraica (x) Cultura Judaica (x) Tanach (x)

3. Faixa etária para a qual leciona: Jardim de infância ( )

4. Fundamental I (x) Ensino Fundamental II (x)

5. Ensino Médio ( ) Ensino Superior ( )

Cite seu histórico escolar: Estudei no Colégio Iavne da 1 serie( E.F) ao final do Ensino Médio e Estudei Psicologia na Faculdade "São Marco"

Nome da Instituição em que estudou: Iavne - Beit Chinuch

Cite o nome das demais instituições que trabalhaste como professor. Colegio Iavne

1. Qual é a importância que você atribui ao aprendizado do hebraico como matéria regular na formação do seu aluno?

A Língua Hebraica como qualquer outra língua estrangeira é importante, pois amplia os horizontes,fortalece a cultura e o hebraico em particular para alunos que queiram estudar mais profundamente a Torah (Bíblia sagrada).

2. E qual é a importância no atual contexto histórico de aprender outras línguas para seu aluno. (Inglês, espanhol, francês etc).

Dada a velocidade de informações mais acelerada, a interação entre os povos e as facilidades de intercambio entre eles, ter o conhecimento de varias línguas prepara o estudante para viver melhor na sociedade atual.

3. Quais são os materiais didáticos que você utiliza no ensino-aprendizagem da língua hebraica em sua sala de aula? E em que medida os livros adotados pela escola são adequados para alcançar os objetivos propostos na aprendizagem?

Utilizo em minhas aulas de recursos áudio-visuais e livros didáticos. Os livros ajudam muito na medida em que estimulam a aprendizagem da linguagem oral e escrita. 
4. Quais são os principais obstáculos ou resistências que você percebe no contexto escolar ao ensinar a língua hebraica como matéria regular no currículo? (da escola e suas como professor).

Por não ser a língua nativa requer um empenho maior do professor que necessita ter uma experiência didática maior do processo de ensino da língua e do programa a ser ensinado.

5. Aponte as dificuldades dos alunos na aprendizagem do hebraico como língua estrangeira?

Por ser a segunda língua e não a língua nativa há alunos com maior e menor dificuldade, além do fato do hebraico não ser entre as línguas estrangeiras a mais praticada.

\section{B. Professores de Língua Hebraica e /ou Cultura judaica.}

\section{Anos de magistério ( 34 )}

2. Sou professor de Língua Hebraica ( ) Cultura Judaica ( ) Tanach ( )

3. Faixa etária para a qual leciona: Jardim de infância ( )

4. Fundamental I ( ) Ensino Fundamental II (x)

5. Ensino Médio ( ) Ensino Superior ( )

Nome das instituições em que estudaste

Colégio Renascença, Universidade de Jerusalém, Unifesp (especialização - não na área de Judaísmo).

Nome das instituições que trabalhaste como professor/a.

Iavne, Renascença, Bialik (Ensino Infantil).

1. Qual é a importância que você atribui ao aprendizado do hebraico como matéria regular na formação do seu aluno?

Em minha opinião o Ensino de Língua Hebraica é estruturante na formação judaica de nosso aluno. Através desta, o jovem se conecta e constitui elo com o Estado de Israel atual; permite o acesso à liturgia em sua forma original (hebraico) que o possibilitará viver judaico (leitura sidur, Tora, etc). 
2. E a importância no atual contexto histórico de aprender outras línguas para seu aluno. (Inglês, espanhol, francês etc.).

Hoje vivemos num mundo globalizado no qual não existem mais "fronteiras" a nível cultural, econômico e tecnológico. O viver em tempo real apoiados na área digital nos leva a considerar a aprendizagem de idiomas fundamental para viver estes tempos. $\mathrm{O}$ inglês se torna "uma segunda língua" necessária a todos e a aprendizagem de outros idiomas, ex mandarin, espanhol, alemão, etc se tornam cada dia mais necessários para se diferenciar ao acesso às ofertas de emprego trabalho.

3. Quais são os materiais didáticos que você utiliza no ensino-aprendizagem da língua hebraica em sua sala de aula? $\mathrm{E}$ em que medida os livros adotados pela escola são adequados para alcançar os objetivos propostos na aprendizagem?

Um dos grandes desafios de nossa prática é o material de apoio didático para o trabalho de Língua Hebraica. Como utilizamos o enfoque comunicativo em nosso trabalho, não são muitas as opções, adotamos os livros: Ivrit Mibereshit e Ivrit Meatrachalá no Ciclo do Fundamental II. Como complemento, usamos os recursos da informática, através de sites especializados e programas em cds. O trabalho com músicas e jornais completa o trabalho.

4. Quais são os principais obstáculos ou resistências que você percebe no contexto escolar ao ensinar a língua hebraica como matéria regular no currículo? (da escola e suas como professor).

-Falta de professores qualificados e materiais.

-Diminuição de carga horária na grade curricular

\section{E quais são as dificuldades que você enfrenta como professor em sua prática de} ensino?

A não valorização do aprendizado da Língua Hebraica por parte dos pais, estes se preocupam mais com o ensino do judaísmo e não com a aprendizagem da língua hebraica. Alunos em fase de adolescência que não reconhecem e não significam a aprendizado da Língua Hebraica. Estes vivem um período natural de questionamentos e a Língua Hebraica neste momento não faz sentido para eles. 
6. Aponte as dificuldades dos alunos na aprendizagem do hebraico como língua estrangeira?

-Carência de professores especializados para a Educação Formal, em médio prazo entrará em colapso.

- Falta de instituição em São Paulo/ Brasil para a formação de professores

- Falta de materiais adaptados às necessidades regionais. 